\title{
Provenance and tectonic setting of the Paleozoic Tamatán Group, NE Mexico: Implications for the closure of the Rheic Ocean
}

\author{
Juan Moisés Casas-Peña ${ }^{\mathrm{a}}$, Juan Alonso Ramírez-Fernández ${ }^{\mathrm{b}}$, Fernando Velasco-Tapia ${ }^{\mathrm{b}}$, \\ Eduardo Alejandro Alemán-Gallardo a , Carita Augustsson ${ }^{\mathrm{c}}$, Bodo Weber ${ }^{\mathrm{d}}$, Dirk Frei ${ }^{\mathrm{e}}$, Uwe Jenchen ${ }^{\mathrm{b}, *}$

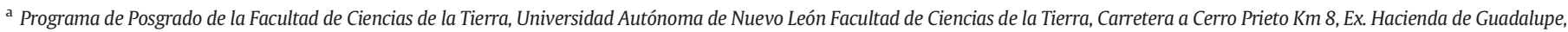 \\ Linares, N.L. 67700, Mexico \\ ${ }^{\mathrm{b}}$ Facultad de Ciencias de la Tierra, Universidad Autónoma de Nuevo León, Carretera a Cerro Prieto Km 8, Ex. Hacienda de Guadalupe, Linares, N.L. 67700, Mexico \\ c Faculty of Science and Technology, Department of Energy Resources, Universitetet $i$ Stavanger, Stavanger 4036, Norway \\ ' Departamento de Geología, Centro de Investigación Científica y de Educación Superior de Ensenada (CICESE), Ensenada, Mexico \\ e Department of Earth Sciences, University of the Western Cape, Cape Town, South Africa
}

\section{A R T I C L E I N F O}

\section{Article history:}

Received 8 June 2020

Received in revised form 2 November 2020

Accepted 15 December 2020

Available online 7 January 2021

\section{Keywords:}

Paleozoic

Tamatán Group

Petrography

Geochemistry

Geochronology

$\mathrm{U}-\mathrm{Pb}$ detrital zircon age

Provenance analysis

\begin{abstract}
A B S T R A C T
The Huizachal-Peregrina Anticlinorium in northeastern Mexico comprises a wide variety of Precambrian and Paleozoic basement units. In this work, Silurian-to-Permian unmetamorphosed siliciclastic successions (i.e., Cañón de Caballeros, Vicente Guerrero, Del Monte, and Guacamaya formations) forming the Tamatán Group is described; the group overlies the Novillo metamorphic complex, which is the northernmost exposed region of the Oaxaquia microcontinent. In this paper, a provenance model for the Tamatán Group is proposed based on new petrological data, whole-rock geochemical data, and $\mathrm{U}-\mathrm{Pb}$ LA-ICP-MS detrital zircon age data from these marine fossiliferous strata. The results show a shallowmarine to deep-water clastic succession classified as feldspatho-lithic-quartzose and litho-feldspathoquartzose (Cañón de Caballeros and Vicente Guerrero formations) and feldspatho-quartzo-lithic and litho-quartzo-feldspathic (Del Monte and Guacamaya formations). The petrological and geochemical data indicate a derivation from felsitic, intermediate, and basic rocks, intense to moderate weathering, and high to moderate recycling of the source area. The geochronological data can be organized into three main detrital zircon $\mathrm{U}-\mathrm{Pb}$ age groups: (1) a Meso-Neoproterozoic group, likely derived from Oaxaquia and the Maya block, which is also the probable source of 1.5-1.6 Ga zircon grains; (2) an Ordovician-Silurian group that is likely sourced by igneous Maya Block intrusions or from local units such as the Ordovician Peregrina Tonalite; and (3) Pennsylvanian and Permian zircon that can be derived from magmatic arc-related intrusions from the diachronous Rheic closure. Additionally, major, trace, and rare earth element concentrations and ratios from the Tamatán Group indicate a passive margin that evolved into magmatic arc sources within the upper continental crust. The integration of our data indicates that the Tamatán Group was deposited in an unreported back-arc basin from the northernmost part of Oaxaquia near the Maya Block along the northwestern Gondwanan margin during the closure of the Rheic Ocean priori to complete Pangea.
\end{abstract}

(c) 2020 International Association for Gondwana Research. Published by Elsevier B.V. All rights reserved.

\section{Introduction}

Northeastern Mexican Paleozoic sedimentary basins are underrepresented in the paleogeographic reconstructions (e.g., Campa and Coney, 1983; Sedlock et al., 1993; Dickinson and Lawton, 2001) of Mexico due to data scarcity. One of these basins is represented by the

\footnotetext{
* Corresponding author at: Facultad de Ciencias de la Tierra, Universidad Autónoma de Nuevo León, Carretera a Cerro Prieto Km 8, Ex. Hacienda de Guadalupe, Linares, N.L. 67700, Mexico.

E-mail address: uwe.jenchen@uanl.edu.mx (U. Jenchen).
}

Paleozoic strata of the Tamatán Group near Cd. Victoria, Tamaulipas. The Tamatán Group, comprising the Silurian Cañón de Caballeros Formation and the Carboniferous to Permian Vicente Guerrero, Del Monte, and Guacamaya Formations, overlies the crystalline basement of the Huizachal-Peregrina Anticlinorium. Together, they conform the basement of the Sierra Madre/northern Oaxaquia terrane (OrtegaGutiérreza et al., 2018; Fig. 1). This basement represents the most complete suites of Precambrian metamorphic, and Paleozoic metamorphic, magmatic, and sedimentary rocks in northeastern Mexico (e.g., Barboza-Gudiño et al., 2011). The position of the Tamatán Group can be related to adjacent Mexican peri-Gondwanan terranes, which 


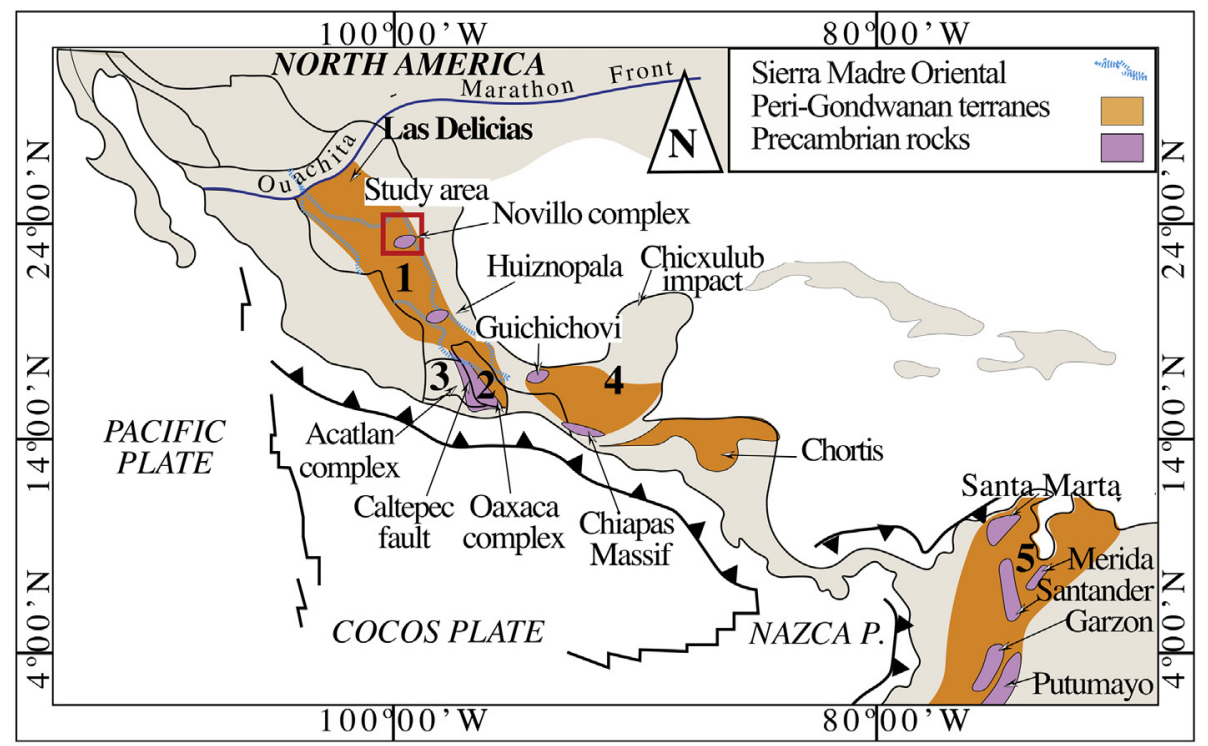

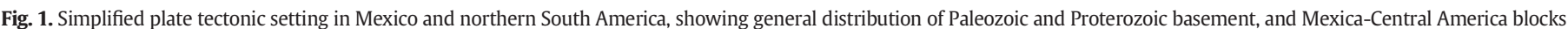

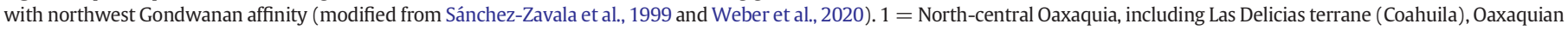

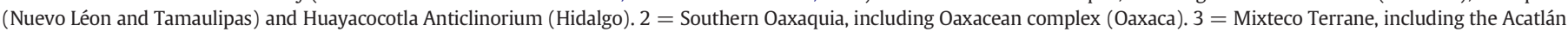

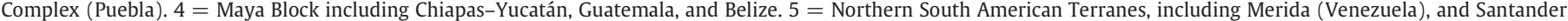
Massif (Colombia).

may be related to Paleozoic rocks in central-southern Mexico as well as Venezuela-Colombia terranes in northern South America. Several authors (e.g., Talavera-Mendoza et al., 2005; Rosales-Lagarde et al., 2005; Weber et al., 2006; Martens et al., 2010; van der Lelij et al., 2016; Fig. 2) described in Southern Mexico terranes, such as the Mixteca-, southern Oaxaquia-, and Maya-Terrane, adyacent to the northern Gondwanan margin, which were shuffled along the Laurentia margin during early Paleozoic subduction phases. Thus, the subsequent migration toward Laurentia may also constrain the interaction between Laurentia and peri-Gondwanan terranes during the Paleozoic and the paleogeographic evolution and closure of the Rheic Ocean. The paleontological record of the Paleozoic Tamatán Group indicates that the oldest succession (Cañón de Caballeros Formation) evolved along the northwestern Gondwanan border during the Early Paleozoic (Stewart et al., 1999). The younger ones were closer to Laurentia, documented by the presence of North American realm fauna (Boucot et al., 1997) in the Late Paleozoic. However, to date, there have been no studies on its provenance or tectonic setting.

In this paper, we present new information including modal petrography, the first whole-rock geochemical analysis from the sedimentary units, and $\mathrm{U}-\mathrm{Pb}$ detrital zircon ages of coarse-grained sandstones from the Tamatán Group. Data analysis has permitted the provenance of these rocks to be inferred, with tectonic implications for these clastic systems. We propose a new configuration model for the northwestern margin of Gondwana during the Middle to Upper Paleozoic.

\section{Geological setting}

The plate tectonic setting in Mexico and northern South America is characterized by several Proterozoic, Paleozoic, and Paleozoic sedimentary units as well as Mexican-Central America blocks with northwest Gondwanan affinity (Sánchez-Zavala et al., 1999; Weber et al., 2020), which comprise 1) north-central Oaxaquia, including Las Delicias terrane (Coahuila), northern Oaxaquia (Nuevo Léon and Tamaulipas) and Huayacocotla Anticlinorium (Hidalgo); 2) southern Oaxaquia (Oaxaca); 3) Mixteco Terrane, including the Acatlán Complex (Puebla); 4) the Maya Block including Chiapas-Yucatán, Guatemala and Belize, and 5) the northern South American Terranes, including Merida (Venezuela) and Santander Massif (Colombia) (Fig. 1 and Fig. 2).

\subsection{Sierra Madre/Northern Oaxaquia}

Pre-Mesozoic rocks in northeastern Mexico document the geologic history of the region from Proterozoic Grenvillian age to the formation of Pangea during Permian-Triassic. These rock sequences are located in only a few outcrop areas and are spatially separated by the coverage of huge deposits of Mesozoic and Cenozoic age. Additionally, metamorphic processes resulting from deformation events in the Proterozoic, Paleozoic, and Mesozoic have influenced some localities (Flawn and Diaz, 1959; Cunningham, 1975; Centeno-García, 2005).

Paleozoic outcrops of the Las Delicias Formation are bounded in the south by the Coahuila marginal folded belt and in the north by the San Marcos fault, yet neither footwall nor hanging wall limits have been reported. For example, most upper boundaries consist of discordant contact with the overlying Las Uvas Formation and Lower Cretaceous limestones. McKee et al. (1999) divided the Las Delicias Formation into eleven Late Mississippian-Permian lithosomes.

In the Aramberri and Miquihuana uplifts, the Granjeno Complex is most widely exposed (Carrillo-Bravo, 1961; Torres-Sánchez et al., 2016) and is composed of greenschist facies metasedimentary and metaigneous rocks, including the massive and irregular Victoria serpentinite body (Ramírez-Fernández and Jenchen, 2016; TorresSánchez et al., 2017). The Granjeno Complex has been interpreted as part of an accretionary unit (Granjeno-Acatlán Complex, former Sierra Madre Terrane; Keppie, 2004; Barboza-Gudiño et al., 2011), including the obducted oceanic crust (Victoria Serpentinite) from an active margin of Gondwana during the Carboniferous.

In the deeply eroded tectonic windows of the Sierra Madre Oriental, Precambrian and Paleozoic units crop out in the Huizachal-Peregrina Anticlinorium:

- The Novillo metamorphic complex consists of (i) a metaigneous suite subdivided into the Old Suite (1235-1115 Ma; Cameron et al., 2004), including felsitic gneiss, metagranites, mafic, and migmatitic gneiss, and the younger "AMCG Suite" (anorthosite, mangerite, charnockite, granite), dated at 1035-1010 Ma (Cameron et al., 2004). (ii) A 


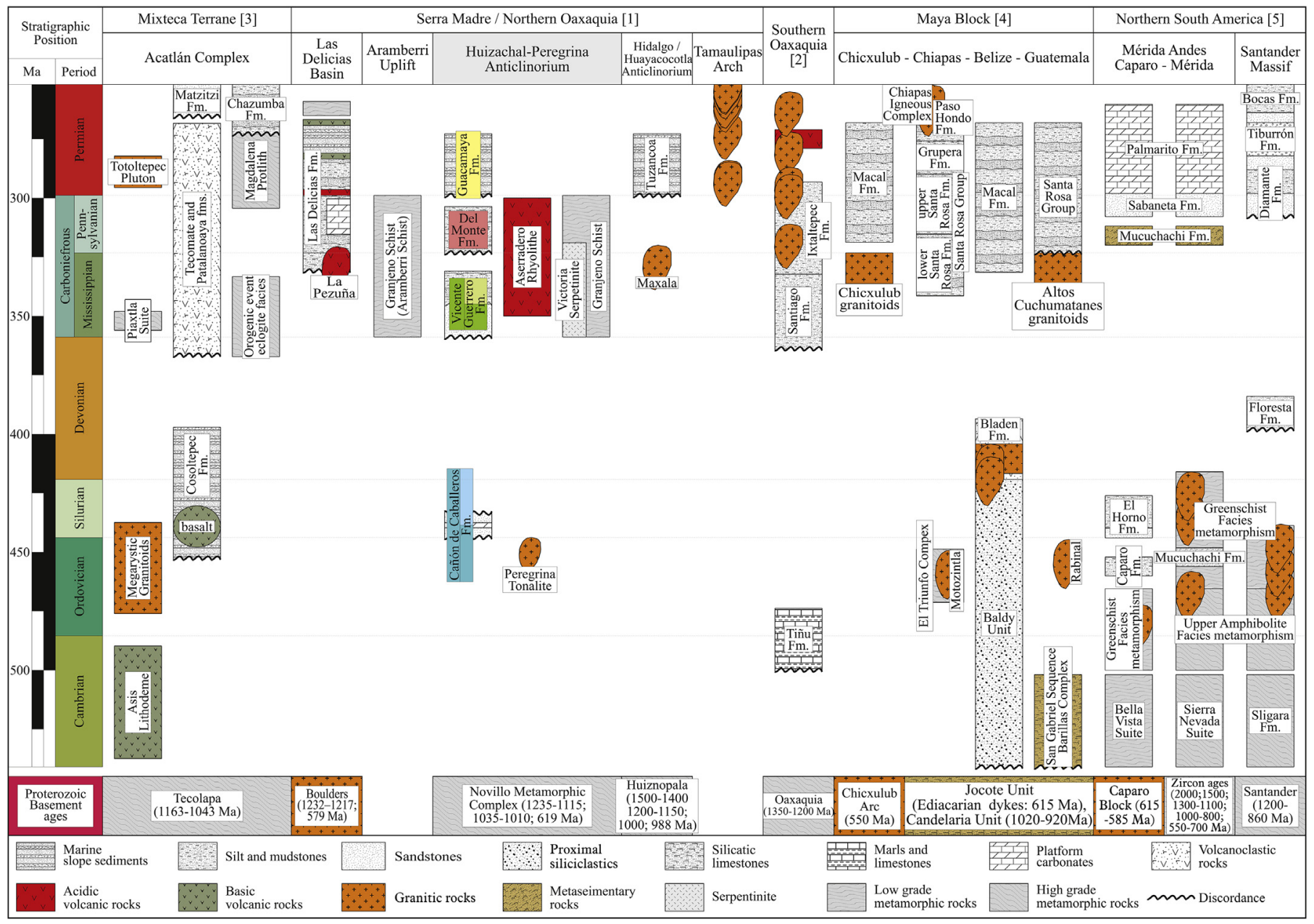

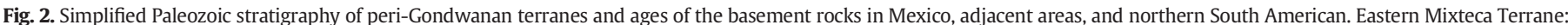

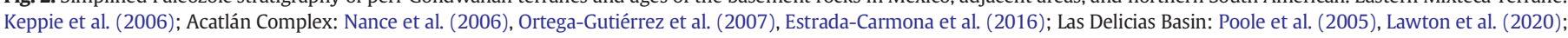

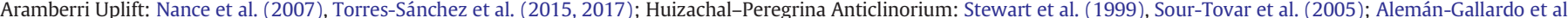

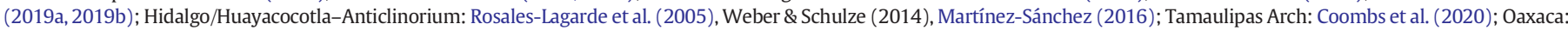

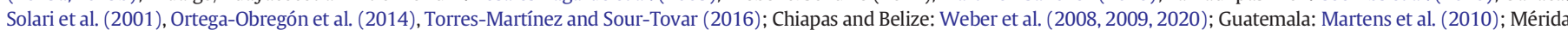
Andes and Santander Massif: van der Lelij et al. (2016); Tazzo-Rangel et al. (2018).

metasedimentary suite composed of meta-arkose-anphibolite intercalations and calcsilicate marble. Both units of the Novillo metamorphic complex are considered part of the Oaxaquia microcontinent (Ortega-Gutiérrez Ortega-Gutiérrez, 1978; Keppie, 2004; Trainor et al., 2011) and metamorphosed during the Zapotecan phase (990 Ma), related to the Rodinia assemblage (Solari et al., 2003; Cameron et al., 2004; Alemán-Gallardo et al., 2019b). These rocks have also been intruded by rift-related, subvolcanic, basaltic (E-MORB) dykes, yielding an early Ediacaran age (approximately $619 \mathrm{Ma}$; Weber et al., 2019). The latter are related to the Rodina breakup and the onset of the opening of the Iapetus Ocean. The Novillo Complex has tectonic contact with the potentially early Carboniferous Granjeno Complex (Carrillo-Bravo Carrillo-Bravo, 1961; Trainor et al., 2011).

- The Granjeno Complex crops out on the borders of the core of the Huizachal-Peregrina Anticlinorium (Fig. 1) and comprises low-grade metamorphic poly-assemblies including metasedimentary rocks (e.g., metapsammite and metapelite; Barboza-Gudiño et al., 2011), metavolcanic clastic units (e.g., metatuff, meta-flow, and metapillow lava), and a serpentinized ultramafic unit (Victoria Serpentinite; Torres-Sánchez et al., 2017; (Fig. 1). In the Aramberri and Miquihuana uplifts, the Granjeno Complex is most widely exposed (Carrillo-Bravo, 1961; Nance et al., 2007; Barboza-Gudiño et al., 2011; Torres-Sánchez et al., 2015, 2016). Metamorphism is dated at $300 \mathrm{Ma}$ (Dowe et al., 2005; Nance et al., 2007) and is associated with an obducted accretionary prism resulting from convergence along the western Gondwanan margin (Torres-Sánchez et al., 2015).

- The Ordovician Peregrina Tonalite, is exposed in the Novillo, Peregrina, and Caballeros canyons (Fig. 1; Alemán-Gallardo et al., $2019 b$ ). Its zircon U-Pb age is $449 \pm 3 \mathrm{Ma}$ (Katian stage; AlemánGallardo et al., 2019b). This tonalitic pluton has been associated with the Famatinian Magmatic Arc in South America (Chew et al., 2007), which is termed the Peregrina-Motozintla Arc in Mexico (EstradaCarmona et al., 2012; González-Guzmán et al., 2016; AlemánGallardo et al., 2019b). A close relationship between the Tamaulipas (former Sierra Madre Terrane) and the southern Maya block (Chiapas, NW Guatemala, Belize) is therefore suggested.

- The Tamatán Group consists of non-metamorphic sedimentary deformed strata and comprises the Cañón de Caballeros, Vicente Guerrero, Del Monte, and Guacamaya formations (following Stewart et al., 1999). It was informally named by Alemán-Gallardo et al. (2019a) as the Tamatán succession. Fossil fauna in these sedimentary strata indicates a depositional age of Silurian to Permian (Boucot et al., 1997; Stewart et al., 1999), with a major hiatus during the Devonian. 


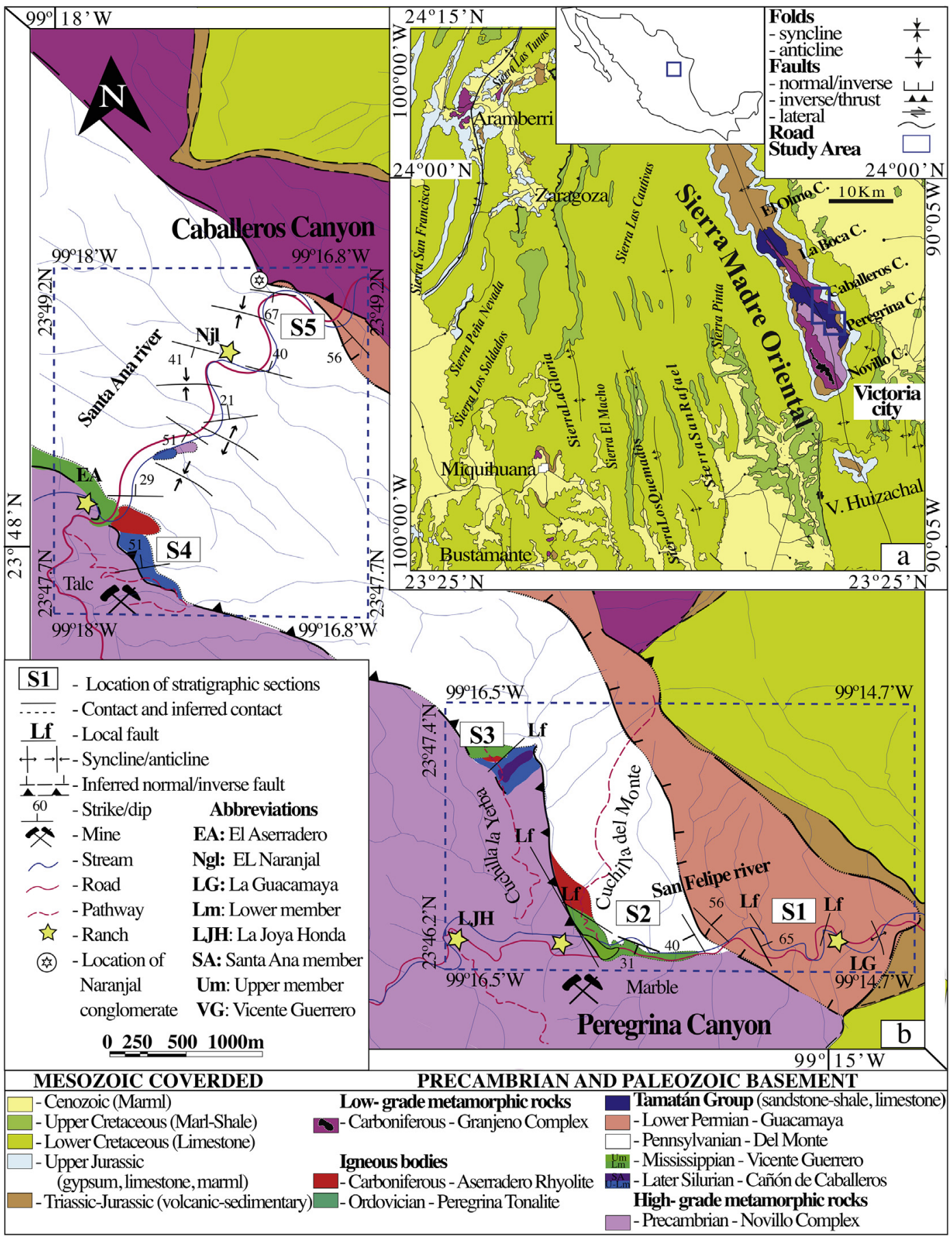

Fig. 3. Geological map of the study area (modified from Ramírez-Ramírez, 1992; Stewart et al., 1999). Blue dashed boxes indicate the study areas.

- Additionally, the Tamatán Group contains banded felsite flows termed the Aserradero Rhyolite (Stewart et al., 1999) with unclear contacts to the Vicente Guerrero and Del Monte formations (Gursky, 1994; Stewart et al., 1999; (Fig. 3). The Aserradero Rhyolite exhibits two fabrics: (i) a weak porphyritic texture with quartz, feldspar, and muscovite distributed within a very fine crystalline groundmass; and (ii) phenocrysts of quartz, alkaline feldspar, and very rare plagioclase and biotite. Detrital zircon U-Pb ages are $334 \pm 34$ Ma (Stewart et al., 1999). The Aserradero Rhyolite has been interpreted as a part of a Carboniferous arc along the western margin of Pangea (Kirsch et al., 2012).
Finally, in the Huayacocotla Anticlinorium (Hidalgo state), the basement consists of the Huiznopala Gneiss, granulite facies metamorphic rocks, and igneous intrusions of Meso-Neoproterozoic ages, which can be interpreted as analogous to the Novillo Complex (Weber and Schulze, 2014), and Carboniferous igneous intrusions of the Maxala granite (Martínez-Sánchez, 2016). This unit is covered by the Tuzancoa Formation, a Permian volcano-sedimentary succession with abundant andesitic and basaltic intercalations, which is considered to be equivalent to the Guacamaya Formation (Rosales-Lagarde et al., 2005; Fig. 2). 


\subsection{Oaxaca complex (Southern Oaxaquia)}

The Oaxaca complex corresponds to the southmost part of Oaxaquia, including high-grade metamorphic rocks with an age of $990 \mathrm{Ma}$, with granitic intrusions ( 1.14-1.11 Ga) and AMCG rocks ( 1.01 Ga; Solari et al., 2003). Together with the Novillo and Huiznopala complexes, the Oaxaca Complex has been interpreted as an allochthonous microcontinent of North America during the Precambrian-Early Paleozoic evolution (e.g., Ortega-Gutiérrez et al., 1995; Fig. 2). The Paleozoic sedimentary successions discordantly overlay the Oaxaca Complex, including limestone, siltstone, shale, and minor sandstones, which are considered marine deposits from the Cambrian-Ordovician Tiñu Formation, the Mississippian Santiago Formation, and Pennsylvanian Ixtaltepec Formation (Gillis et al., 2005; Fig. 2). Some authors (including Navarro-Santillán et al., 2002; Sour-Tovar and MartínezChacón, 2004) documented that the Mississippian Santiago (Oaxaca), Patlanoaya (Puebla), and Vicente Guerrero (Tamaulipas) formations show similar Mississippian brachiopods, whereas the Ixtaltepec Formation contains abundant Pennsylvanian fauna, including brachiopods and radiolaria. Both units are related to North American species (TorresMartínez and Sour-Tovar, 2016). The detrital provenance of this formation indicates a pronounced derivation from the local Oaxaca complex according to $\mathrm{U}-\mathrm{Pb}$ detrital zircon age at $\sim 981 \mathrm{Ma}$ (Gillis et al., 2005). Correlations with the Mississippian Vicente Guerrero and the Pennsylvanian Del Monte formations are plausible. In addition, igneous intrusions exposed in the Oaxacan complex, such as Cuanana pluton (ca. $311 \mathrm{Ma}$ ), the Honduras batholith (ca. $290 \mathrm{Ma}$; from the Juchatengo Igneous Complex), the Zaniza Batholith (ca. $287 \mathrm{Ma}$ ), La Carbonera Stock (ca. $272 \mathrm{Ma}$ ), and the Etla Granite (ca. $255 \mathrm{Ma}$ ), are all interpreted as associated with a continental arc and to the closure of the Rheic Ocean prior or during the assembly of Pangea (e.g., Ortega-Obregón et al., 2014; Fig. 2).

\subsection{Mixteca Terrane}

The Mixteca terrane is juxtaposed on the western side of the Oaxacan Complex (Fig. 1). The basement is represented by the Acatlán complex, a lithotectonic complex with Ordovician to Permian deposits associated with ocean floor crust, trench turbidites, and reworked Proterozoic crust (Keppie et al., 2008). The Acatlán complex is limited to the east by the Caltepec fault (Estrada-Carmona et al., 2012) and divided into two major groups.

- The Petalcingo group is composed of three units, the low- to highgrade metamorphic rocks from the Magdalena and Chazumba formations, which are considered as clastic wedges (Keppie et al., 2006), and the Cosoltepec Formation, which includes phyllites and quartzites with minor mafic intercalations whose depositational ages range from Ordovician to Lower Devonian (e.g., Talavera-Mendoza et al., 2005; Keppie et al., 2007).

- The Piaxtla suite consists of metasedimentary rocks locally with eclogites (Keppie et al., 2006).

Both groups are unconformable overlain by the CarboniferousLower Permian Tecomate and Patlanoaya formations that include siliciclastic and volcano-siliciclastic rocks, which can be, according to the fauna, correlated with the fauna of the Mississippian Del Monte Formation (Fig. 2; Esquivel-Macías et al., 2004). The latest Paleozoic sedimentary rocks are formed by alluvial deposits from the Matzitzi Formation (Centeno-García et al., 2009). A contemporaneous age to the Guacamaya Formation, but in a quiet different depositional environment, as suggested by Vachard et al. (2004). The igneous rocks of the Esperanza megacrystic granite $(440 \pm 14 \mathrm{Ma}$; Talavera-Mendoza et al., 2005), the La Noria Granitoid ( $371 \pm 34$ Ma; Yañez et al., 1991; Miller et al., 2007) and the Totoltepec Plutons ( $287 \pm 2 \mathrm{Ma}$ ) are also exposed to this complex (Kirsch et al., 2013; Fig. 2).

\subsection{Maya Block}

The Maya block includes the Yucatan Peninsula, parts of the coastal plain of the Gulf of México and southeastern México from the Tehuantepec Isthmus to Chiapas, northwestern Guatemala and Belize. Different pre-Mesozoic exposures comprise the basement of the Maya Block. (1) West of the Tehuantepec Isthmus, the Guichicovi Complex (Weber and Köhler, 1999; Weber et al., 2010) contains 1.25-1.2 Ga igneous protoliths, AMCG suite rocks and metasedimentary sequences, altogether metamorphosed to granulite facies at 990-980 Ma. The Guichicovi Complex is indistinguishable from the Oaxacan Complex and other Oaxaquia exposures. (2) East of the Tehuantepec Isthmus Mexico's largest Permian batholith forms most of the Chiapas Massif (e.g. Damon et al., 1981). Precambrian to Paleozoic basement inliers as well as abundant ca. 1.0 Ga inherited zircon in the batholithic rocks indicate unexposed Precambrian basement and crustal anatexis forming the Permian granitoids (Weber et al., 2006, 2007). (3) Along the southeastern edge of the Chiapas massif, Late Meso- to Neoproterozoic gneisses and amphibolites of the Candelaria Unit (1.02-0.91 Ga; Estrada-Carmona et al., 2012; Weber et al., 2018) and coeval massiftype anorthosites suite rocks (Socunusco -Mariscal anorthosite; Cisneros de León et al., 2017) comprise the metaigneous basement of the El Triunfo Complex. The metasedimentary Jocote Unit of Ediacaran age (González-Guzmán et al., 2016) discordantly overlays the Candelaria Unit (Weber et al., 2008, 2018). Rift-related (E-MORB) dykes intruded both metaigneous and metasedimentary basement rocks at ca. $615 \mathrm{Ma}$ (Weber et al., 2020). The El Triunfo Complex stands out by Ordovician medium- to high-grade metamorphism, anatexis and the intrusion of the Motozintla plutonic suite ( $480-450$ Ma; EstradaCarmona et al., 2012; González-Guzmán et al., 2016; Weber et al., 2018). (4) Similar Ordovician plutons of the Rabinal granite suite (462-453 Ma; Ortega-Obregón et al., 2008) and the Altos Cuchumatanes (461 Ma; Solari et al., 2010), both in central Guatemala, intruded an older, metasedimentary basement. (5) Silurian to earliest Devonian (420-400 Ma) granitic plutons (Mountain Pine Ridge) and rhyolitic volcanic rocks (Bladen volcanic member) of the Maya Mountains in Belize (Steiner and Walker, 1996; Martens et al., 2010; Weber et al., 2012) represent the latest stage of Early Paleozoic arc magmatism in the Maya Block. This semi-continuous Ordovician-Silurian magmatic belt (Estrada-Carmona et al., 2012) was probably connected with coeval Ordovician plutonic rocks in Tamaulipas, and it is interpreted as the northeastern extension of the Early Paleozoic Famatinian belt (Weber et al., 2018; Aleman-Gallardo et al., 2019a; Fig. 2). (6) The Yucatán Peninsula is mainly composed of Cretaceous successions. Its crystalline basement is only known from Chicxulub ejecta suggesting 545 Ma granitic basement (Krogh et al., 1993a, 1993b; Keppie et al., 2011) and from a borehole on the peak ring of the Chicxulub crater that drilled into a 326 Ma granitic pluton (Zhao et al., 2020). Similar, Carboniferous igneous rocks are known only from the Altos Cuchumatanes, Guatemala ( $317 \mathrm{Ma}$; Solari et al., 2010) and they are interpreted in terms of the onset of convergence and subduction of the Rheic Ocean beneath northern Gondwana prior to its collision with Laurentia (Zhao et al., 2020).

Early Paleozoic sedimentary rocks dominate the Maya Mountains (Belize), namely the Baldy Unit (Cambrian-Ordovician?) and the volcaniclastic Bladen Formation ( 406 Ma; Martens et al., 2010). The Baldy Unit possibly correlates with similar metasedimentary sequences in northern Guatemala (San Gabriel sequence and Barillas complex; Ortega-Gutiérrez et al., 2007). Similar to the Ediacaran Jocote unit, the Baldy unit contains - besides abundant 1.2-0.9 Ga zircon - a significant number of 1.6-1.5 Ga detrital zircon grains, uncommon for Oaxaquia (Weber et al., 2008; Martens et al., 2010).

After a Devonian hiatus, Mississippian-Early Permian siliciclastic succession and fossiliferous limestones of the Santa Rosa, the Grupera, and Paso Hondo formations, crop out in eastern Chiapas (HernándezGarcía, 1973) and northern Guatemala (Clemons and Burkart, 1971). The flysch-type Santa Rosa Formation in Chiapas (Santa Rosa Group in 
Guatemala) contains a wide range of detrital zircons from Achaean to Carboniferous ( $340-325$ Ma youngest detrital zircon grains) but most zircon grains indicate sources related to Pan-African-Brasiliano type orogens (Weber et al., 2006, 2009). In the Maya Mountains, the contemporaneous conglomerates and sandstones of the Macal Formation contains mostly local detritus from the Mountain Pine Ridge granites (Martens et al., 2010). A temporal correlation has been observed between the Upper Paleozoic Santa Rosa Group in Guatemala and the Del Monte and Guacamaya formations in Tamaulipas (Fig. 2).

\subsection{Northern Andes}

The Venezuelan Andes, which include the Merida and Caparo localities, show an Ediacaran-Cambrian basement ( 520 Ma; van der Lelij et al., 2016), consisting of high- to low-grade metamorphic rocks. The basement includes amphibolite and greenschist facies from the Iglesias Complex (Sierra Nevada-, Bella Vista-, and Tostos suites; González González de Juana et al., 1980; Bellizzia and Pimentel, 1994; TazzoRangel et al., 2018). The Iglesias complex is intruded by OrdovicianSilurian granitoids (van der Lelij et al., 2016) and is overlain by Ordovician and Pennsylvanian metasedimentary and sedimentary successions from the Caparo- and Mucuchachí formations, which are interlayered by felsite rocks (Bellizzia and Pimentel, 1994). Clastic and carbonate rocks with abundant Silurian fossils from the El Horno Formation (Boucot et al., 1999) document a fauna similar to the Cañón de Caballeros Formation. A remarkable hiatus between the Devonian and Mississippian deposits caused by tectonic compression and restricted marine circulation (González de Juana et al., 1980) has been documented. The Upper Paleozoic deposits are composed of siliciclastic and carbonate rocks intruded by Permian-Triassic felsitic and mafic rocks (Sabaneta and Palmarito formations; Laya and Tucker, 2012; Tazzo-Rangel et al., 2018; Fig. 2).

In Colombia, the Eastern Cordillera, also referred to as Chibcha Terrane (e.g., Bellizzia and Pimentel, 1994), includes the Quetame Massif, the Santander Massif, the Floresta, Santa Marta, and Colombian Perijá Mountains. The outermost Precambrian units outcrop in the Santander Massif and Santa Marta Mountains, consisting of paragneisses, marbles, and migmatites from the Bucaramanga Gneiss basement ( $945 \pm 40 \mathrm{Ma}$; García et al., 2005; Urueña-Suárez and Zuluaga, 2011). The Bucaramanga gneiss is overlain by the Ordovician to Devonian Silgará Formation, formed phyllites, quartzites, and metasiltstones, intruded by igneous rocks. The first metamorphism occurred prior to the Middle Devonian (García et al., 2005). The Paleozoic sedimentary rocks from the Middle Devonian Floresta Formation comprise marine sedimentary rocks that uncomfortably overlay the Silgará Formation. These formations, together with the overlying Late Carboniferous Diamante Formation, are metamorphosed under low-grade conditions, different from the basement, metamorphism appears to be related to a different event that predates the deposition of the younger Tiburón and Bocas formations (e.g., Vinasco et al., 2006; Cochrane et al., 2014; Spikings et al., 2015; van der Lelij et al., 2016; Tazzo-Rangel et al., 2018; Fig. 2), whereas the sedimentary cover is associated with several marine cycles, developed as deep- and shallow-marine even deltaic deposits in a pericratonic foreland basin during the closure of the Rheic Ocean and the Pangea amalgamation (e.g., Laya and Tucker, 2012).

\section{Geological background}

The Huizachal-Peregrina Anticlinorium is located in the northwest of Ciudad Victoria, Tamaulipas. It covers an area of $35 \mathrm{~km}^{2}$ and is aligned northwest-southeast (Fig. 3). The Huizachal-Peregrina Anticlinorium is the result of two Mesozoic deformation events: an early thin-skinned and second thick-skinned deformation that controlled the uplift and basement exposure (Zhou et al., 2006; Fitz-Díaz et al., 2018). The different rock units within can be accessed most easily along the canyons that cut across the anticlinorium (e.g., the Caballeros, Peregrina, and Novillo canyons; Fig. 3).

The Tamatán Group is exposed along the central axis of the Huizachal-Peregrina Anticlinorium, being limited to the west by the metamorphic basement (the Novillo Metamorphic Complex; AlemánGallardo et al., 2019a) and to the east by Mesozoic sedimentary cover and the Granjeno Complex (Fig. 3).

The Paleozoic sedimentary strata of the Tamatán Group were first described by Girty (1926) and latterly by Carrillo-Bravo, 1961. He defined seven sedimentary units formed by the La Presa Quartzite, Cañón de Caballeros Formation, Vicente Guerrero Formation, Naranjal Conglomerate, Del Monte Formation, Victoria Limestone, and Guacamaya Formation. The overall thickness of this succession in the Canyon Peregrina reaches 1600 m (Carrillo-Bravo, 1961; Gursky and Michalzik, 1989). Later, Ramírez-Ramírez (1992), Gursky (1994), and Stewart et al. (1999) redefined and merged the stratigraphy units proposing the following formations.

- The Silurian Cañón de Caballeros Formation is composed of conglomerates containing volcanic clasts, sandstones, and limestones with abundant Silurian fauna (Boucot et al., 1997) and has been deposited in marine shallow-water conditions (Stewart et al., 1999).

- The Lower Mississippian Vicente Guerrero Formation includes conglomerates, sandstones, and shales. Silty sandstones with abundant Mississippian brachiopods represent the oldest record of mixed faunas of South America and North America fossils (Stewart et al., 1999; Sour-Tovar and Martínez-Chacón, 2004).

- The Pennsylvanian Del Monte Formation, which unconformably overlays the Vicente Guerrero Formation, initiates with a basal conglomerate with large clasts of sandstones and black siltstones, previously referred as the Naranjal Conglomerate. The upper part is composed of bioclastic limestones with abundant quartz grains, sandstones, and siltstones. (Carrillo-Bravo, 1961; Ramírez-Ramírez, 1992). The Del Monte Formation has been interpreted as a product of turbidity flow units associated with proximal debris flows (Ramírez-Ramírez, 1992; Stewart et al., 1999).

- Banded felsite flows, termed as the Aserradero Rhyolite (Stewart et al., 1999), crop out in an unclear manner due to the dense local vegetation between the Vicente Guerrero and Del Monte formations. (Gursky, 1994; Stewart et al., 1999; Fig. 3).

- The Lower Permian Guacamaya Formation has been described as classical turbidites (flysch-type deposits) by Gursky and Michalzik (1989) and Stewart et al. (1999).

\section{Methodology}

\subsection{Field work}

Geological mapping was performed along the Santa Ana River in the Caballeros Canyon $\left(23^{\circ} 47.7^{\prime}-23^{\circ} 49.2^{\prime} \mathrm{N}\right.$, and $\left.99^{\circ} 16.8^{\prime}-99^{\circ} 18^{\prime} \mathrm{W}\right)$ and along the San Felipe River in the Peregrina Canyon $\left(23^{\circ} 46.2^{\prime}-\right.$ $23^{\circ} 47^{\circ} 0.4 \mathrm{~N}$ and $99^{\circ} 14.7-99^{\circ} 16.5 \mathrm{~W}$; Fig. 3). According to Tucker (2011), lithological characteristics as well depositional environments corresponding to each formation were described. The stratigraphic sections were measured based on the sections described in Carrillo-Bravo, 1961, Ramírez-Ramírez (1992), and Stewart et al. (1999). However, some outcrops expose high-deformation or massive strata (an example is shown in Fig. 5 in Casas-Peña et al., 2021). Thus, we denoted local parts from type-localities as well as the best exposed key-outcrops. In this study, we documented a total of $260 \mathrm{~m}$ from five local sections. Outcrops are shown in Figs. 3-7 (Casas-Peña et al., 2021). We collected 101 samples of coarse- to fine-grained sandstones-39 in the Caballeros Canyon and 62 in the Peregrina Canyon. The synthesis of the lithology and sample location is presented in Table 1 (of Casas-Peña et al., 2021). 

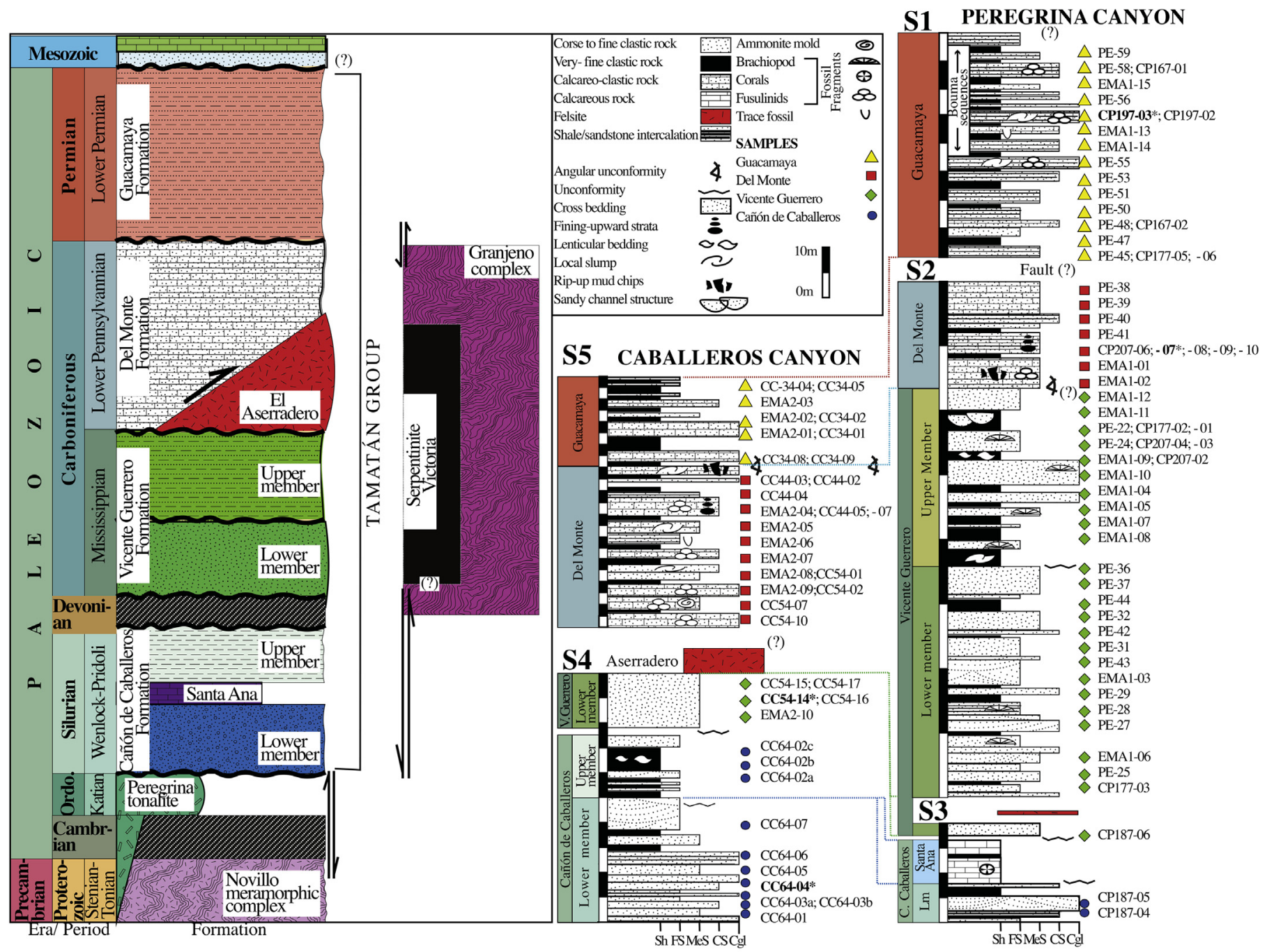

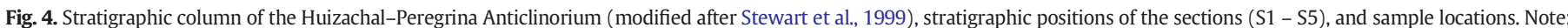
geochronological samples are highlighted with asterisk $\left({ }^{*}\right)$.

- Section 1 (S1,40 m) includes the Guacamaya Formation along the San Felipe River in the Peregrina Canyon.

- Section 2 (S2, 40) consists of the Lower and Upper members of Vicente Guerrero Formation and Del Monte Formation, around to Vicente Guerrero Ranch.

- Section 3 (S3, 20 m) corresponds to the Lower Member and Santa Ana Limestone of the Cañón de Caballeros Formation as well as the Lower member of the Vicente Guerrero Formation, which is exposed along the Cuchilla La Yerba path.

- Section 4 (S4,50 m) includes the Lower and Upper members from the Cañón de Caballeros Formation, outcropping along the road to the local talc mine, and the Lower Member of the Vicente Guerrero Formation about $\sim 400 \mathrm{~m}$ in the West of the Aserradero Ranch.

- Section 5 (S5; $110 \mathrm{~m}$ ) includes the Del Monte and Guacamaya formations. It is exposed along the Santa Ana River in the Caballeros Canyon.

\subsection{Sandstone petrography}

In total, 69 samples were used for petrographic analysis (Tables 1 to 5 ; Casas-Peña et al., 2021). The texture and composition of the framework components were analyzed using 300-600 points per thin section according to the Gazzi-Dickinson method (Ingersoll et al., 1984; Zuffa, 1985). Modal compositions were plotted in ternary diagrams based on
Garzanti (2016) and Garzanti (2018), modified from Ingersoll and Suczek (1979), Dickinson and Suczek (1979), Dickinson et al. (1983), and Dickinson (1985). Non-carbonate grains, microfossils, and bioclasts were counted as sedimentary lithic fragments; micas, opaque minerals, chlorite, heavy minerals, and the proto matrix phase were excluded from the petrographic plots. The $95 \%$ and $99 \%$ confidence intervals (Student's t-test; Borradaile, 2003) are shown in Fig. 6 and were plotted in distinct colour shades. More details concerning the recalculated and statistical parameters are presented in Tables 3-5 from Casas-Peña et al. (in proc.).

\subsection{Whole-rock geochemical analysis}

All samples were used for whole-rock geochemical analysis. A detailed description of the geochemical processing and analytical methods used is provided in the supplementary data (Casas-Peña et al., 2021). Raw and processed data are listed in Tables 10 and 11 (Casas-Peña et al., 2021). The distributions of the elements in random samples were described using the arithmetic mean and confidence limits (95\% and 99\%, respectively) supplied by the Student's t-test (Borradaile, 2003; Tables 12 and 13; Casas-Peña et al., 2021). Major elements were analyzed by inductively coupled plasma optical emission spectrometry (ICP-OES) and trace elements by inductively coupled plasma mass 


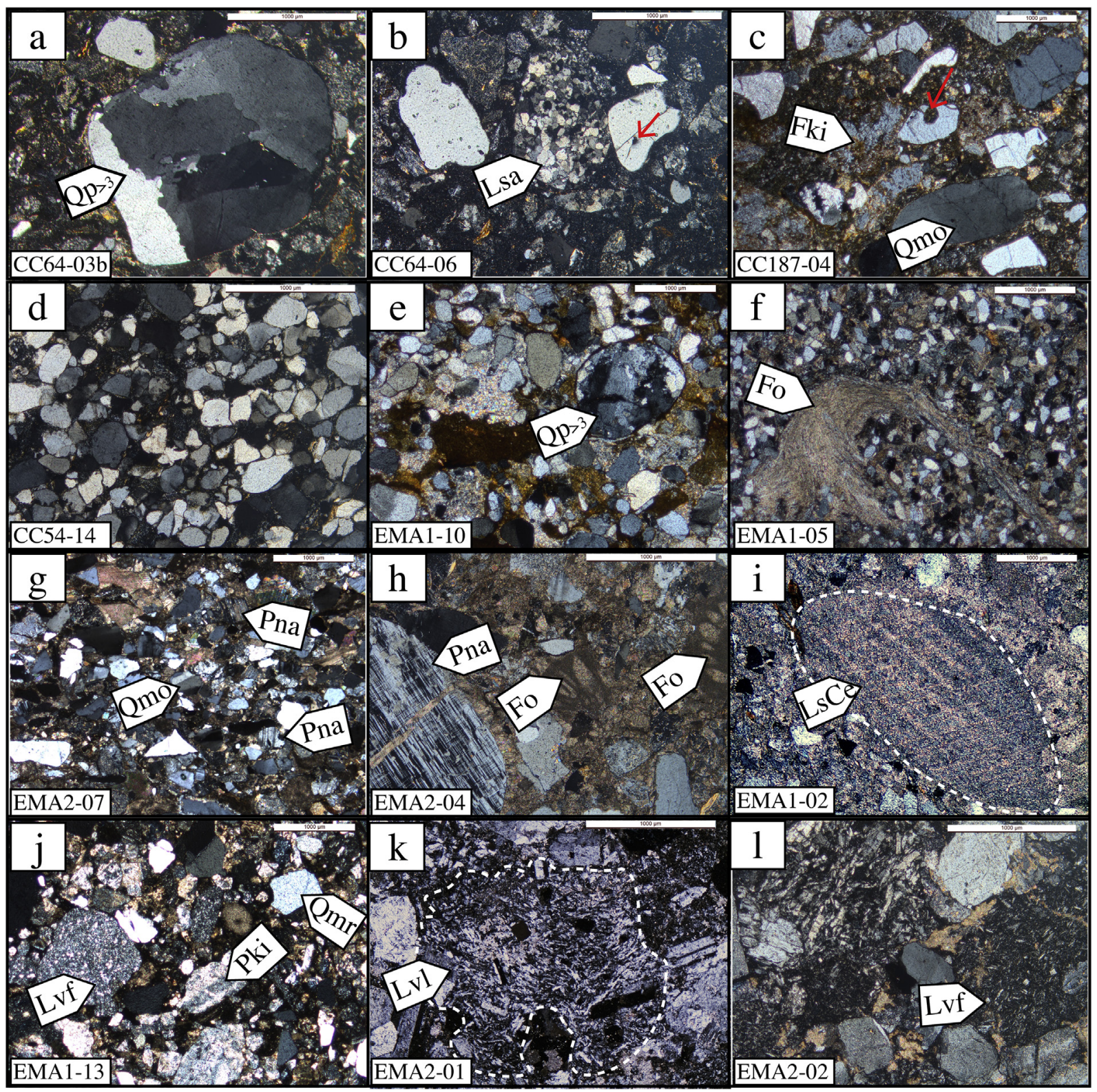

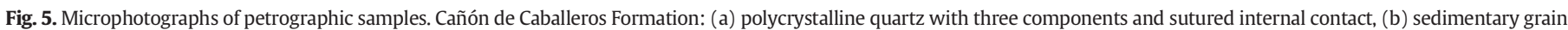

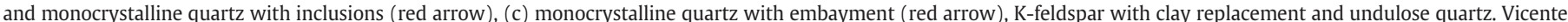

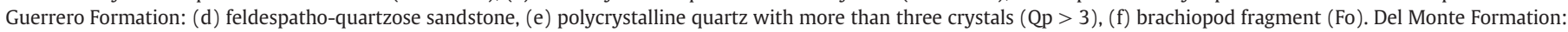

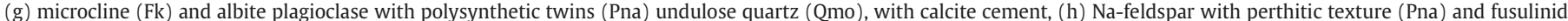

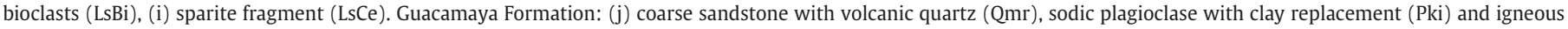
fragments with felsitic texture (Lvf), (k) igneous grain with lathwork texture, (l) igneous grains with felsitic texture in a coarse-grained sandstone.

spectrometry (ICP-MS) at the ACME laboratories, Vancouver, Canada. Geochemical data were plotted separately for each section into the following diagrams: $\mathrm{K}_{2} \mathrm{O} / \mathrm{Na}_{2} \mathrm{O}$ (Jenchen, 2018a, 2018b), $\mathrm{SiO}_{2} / \mathrm{Al}_{2} \mathrm{O}_{3}$ (Jenchen and Rosenfeld, 2007; Jenchen, 2018a, 2018b), Ti/Nb-SiO $/$ $\mathrm{K}_{2} \mathrm{O}$ (Jenchen, 2018a, 2018b), $\mathrm{Cr}-\mathrm{Th} / \mathrm{Sc}$ (Jenchen, 2018a), $\mathrm{Al}_{2} \mathrm{O}_{3}-$ $\mathrm{CaO}^{*}+\mathrm{Na}_{2} \mathrm{O}-\mathrm{K}_{2} \mathrm{O}$ (Nesbitt and Young, 1982; Fedo et al., 1995), Th/ $\mathrm{Sc}-\mathrm{Zr} / \mathrm{Sc}$ (McLennan et al., 1993), $\mathrm{SiO}_{2} / \mathrm{Al}_{2} \mathrm{O}_{3}-\mathrm{K}_{2} \mathrm{O} / \mathrm{Na}_{2} \mathrm{O}$ (Jenchen, 2018a, 2018b), Th-Co-Zr/10, and La-Th-Sc (Bhatia and Crook, 1986) as well as Rock/Chondrite vs. REE normalized (Taylor and McLennan, 1985). In addition, a composite stratigraphic column with selected geochemical parameters of the Tamatán Group is shown in Fig. 12. Displaying a summary of compositional changes during the development of the Tamatán successions.

\section{4. $U-P b$ geochronology}

Geochronological analyses were conducted for four coarsegrained sandstone samples that were considered representative of each formation of the Tamatán Group. In particular, samples CC64-04 and CC54-14 were obtained from the lower members of the Cañón de Caballeros and Vicente Guerrero formations in section 5 (Caballeros Canyon). Samples CP207-07 and CP197-03 were obtained at the middle portion of the Del Monte and Guacamaya formations in sections 2 and 1 (Peregrina Canyon; see Fig. 3). All samples were routinely analyzed for $\mathrm{U}-\mathrm{Pb}$ detrital zircon ages with a total of 441 spots (109 from the Cañón de Caballeros Formation, 113 from the Vicente Guerrero Formation, 110 from 

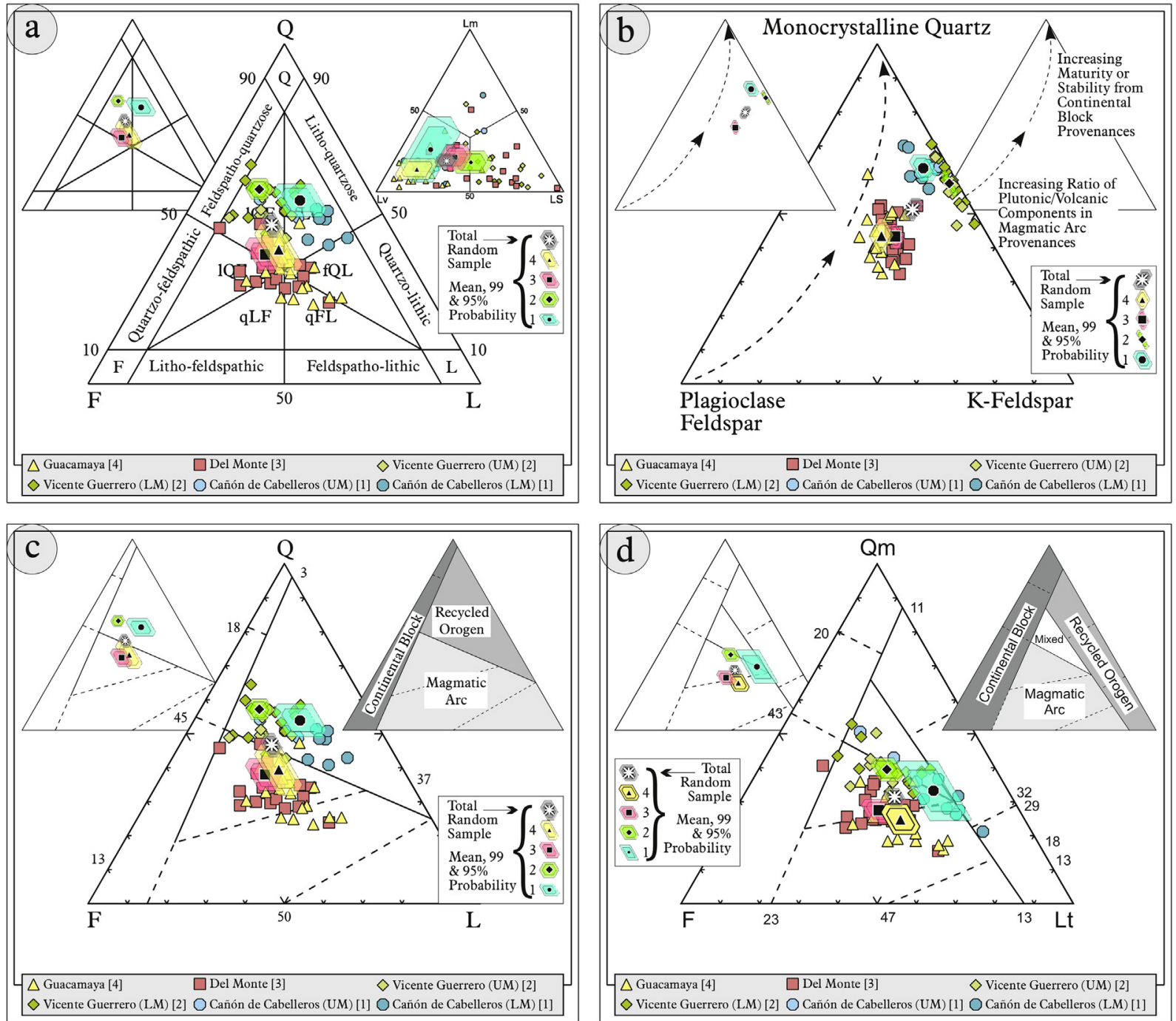

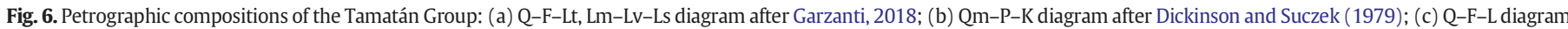
after Dickinson et al. (1983); (d) Qm-F-Lt diagram after Dickinson (1985). For additional diagrams and raw data please consult Casas-Peña et al., 2021).
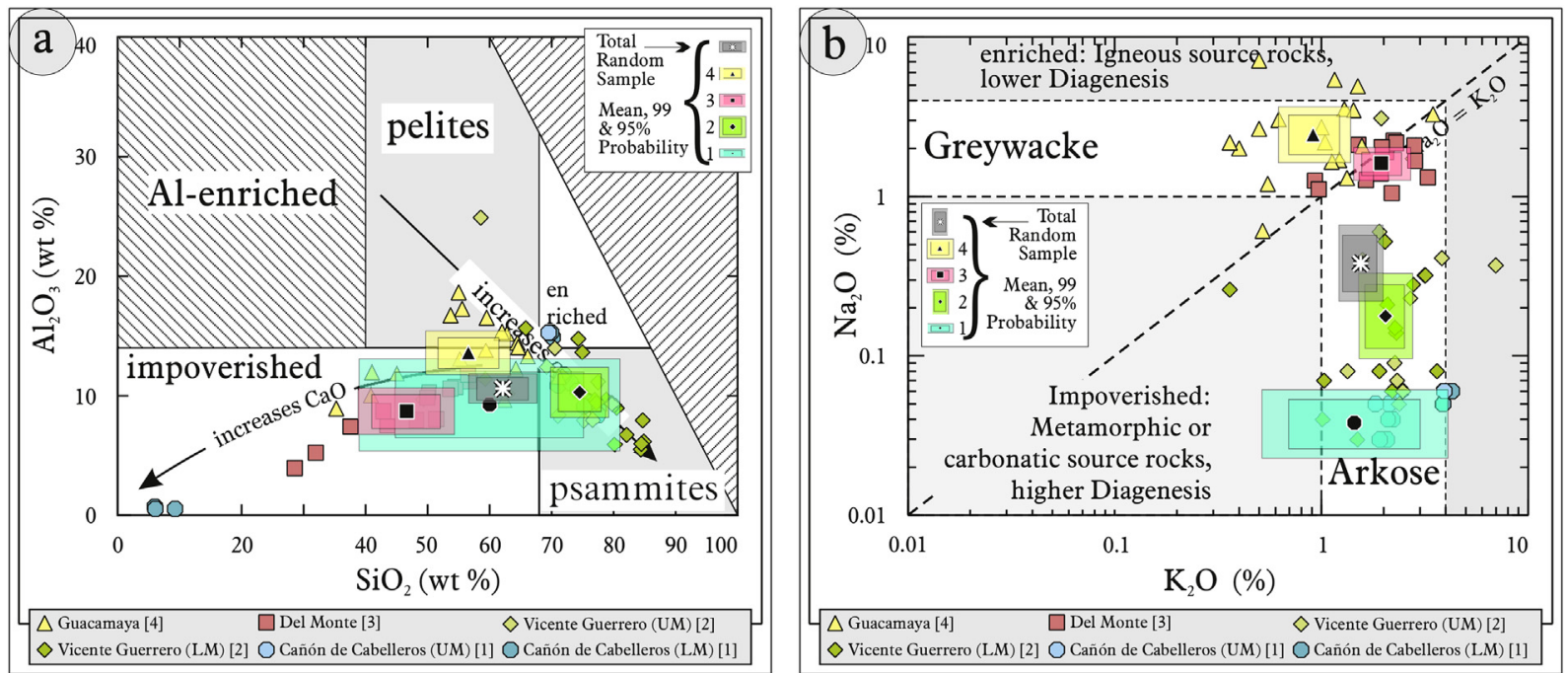

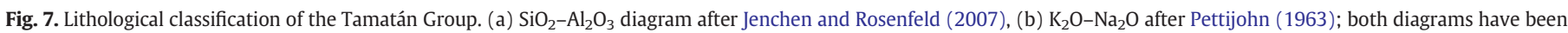
modified by Jenchen (2018a). 
the Del Monte Formation, and 109 from the Guacamaya Formation, as shown in Tables 14-21 (Casas-Peña et al., 2021).

All zircons from the samples were processed following standard procedures at the Geology Department at the "Centro de Investigación Científica y de Educación Superior de Ensenada Baja California (CICESE)" using a Wilfley table, a Frantz isodynamic separator, and sodium polytungstate heavy liquid and final selction by handpicking. Zircon grains were placed on epoxy mounts and polished. We performed laser ablation multicollector inductively coupled plasma mass spectrometry data acquisition at the Central Analytical Facilities, Stellenbosch University in South Africa. A Thermo ${ }^{\circledR}$ Element2 ${ }^{\circledR}$ mass spectrometer coupled to a NewWave UP213 laser ablation system $(\lambda=213 \mathrm{~nm}, \mathrm{f}=10 \mathrm{~Hz})$ was used, following the analytical and data processing described in Gerdes and Zeh $(2006,2009)$ and Frei and Gerdes (2009). U-Pb geochronological analysis was conducted on randomly selected grains; however, cores were preferred in order to avoid the influence of possible metamorphic overgrowths. The GJ-1 reference zircon was used as the primary standard (ID TIMS $608.5 \pm 0.4$ Ma; Jackson et al., 2004). U-Pb data were obtained using a spot diameter of $30 \mu \mathrm{m}$. For quality control, the Plešovice (Sláma et al., 2008) and M127 (Nasdala et al., 2016) zircon reference materials were analyzed. The following masses were measured: ${ }^{202} \mathrm{Hg},{ }^{204}(\mathrm{~Pb}+\mathrm{Hg}),{ }^{206} \mathrm{~Pb},{ }^{207} \mathrm{~Pb},{ }^{208} \mathrm{~Pb},{ }^{232} \mathrm{Th},{ }^{235} \mathrm{U}$, and ${ }^{238} \mathrm{U}$. The ${ }^{202} \mathrm{Hg}$ mass was measured to monitor ${ }^{204} \mathrm{Hg}$ interference on ${ }^{204} \mathrm{~Pb}$ (using a ${ }^{202} \mathrm{Hg} /{ }^{204} \mathrm{Hg}$ ratio of 4.36).

Age-probability plots (Ludwig, 2012) were constructed using the "best apparent age," that is, the ${ }^{206} \mathrm{~Pb}^{/ 238} \mathrm{U}$ age for zircon grains younger than $900 \mathrm{Ma}$, and the ${ }^{207} \mathrm{~Pb} /{ }^{206} \mathrm{~Pb}$ age for zircon grains older than $900 \mathrm{Ma}$. The rationale for this division at $900 \mathrm{Ma}$ results from the increasing uncertainty of ${ }^{206} \mathrm{~Pb} /{ }^{238} \mathrm{U}$ ages and decreasing uncertainty of ${ }^{207} \mathrm{~Pb} /{ }^{206} \mathrm{~Pb}$ ages as a function of age. Ages of $>10 \%$ discordance were discarded. All ages were plotted on Wetherill Concordia and relative age-probability diagrams using IsoplotR (Vermeesch, 2018). Probability peak ages and $2 \sigma$ errors were calculated using radial bivariate scatter plots in the IsoplotR software.

\section{Results}

\subsection{Field observations}

The outcrops of the Tamatán Group exhibit a scattered outcrop pattern; they are discontinuous, commonly exhibit local faults, and are separated by unconformities from the underlying Precambrian rocks and the overlying Mesozoic redbeds.

\subsubsection{Cañón de Caballeros Formation (Silurian: Wenlock-Ludlow)}

The Silurian Cañón de Caballeros Formation forms the oldest strata of the Tamatán Group. It is exposed in both canyons (Caballeros and Peregrina) and represents the following three incomplete subunits of shallow-marine sediments containing a Silurian fauna (Stewart et al., 1999).

1. The Lower Member (up to $25 \mathrm{~m}$; middle Wenlock after Boucot et al., 1997; Fig. 4) is best preserved in the Caballeros Canyon (section S4; Fig. 4). It consists of alternating conglomerates and coarse-grained sandstones, normally graded from coarse- to fine-grained sandstones and includes more silty portions with shale at the upper parts. Massive sandstones with cross-bedding dominate the upper part (Fig. 3a; Casas-Peña et al., 2021). The Lower Member is in tectonic contact with gneisses of the Novillo metamorphic complex (Fig. 3a; Casas-Peña et al., 2021). In the Peregrina Canyon, the Lower Member is unconformably overlain by the younger Santa Ana member and/or the Vicente Guerrero Formation (Fig. 4). In the Peregrina Canyon (Section S3; Fig. 4), consist of thickness coarsegrained sandstones with concave lamination and very thin shale beds ( $~ 8 \mathrm{~m}$ ). This member is probably unconformably overlain by the younger Santa Ana member and the Vicente Guerrero Formation.
2. The Santa Ana member consists of $9 \mathrm{~m}$ of light gray, highly fractured bioclastic grainstone with abundant clay and iron-oxide filled stylolites intercalated with thin shale beds. The unit features a Wenlock to Ludlowian fauna (Boucot et al., 1997; Stewart et al., 1999; see Fig. 3 in Casas-Peña et al., 2021).

3. The Upper Member (Ludlow to Pridoli; Boucot et al., 1997) (Fig. 4) comprises fine-grained sedimentary rocks, including shales, siltstone, and fine-grained sandstone, with an overall thickness of approximately $13 \mathrm{~m}$. However, Stewart et al. (1999) determined a thickness of $100 \mathrm{~m}$ (Fig. 3d; Casas-Peña et al., 2021).

The complete Cañón de Caballeros Formation is characterized by upward-fining sequences (Fig. 3, Casas-Peña et al., 2021), local lenticular bedding, and cross-stratification. Considered together with the reported marine organisms, an interpretation of shallow-marine deposits is postulated.

\subsubsection{Vicente Guerrero Formation (Carboniferous: Early Mississippian)}

The Vicente Guerrero Formation crop out in the Peregrina Canyon, either in tectonic contact with the Novillo Complex or uncomfortably overlying the Cañón de Caballeros Formation. In the Caballeros Canyon it is exposed ca. $400 \mathrm{~m}$ west of the Aserradero Ranch. There is overlain by an angular unconformity by the younger Del Monte Formation. (Fig. 4, Stewart et al., 1999).

This formation is divided into two members:

1. The Lower Member is composed of medium- to fine-grained sandstones and occasionally conglomerate $(\sim 11 \mathrm{~m}$ thick; Fig. 3 and Fig. 4). In the Caballeros Canyon, channelized sandstones reach their greatest thickness. In the Peregrina Canyon, thin beds $(\sim 10-30 \mathrm{~cm})$ of conglomerate with fossiliferous boulders and coarse-grained sandstones are intercalated with medium- to finegrained sandstones (Fig. 3e; Casas-Peña et al., 2021). A shallow water fauna has been described by Stewart et al. (1999) and SourTovar et al. (2005).

2. The Upper Member (Fig. 4) is exposed exclusively to the Peregrina Canyon (20 m), where it is composed of silty fine-grained sandstone interbedded with strongly deformed siltstone and shale. Occasional local slumps as well as large sandy channels of massive, coarse sandstone with basal conglomerate, containing elongated and rounded clasts up to $10 \mathrm{~mm}$ (see Fig. 3, Casas-Peña et al., 2021), occur with brachiopod-rich horizons arranged randomly.

\subsubsection{Del Monte Formation (Carboniferous: Middle Pennsylvanian)}

The Del Monte Formation (200 m; Carrillo-Bravo, 1961; Gursky, 1994) outcrops are widespread in both canyons (Fig. 4). It discordantly overlies the Vicente Guerrero Formation in the Caballeros Canyon and is unconformably overlain by the Guacamaya Formation in both canyons.

In some instances, wavy and irregular bedding exist. The Del Monte Formation includes several calcarenite facies, such as calcareous debris flows with mud rip-up clasts, calcareous sandstones, and massive marine calcarenite with local fining upward sequences (Fig. 4i; CasasPeña et al., 2021), and calcarenites alternating with dark-gray laminar calcareous siltstones. Calcareous strata contain fusulinids, corals, and ammonite molds of Moscovian age (Stewart et al., 1999). The depositional environment marks a change from shallow marine to marine slope or canyon fill deposits.

Parts of flysch facies such as graded bedding, mud rip-up clasts, horizontal and ripple laminations, and segmented trails of organisms are present in thin- to medium-bedded sandstones (see Fig. 4, Casas-Peña et al., 2021). Calcareous strata contain bioclastic fusulinids, corals, and goniatide molds (Fig. 4, Casas-Peña et al., 2021) of Moscovian age (Stewart et al., 1999). We also identified the former basal Naranjal Conglomerate (Carrillo-Bravo, 1961) which forms now the basal part of the Del Monte Formation. It consists of abundant angular to sub-rounded fragments ( $\sim 3$ to $20 \mathrm{~cm}$ ) of granitic igneous, metamorphic, and sedimentary (sandstone) clasts (see Fig. 4, Casas-Peña et al., 2021). 


\subsubsection{Guacamaya Formation (Permian: Cisuralian)}

The Early Permian Guacamaya Formation discordantly overlies the Del Monte Formation (Gursky and Michalzik, 1989; Gursky, 1994). In the Caballeros Canyon, it is overthrusted by the Granjeno Complex. In the Peregrina Canyon this formation is discordantly covered by the Jurassic La Boca Formation. The Guacamaya Formation consists of distal turbiditic deposits. In the Caballeros Canyon, it exhibits massive conglomerates, coarse sandstones, and poorly stratified sandstones. In the Peregrina Canyon, outcrops include rhythmic intercalations of shales and sandstones and classical Bouma sequences (Bouma, 1962).

The conglomerate beds can comprise quartz and feldspar fragments, whitish limestone clasts, and dark igneous fragments bound in calcareous cement ( 1 to $5 \mathrm{~cm}$; see Fig. 5; Casas-Peña et al., 2021). Bedding strata are quite sharp but sometimes rippled. Common internal bedding structures are horizontal, cross-current ripple, minor convolute laminations, and graded bedding. The Bouma sequence is also common (Fig. 5, Casas-Peña et al., 2021).

\subsection{Sandstone petrography}

Sandstones from the Cañón de Caballeros and Vicente Guerrero formations are dominated by non-carbonate extrabasinal grains (NCE; Zuffa, 1985; see table 3 to 5, Casas-Peña et al., 2021). Both formations exhibited a high to moderate quartz detrital mode in the Lower member and low quartz in the Upper member (e.g., Fig. 5a-f). Grains are rounded, sub-rounded, and sub-angular, exhibiting low compaction and dominance of point contact. Most grains are associated with the illite matrix. The samples can be classified as feldspatho-lithic-quartzose and lithofeldspatho-quartzose, respectively (after Garzanti, 2016; Fig. 6a).

The mineralogical composition of the Cañón de Caballeros and Vicente Guerrero formations consists of monocrystalline quartz. Quartz with straight extinction is more abundant than quartz with undulose extinction, and the mean values of $\mathrm{Qmr} / \mathrm{Qmo}$ ratio are $x=0.42$ and 0.38 , respectively. Monocrystalline quartz grains are euhedral to subhedral and sometimes elongated (Fig. 5a-e); some contain embayments, inclusions, fractures, vacuoles, and some are filled by clay minerals (e.g., Fig. 5b-c). Regarding quartz, the polycrystalline quartz grains with $2-3$ crystals are more abundant ( $\mathrm{QP}_{\mathrm{NCE}} x=15 \%$ and $13 \%$ ) than those with $>3$ crystals $\left(\mathrm{Qp}_{2-3} / \mathrm{Qp}_{>3} x=1.2\right.$ and 5.9$)$ and sutured contacts between crystals are typical (Fig. 5a). Feldspars are dominated by sanidine and microcline, which are sometimes partly replaced by illite (e.g., Fig. 5c), albitic plagioclase is scarce with a mean P/F ratio of 0.2 and 0.05 , respectively. Both the Cañón de Caballeros and Vicente Guerrero sandstones show abundant monocrystalline quartz ( $x=63 \%$ and $59 \%$, respectively) and K-feldspar content ( $x=29 \%$ and 39\%, respectively) but low plagioclase content ( $x=7 \%$ and $2 \%$ ), as shown in Fig. $6 \mathrm{~b}$.

Among the lithic fragments (Fig. 6a), igneous fragments are more dominant ( $x=48 \%$ and 36\%, respectively). They include microcrystalline felsitic clasts, plutonic rock grains with K-feldspar, biotite, and sedimentary clasts $(x=32 \%$ and $48 \%$ ) such as clastic silty lithics, extrabasinal carbonaceous grains $(C E)$ (e.g., sparite fragments and microfossils; (Fig. 5f), and bioclastic intrabasinal fragments (CI). The less frequent metamorphic lithoclasts $(x=19 \%$ and 16\%) include largely elongated grains, mostly from low-grade metapelitic and metapsammitic fragments (e.g., Table 7, Casas-Peña et al., 2021). Other components include chert, biotite, muscovite, chlorite micas, and Fe-minerals (hematite and pyrite). From the total of the components they comprise only 6\% in Cañón de Caballeros Formation and 7\% in Vicente Guerrero Formation. Heavy minerals such as zircon, apatite, and titanite correspond to $1 \%$ and $3 \%$, respectively. In the Cañón de Caballeros and Vicente Guerrero formations, rare recrystallized carbonate grains, as well as amphibole grains are documented (sample CP187-04; Table 6 and Table 7, Casas-Peña et al., 2021).

The content mean values of the samples of the Cañón de Caballeros and Vicente Guerrero formations is similar: $52 \%$ and $56 \%$ total quartz, $21 \%$ and $29 \%$ total feldspar, and $27 \%$ and $14 \%$ total lithics, with values of $41 \%$ and $48 \%$ total monocrystalline quartz, $24 \%$ and $34 \%$ total feldspar, and $35 \%$ and $18 \%$ total lithics, respectively. These formations are grouped in the recycled orogen field, with a mixed trend toward the continental block provenance field (Fig. 6c-d).

Sandstones from the Del Monte and Guacamaya formations comprise grains with low to moderate compaction, as shown by the dominance of point and plane contact (Table 8, Casas-Peña et al., 2021). Their grains are sub-angular to sub-rounded and occasionally fractured. The Del Monte and Guacamaya formations samples are classified as feldspatho-quartzo-lithic and litho-quartzo-feldspathic (Fig. 6a). The Del Monte and Guacamaya formations have lower monocrystalline quartz detrital modes ( $x=43 \%$ and $44 \%)$ but higher K-feldspar $(x=33 \%$ and $29 \%$ ) and plagioclase content ( $x=24 \%$ and 27\%), respectively, than Cañón de Caballeros and Vicente Guerrero formations (Fig. 3g-1 and Fig. 4b; Tables 6-9; Casas-Peña et al., 2021).

Most components from the Del Monte Formation samples are embedded in calcite cement with a patch of dolomite rhombs, with the exception of the Guacamaya Formation, which presents both clay and calcite cements. Quartz is mostly monocrystalline $\left(\mathrm{Qm}_{\mathrm{NCE}} x=28 \%\right.$ and $24 \%$ ), predominantly with straight extinction ( $\mathrm{Qmr} / \mathrm{Qmo} x=0.6$ and 0.3); however, monocrystalline quartz with inclusions and syntaxial overgrowths is also common. Polycrystalline quartz mostly includes elongated grains composed of more than three crystals, which tend to be joined by point and sutured crystal contacts and, more rarely, with calcite and/or clay replacement (Fig. $5 \mathrm{j}$ ). In the samples from the Del Monte Formation the K-feldspar/plagioclase relation is lower than $1(\mathrm{P} / \mathrm{F} x=0.4$ and 0.5$)$. K-feldspar mostly shows Carlsbad twinning or a microcline grid (e.g., Fig. $5 g$ ). Plagioclase exhibits polysynthetic twinning, zonation, as well as sericitic and calcite replacement (Fig. 5g-h).

Among the lithic fragments from the Del Monte and Guacamaya Formations, sedimentary ( $x=52 \%$ and $27 \%$, respectively) and igneous ( $x=$ $33 \%$ and $61 \%$, respectively) are more abundant than metamorphic lithics ( $x=15 \%$ and $12 \%$, respectively). Chert is also present ( $x=4 \%$ and $7 \%$, respectively; (Fig. 6a). The sandstones of Del Monte Formation display igneous grains with felsitic textures showing phenocrysts of quartz, feldspar, and mica (e.g., (Fig. 5j-1). In the Guacamaya Formation, volcanic microlitic and lathwork textures are common (Fig. 5k). Sedimentary fragments are also frequently observed (see Table 5 and Table 6, CasasPeña et al., 2021), consisting primarily of sparite (e.g., Fig. 5i), micrite, and arenite fragments. In the Del Monte Formation, microfossils are abundant, including biserial foraminifera, conchoids, and miliolids (e.g., Fig. 5h) as well as ooids and other bioclastic intrabasinal grains. Metamorphic grains ( $x=16 \%$ and 10\%) mostly have a metasedimentary texture characterized by lithic grains with quartz and mica. Mica (biotite, muscovite), heavy minerals, and opaque minerals (e.g., pyrite) also occur.

The Del Monte and Guacamaya Formations exhibit mean values of $39 \%$ and $36 \%$ total quartz, $40 \%$ and $35 \%$ total feldspar, and $21 \%$ and $28 \%$ total lithics, with values of $32 \%$ and $30 \%$ total monocrystalline quartz, $41 \%$ and $37 \%$ total feldspar, and $27 \%$ and $33 \%$ total lithics. These formations can be grouped in the magmatic provenance field (Fig. 6c-d).

\subsection{Geochemistry}

\subsubsection{Mineralogical and lithological classification}

The highest $\mathrm{SiO}_{2}$ concentrations can be observed in samples of the Cañón de Caballeros and Vicente Guerrero formations, ranging from $69 \%$ to $78 \%(x=73 \%)$ and $49 \%$ to $85 \%(x=74 \%)$ with moderate $\mathrm{Al}_{2} \mathrm{O}_{3}$ values of $8 \%$ to $15 \%(x=11 \%)$ and $5 \%$ to $14 \%(x=10 \%)$ and $\mathrm{K}_{2} \mathrm{O}$ values of $2 \%$ to $4 \%(x=3)$ and $0.36 \%$ to $4.0 \%(x=2 \%)$, respectively; $\mathrm{Na}_{2} \mathrm{O}, \mathrm{CaO}$, $\mathrm{MgO}, \mathrm{MnO}, \mathrm{P}_{2} \mathrm{O}_{5}$, and $\mathrm{TiO}_{2}$ values are low $(x=2 \%)$. Low quantities of $\mathrm{Na}_{2} \mathrm{O}, \mathrm{CaO}$, and $\mathrm{MgO}$ were found in the upper members of both formations (Casas-Peña et al., 2021).

In contrast, the Del Monte and Guacamaya Formations exhibit lower $\mathrm{SiO}_{2}$ contents of $28 \%$ to $57 \%(x=46 \%), 35 \%$ to $71 \%(x=56 \%)$, and 
moderate $\mathrm{Al}_{2} \mathrm{O}_{3}$ contents from $4 \%$ to $11 \%(x=8 \%)$ and $9 \%$ to $18 \%$ $(x=13 \%)$ as well as $\mathrm{K}_{2} \mathrm{O}$ contents ranging from $1 \%$ to $3 \%(x=2 \%)$ and $0.5 \%$ to $1.5 \%(x=1 \%)$, while their $\mathrm{Na}_{2} \mathrm{O}$ contents range from $1 \%$ to $2 \%(x=2 \%)$ and $1 \%$ to $7 \%(x=3 \%)$, respectively. Due to the high carbonate content, the $\mathrm{CaO}$ concentration ranges from $9 \%$ to $35 \%(x=19 \%)$ and from $0.2 \%$ to $19 \%(x=6 \%)$.

Most samples from the Cañón de Caballeros and Vicente Guerrero formations are classified as psammites, with the exception of several Vicente Guerrero samples, which are distinguished by their $\mathrm{CaO}$ enrichment. All Del Monte samples were classified as $\mathrm{CaO}$-enriched sediments. The Guacamaya Formation is classified within $\mathrm{CaO}$-enriched pelites (Fig. 21a; Table 13; Casas-Peña et al., 2021). Arkoses exhibit a negative correlation between $\mathrm{Al}_{2} \mathrm{O}_{3}$ and $\mathrm{SiO}_{2}$, whereas greywackes exhibit negative correlations of both $\mathrm{SiO}_{2}$ and $\mathrm{Al}_{2} \mathrm{O}_{3}$ with $\mathrm{CaO}$ (Fig. 7b).

\subsubsection{Weathering, recycling, and source area}

In the Tamatán Group, the Cañón de Caballeros and Vicente Guerrero formations show a high to moderate interval of alteration. Values of the "Chemical Index of Alteration" (CIA; Nesbitt \& Young,1982) range from 61 to 83 (mean $x=75$ ) and 56 to $84(x=76)$, whereas the lowest values were found in the Del Monte and Guacamaya Formations, where CIA values range from 40 to 68 (mean $x=56$ ) and 51 to 78 (mean $x=61$ ), respectively. The mean values are also included in the Plagioclase Index Alteration (PIA; Fedo et al., 1995) and chemical index of weathering (CIW; Harnois, 1988) of the Tamatán Group range from 60 to 92 (table 10-13, Casas-Peña et al., 2021). The CIA ternary plot (Nesbitt and Young, 1982; Fedo et al., 1995) can reflect the provenance of the material. For the Cañón de Caballeros and Vicente Guerrero formations, an initial felsitic source trend, whereas the Del Monte and Guacamaya Formations from a mafic-intermediate source trend. The Tamatán Group shows a similar geochemical trend to the average theoretical values of basalt, gabbro, granodiorite, rhyolite, and granitic compositions (e.g., Nesbitt and Young, 1982; Condie, 1993; (Fig. 8a).

The chemical composition of the Tamatán sedimentary rocks is also influenced by recycling. Zr enrichment is distinguished in the Cañón de Caballeros and Vicente Guerrero formations, with a high $\mathrm{Zr} / \mathrm{Sc}$ ratio mean value of $x=138$ (range from 38 to 245) and $x=48$ (range, 7-202), respectively. The lower values in the Del Monte and Guacamaya formations show $\mathrm{Zr} / \mathrm{Sc}$ ratios with mean values of $x=18$ (range from 10 to 26) and $x=5$ (ranging from 3 to 8 ; see Table 14, Casas-Peña et al., 2021). Conversely, because Th and Sc are incompatible and compatible, respectively, in igneous differentiation processes, the $\mathrm{Th} / \mathrm{Sc}$ ratio indicates the degree of igneous differentiation (McLennan et al., 1993). The Cañón de Caballeros and Vicente Guerrero formations have relatively high to moderate $\mathrm{Th} / \mathrm{Sc}$ ratios $x=2.7$ and $x=0.8$, respectively; these values typically denote felsitic compositions. The Del Monte and Guacamaya formations show moderate to low values $(x=0.7$ and $x=0.2$ ), indicating intermediate to basic sources (Fig. 33b; Table 14, Casas-Peña et al., 2021).

\subsubsection{Provenance and tectonic setting}

The Tamatán Group reveals a trend from acidic (Cañón de Caballeros and Vicente Guerrero formations), intermediate (Del Monte Formation) to basic sources (Guacamaya Formation; (Fig. 9a). The Cañón de Caballeros Formation exhibits low to moderate Ti/Nb ratios ranging from 3.6 to $423(x=128)$ and $\mathrm{SiO}_{2} / \mathrm{K}_{2} \mathrm{O}$ ratios ranging from 17 to $40(x=28)$, whereas the Vicente Guerrero and Del Monte formations show moderate values with ranges of 66 to $600(x=384)$ and 300 to $671(x=501)$, including the $\mathrm{SiO}_{2} / \mathrm{K}_{2} \mathrm{O}$ ratio between 18 and $223(x=47)$ and 16 to 34 $(x=24)$, respectively. The Guacamaya Formation exhibits the highest $\mathrm{Ti} / \mathrm{Nb}$ ratio, ranging from 706 to $3340(x=1373)$, and has a high $\mathrm{SiO}_{2} / \mathrm{K}_{2} \mathrm{O}$ ratio, averaging 70 (Fig. 9b).

The Cañón de Caballeros and Vicente Guerrero Formation are associated with a passive margin field (Fig. 9c-d); however, some Vicente Guerrero and Del Monte samples are related to continental arcs. Samples from the Del Monte and Guacamaya Formations exhibit a trend from the active continental margin toward the oceanic island arc field (Fig. 9c-d).

The sum of rare earth elements from Tamatán Group is on average $122 \mathrm{ppm}$, with a moderate enrichment in the light rare earth elements (LREE), an average $\mathrm{La}_{\mathrm{N}} / \mathrm{Sm}_{\mathrm{N}}$ ratio of ca. 3.0 for all units, and flat heavy rare earth element patterns, with average $\mathrm{Gd}_{N} / \mathrm{Yb}_{\mathrm{N}}$ ratios of 1.4 (Fig. 10a). The Eu anomaly is most extreme in the Cañón de Caballeros Formation $\left(\mathrm{Eu} / \mathrm{Eu}^{*}=0.4\right)$. The other units have $\mathrm{Eu} / \mathrm{Eu}^{*}$ values of 0.6.0.8 (Fig. 38; Table 15, Casas-Peña et al., 2021). Average chondritenormalized REE patterns are relatively similar to those of the Upper Continental Crust (UCC), Post Archean Australian Shale (PAAS), and North American Shale Composite (NASC; Gromet et al., 1984; Taylor and McLennan, 1985).

The average REE distribution of the Tamatán Group is relatively similar to that of UCC (Fig. 10). Among the Tamatán units, the REE pattern of the Cañón de Caballeros Formation is notably different. This can be explained through transport and recycling processes, since mature
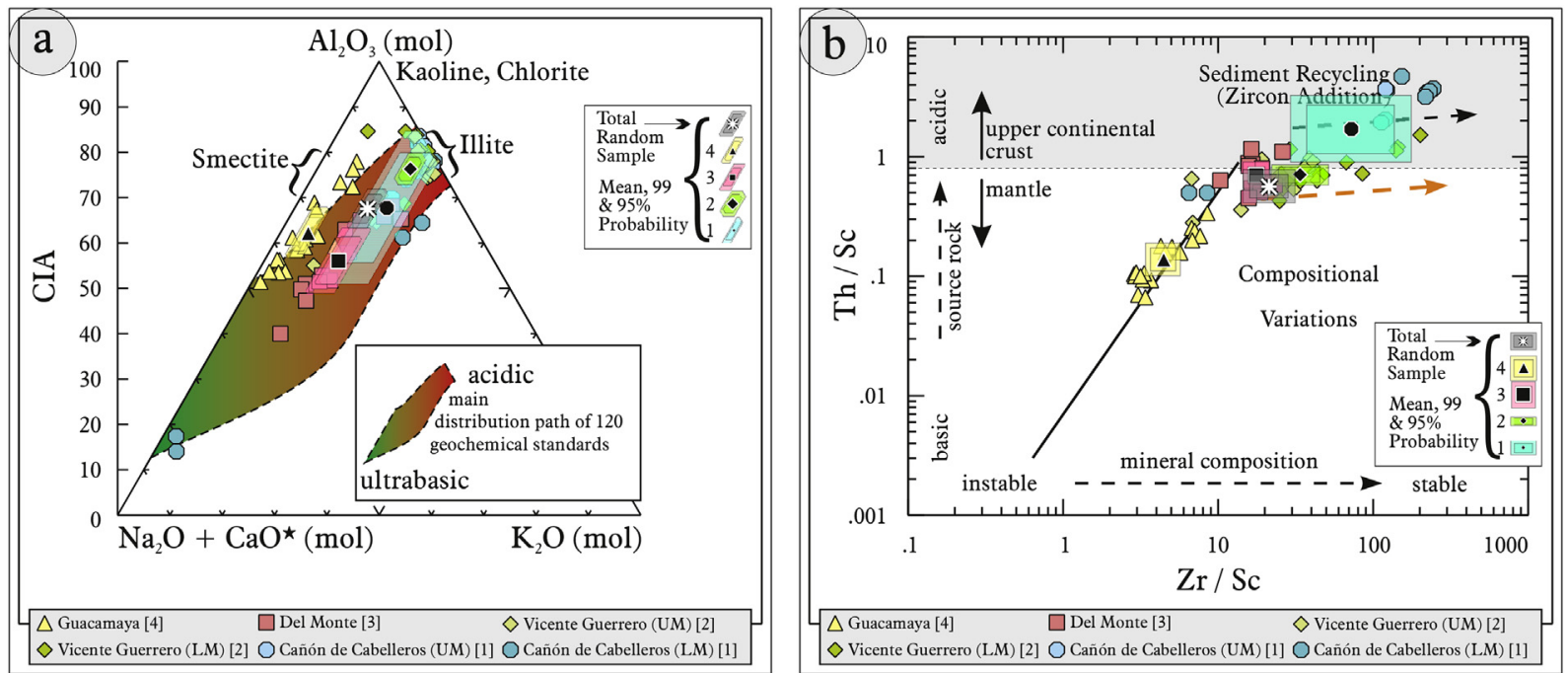

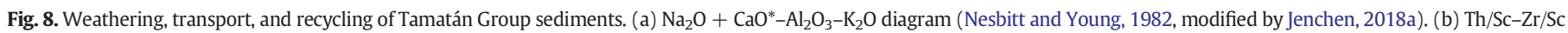
diagram (McLennan et al., 1993, modified by Bahlburg, 1998); Jenchen, 2001; Jenchen and Rosenfeld, 2007, and Jenchen, 2018a). 

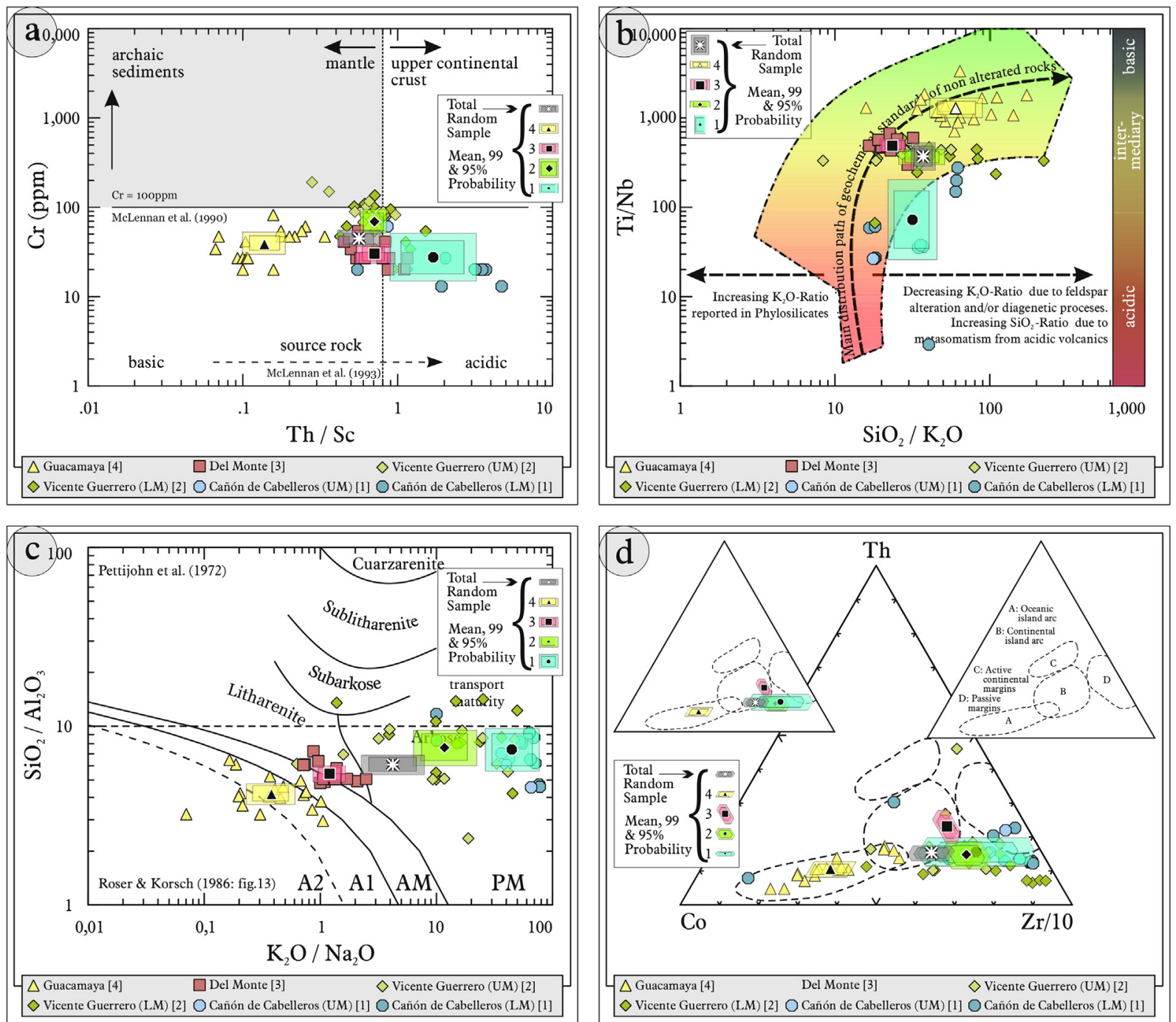

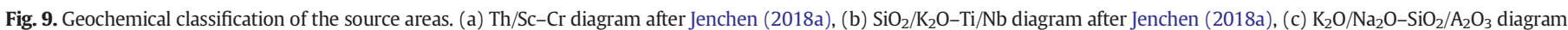
after Jenchen (2018a), (d) Th-Co-Zr/10 ternary plot after Bhatia and Crook (1986).
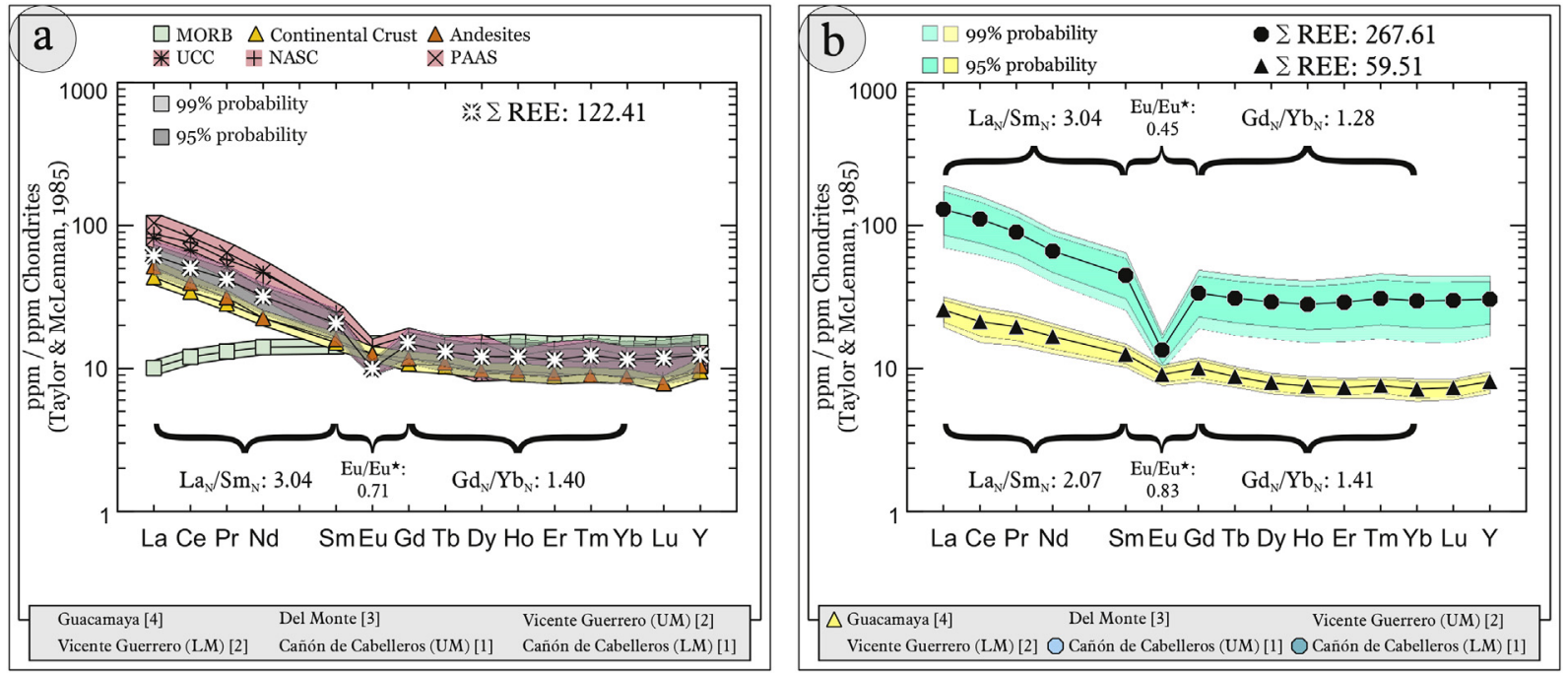

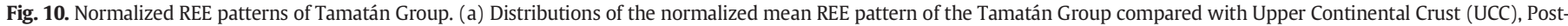

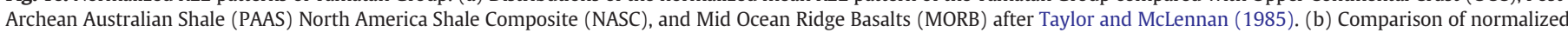
mean REE patterns from the Cañón de Caballeros and Guacamaya formations. 


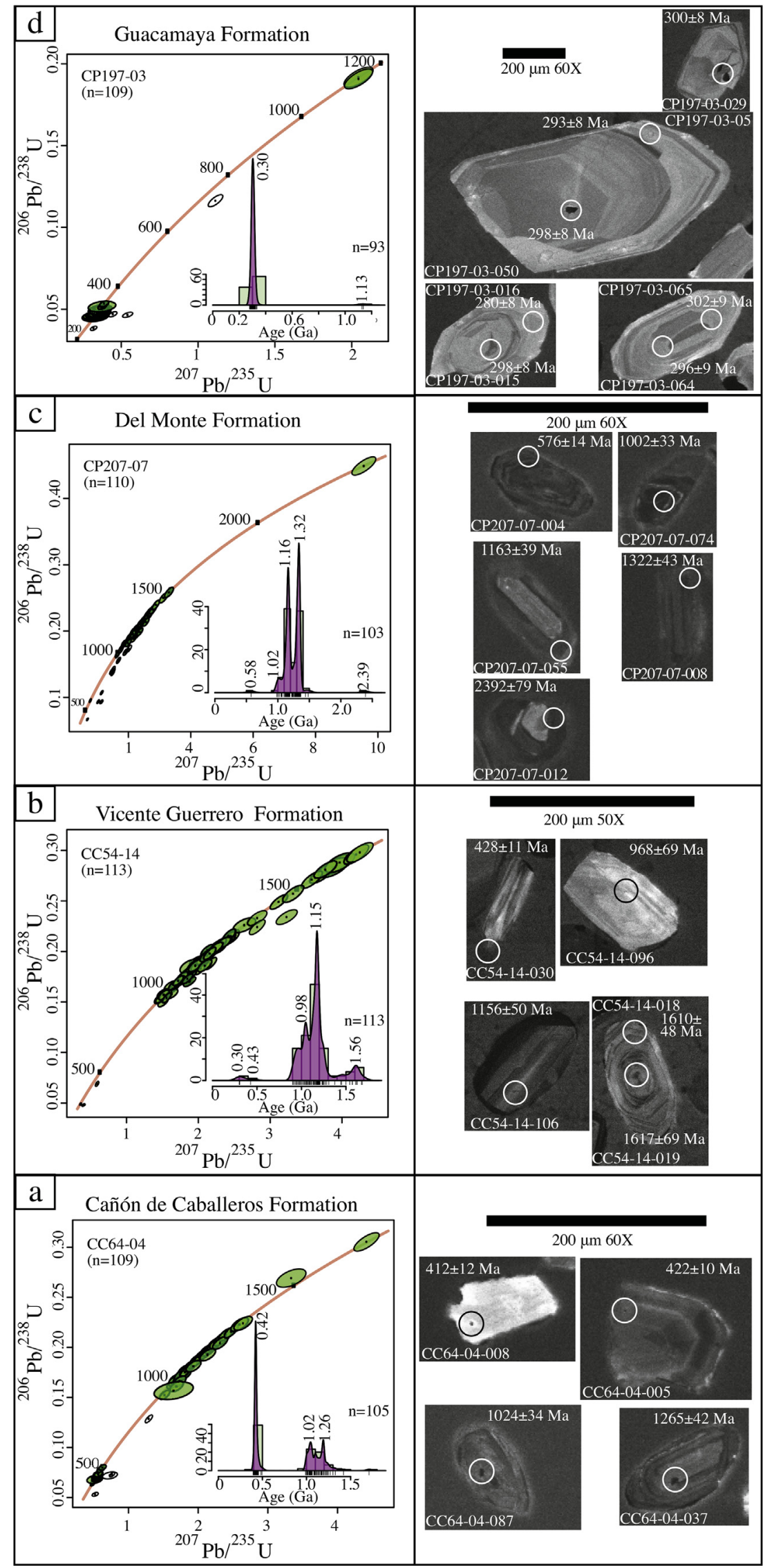

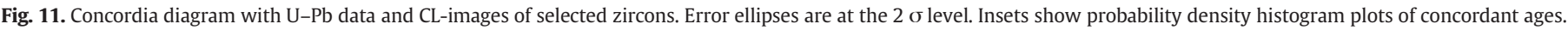

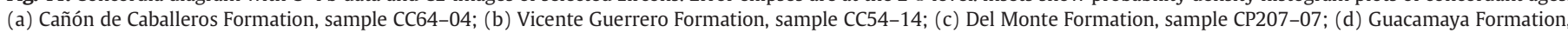
sample CP197-03. 
sandstones are typically enriched in LREE and tend to have sparse Naplagioclase with a strong Eu-anomaly (Fig. 10b). Significant differences in REE composition are probably due to the evolution of the passive margin toward magmatic arc settings, as reported in Bhatia (1985) and McLennan et al. (1993).

\section{4. $U-P b$ detrital-zircon ages of the Tamatán Group}

Zircon grains from the Cañón de Caballeros Formation exhibit a great variety of morphologies, including short, prismatic, pyramidal, and rounded. Similarly, cathodoluminescence (CL) images show low- and high-luminescence grains and growth zones with oscillatory and patchy zoning. A total of 109 zircon grains from CC64-04, of which 105 grains yielded $<20 \%$ discordant and $<10 \%$ inversely discordant data, were analyzed. The resulting age ranges from $1712 \pm 42 \mathrm{Ma}$ to $397 \pm 11 \mathrm{Ma}$. Almost half of the analyzed zircon grains (48\%) yielded Ordovician to Early Devonian ages with a peak age of $426 \pm 2 \mathrm{Ma}$ (Fig. 11a). U-Pb isotope data from most other zircon grains plot along the concordia between 1330 and $990 \mathrm{Ma}$ with probability peaks at $1260 \pm 14 \mathrm{Ma}$ (23\%) and $1029 \pm 5 \mathrm{Ma}$ (29\%). Two zircon grains show significantly older ages of $1.42 \mathrm{Ga}$ and $1.71 \mathrm{Ga}$ (Table 16 and Table 17, Casas-Peña et al., 2021).

Zircon grains from the Vicente Guerrero Formation (sample CC54-14) exhibit a variety of morphologies and sizes and are mostly rounded. These grains show very low luminescence in $\mathrm{CL}$ images with or without oscillatory zoning, but a smaller number of grains have highly luminescent growth zones. A total of 113 zircon grains were analyzed. Two out of three Paleozoic zircon grains, two yielded strongly discordant ages. All other zircon grains yielded Precambrian ages ranging from 1680 to $910 \mathrm{Ma}$ (Fig. 11b). Most grains were aged between 1310 and $970 \mathrm{Ma}$, with peaks at $1187 \pm 7 \mathrm{Ma}(47 \%)$ and $1054 \pm 6 \mathrm{Ma}$ (24\%; Fig. 10b). A group of nine concordant grains between 950 and 911 Ma yielded a weight mean age of $934 \pm 9$ Ma (not shown). A group of twelve zircon grains yielded ${ }^{207} \mathrm{~Pb} /{ }^{206} \mathrm{~Pb}$ ages between 1.69 and $1.44 \mathrm{Ga}$, with a peak age of $1563 \pm 13 \mathrm{Ma}$ (Fig. 11b).

Most zircon grains from the Del Monte Formation (sample CP207-07) are rounded with dark, low luminescent CL images, whereas others show internal zoning that is mostly complex and not always oscillatory. A total of 110 zircon grains were analyzed; 103 were $<20 \%$ discordant and $<10 \%$ were inversely discordant. The youngest concordant grain is Ediacaran in age ( $586 \pm 15 \mathrm{Ma})$, while the oldest dates from the Early Paleoproterozoic ( $2394 \pm 36 \mathrm{Ma})$. U-Pb isotope data from all other concordant zircon grains plot along the concordia line between $1483 \mathrm{Ma}$ and $1003 \mathrm{Ma}$. From the analyzed grains, 48\% correspond to a peak at $1328 \pm 7 \mathrm{Ma}, 42 \%$ to a peak at $1166 \pm 8 \mathrm{Ma}$, and only eight grains define a weak peak at $1027 \pm 19$ Ma (Fig. 11c).

Zircon grains from the Guacamaya Formation (sample CP197-03) show short prismatic bi-pyramidal morphologies (i.e., not rounded) and are relatively large $(>100 \mu \mathrm{m})$. Most CL images display welldeveloped oscillatory zoning, occasionally with resorbed cores and late-stage growth zones. Of the 109 analyzed zircon grains, 16 were $>20 \%$ discordant and therefore excluded from further interpretation. Only two analyses yielded Mesoproterozoic ages; all other zircons yielded Late Pennsylvanian-Early Permian ages (335-279 Ma), forming a well-defined peak age at $303 \pm 1 \mathrm{Ma}(2 \sigma$; Fig. $11 \mathrm{~d})$.

\section{Discussion}

\subsection{Depositional environment}

According to the field observations, the Cañón de Caballeros Formation is essentially composed of conglomerates, limestones, sandstones, and shales. The marine fossils reported within (e.g., Boucot et al., 1997; Stewart et al., 1999) as well as the local sedimentological occurrence of lenticular bedding, cross stratification, and upward-fining grain succession (see Fig. 3; Casas-Peña et al., 2021), indicate that this formation was deposited in a shallow marine environment. As reported by Walker and Plint (1992), the occurrence of siliciclastic and carbonate strata as well sand-upward facies successions can accumulate during coastal progradation associated with a high-energy shallow marine system. Therefore, the predominance of conglomeratic to sandstone deposits and fossiliferous limestone suggests that the Cañon de Caballeros Formation was deposited in the high-energy marginal basin in the proximal part of the coast. According to Silurian fossils, the evidence for the existence of a marginal basin is also reported from Venezuela (Stewart et al., 1999).

Like the Cañón de Caballeros Formation, the Vicente Guerrero Formation is mainly composed of conglomerate, sandstone, and shale deposits. The Vicente Guerrero Formation is predominantly composed of normal grading, massive bank or bars, channel structures, slumps, cross-stratification, and sandy lens beds (see Fig. 3; Casas-Peña et al., 2021). Stewart et al. (1999) interpreted this formation as a sedimentary record of shallow marine deposits. However, the field observations, such as normal grading from coarse-grain (e.g., Lower member) to fine-grain strata (e.g., Upper member) as well as the chaotic arrangement from the Mississippian fauna indicate high energy related to a shallow marine environment in a marginal basin.

The sedimentary characteristicas, presented in the Pennsylvanian Del Monte Formation, such as basal polymictic conglomerate, debris flow deposits, the intercalation calcareous sandstone and shale as well as gradual lamination, indicate that the formation was deposited as a proximal turbidite near or within a pronoun submarine slope or canyon, which is also suggested by Stewart et al. (1999). However, cephalopod fragments, abundant fusulinids, and bioclastic rocks also suggest a shallow water carbonate platform. According to Pemberton and MacEachern (1992), the persistent segmented tracks indicating the presence of organisms also imply periods of deposition in a quiet outer shelf, slope, or in bathyal environment; therefore, the proximal environment is evident for the Del Monte Formation.

The Guacamaya Formation can be interpreted, based on sedimentological features (e.g., complete Bouma sequences, ripples, and crosslamination as well as rhythmic clastic beds) and according to Gursky and Michalzik (1989) and Stewart et al. (1999), as typical distal turbidite deposits, with coarse-grained massive beds as channel fills, observed in the Caballeros Canyon.

\subsection{Provenance of the Tamatán Group}

\subsubsection{Cañón de Caballeros Formation}

In the Cañón de Caballeros Formation, the abundance of quartz, feldspar, and igneous grains is notable (e.g., high $\mathrm{Qm} / \mathrm{Qp}(0.42)$ and low $\mathrm{P} / \mathrm{K}$ (0.2) ratios (Fig. 6a-b), which are commonly generated from felsitic igneous (e.g., sample CC64-06, Table 5, Casas-Peña et al., 2021) and subordinate psammitic metamorphic sources (Marsaglia, 1991). A felsitic magmatic source has been proposed as the dominant contributor, but psammitic sourced also plays an important role and is also associated with mature sands deposited at passive margins (e.g., McLennan et al., 1993; Jenchen, 2018a).

A feldspatho-litho-quartzose rock can be inferred from high $\mathrm{SiO}_{2}$ (69-78 wt\%), $\mathrm{Al}_{2} \mathrm{O}_{3}$ (8-15 wt\%), and $\mathrm{K}_{2} \mathrm{O}$ (2-4 wt\%), suggesting that quartz, feldspar, and mica have been present. The lowest $\mathrm{Na}_{2} \mathrm{O}$ (0.03-0.06 wt\%) and $\mathrm{CaO}(0.05-2.3 \mathrm{wt} \%)$ values can be attributed to the scarcity of Na-plagioclase and carbonate (Fig. 6a-b). Low carbonate contents are also reflected by the relatively high values of the CIA (75\%), which can indicate the plausible alteration of feldspar toward clay components (e.g., illite cement), likely causing a high grade of recycling (e.g., Nesbitt and Young, 1982; Fig. 8a; Fig. 12).

According to discrimination diagrams (Dickinson and Suczek, 1979; Dickinson, 1985), the Cañón de Caballeros sandstones are associated with recycled orogenic rocks, indicating that they were supplied from a mixing source area, as suggested by Garzanti (2016) (Fig. 6c-d). Applying the schemes proposed by Bhatia and Crook (1986), McLennan 


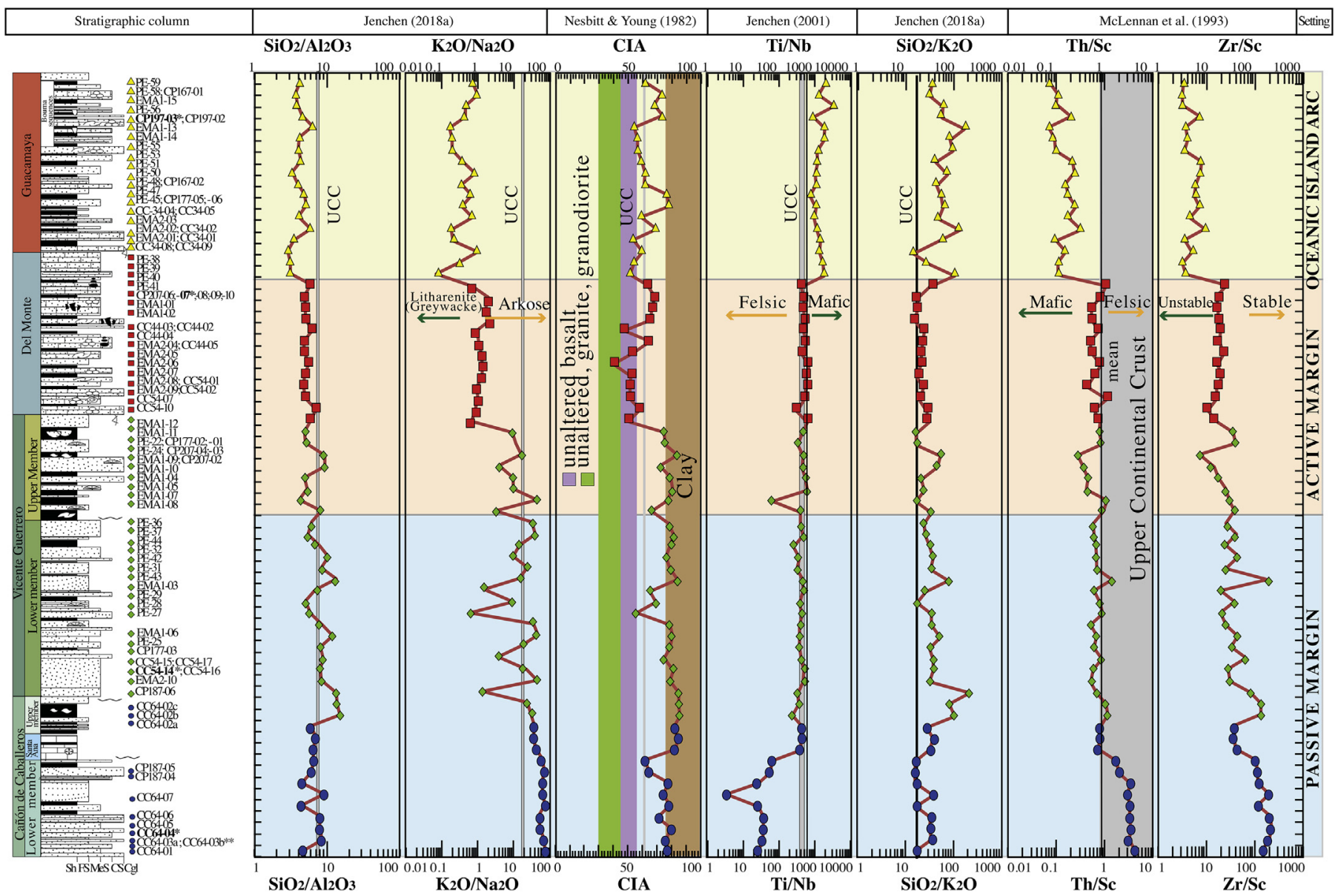

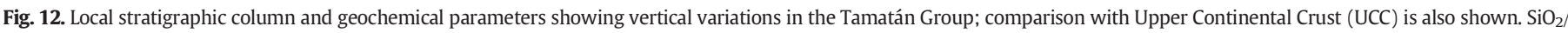
$\mathrm{Al}_{2} \mathrm{O}_{3}, \mathrm{SiO}_{2} / \mathrm{K}_{2} \mathrm{O}$ and $\mathrm{K}_{2} \mathrm{O} / \mathrm{Na}_{2} \mathrm{O}$ (Jenchen, 2018a), CIA (Nesbitt and Young, 1982), Ti/Nb (Bonjour and Dabard, 1991; Jenchen, 2001), Th/Sc and Zr/Sc (McLennan et al., 1993).

et al. (1993), and Jenchen (2018a) for provenance and geotectonic setting, the Cañón de Caballeros samples were constrained in the passive margin field but associated with felsitic geochemical signals (Fig. 8 and Fig. 9). A different source and geotectonic setting for the Cañón de Caballeros may be possible and supported because its relatively different rare earth element patterns $(\mathrm{S}-\mathrm{REE}=315)$ and $(\mathrm{La} / \mathrm{Sm})_{\mathrm{N}}$, $\left(\mathrm{Eu} / \mathrm{Eu}^{*}\right)_{\mathrm{N}}$, and well $(\mathrm{Gd} / \mathrm{Yb})_{\mathrm{N}}$ ratios than the Carboniferous-Permian formations of the Tamatán Basin (Fig. 10). According to the petrographic and geochemical signatures of the Cañón de Caballeros Formation, a felsitic provenance is proposed to be coherent with the abundant quartz, feldspar, and felsite volcanic clasts of the samples.

The youngest zircon population from the Cañón de Caballeros Formation has ages of approximately 442-397 Ma, with a peak age of $426 \pm 2$ (Fig. 11and Fig. 13), which can be interpreted in terms of their maximum depositional age. Hence, from the fourteen youngest zircon grains (412-397 Ma) that overlap in age within $2 \sigma$, a new maximum depositional $\mathrm{U}-\mathrm{Pb}$ age of earliest Devonian for the Cañón de Caballeros Formation, leads to an important adjustment of the pre-existing stratigraphic age for the formation. Boucot et al. (1997) and Stewart et al. (1999) proposed a stratigraphic age of midWenlock (ca. $430 \mathrm{Ma}$ ) to Pridoli (ca. $419 \mathrm{Ma}$ ) age established based on Silurian fossils including rostroconchs, brachiopods, gastropods, bryozoans, corals, ostracods, and potential trilobite fragments. Therefore, the new geochronological data indicate that the age of the Cañón de $\mathrm{Ca}$ balleros Formation extends until the Earliest Devonian, younger as reported by Stewart et al. (1999). The fauna of this formation might be consequently recycled.
The range between 485 and 419 Ma (Ordovician-Silurian ages; Fig. 11 a, and Fig. 13), are equivalent to $36 \%$ of the total zircon spots and could be considered of igneous origin related to the Ordovician-Silurian magmatic belt in the Maya block, namely the Motozintla suite, Chiapas (Estrada-Carmona et al., 2012), the Rabinal suite, Guatemala (Ortega-Obregón et al., 2008), Altos Cuchumatanes, Guatemala (Solari et al., 2010), Mountain Pine Ridge, Belize (Steiner and Walker, 1996; Martens et al., 2010; Weber et al., 2012) and Tamaulipas (Peregrina tonalite; Alemán-Gallardo et al., 2019b). Hence, a close relationship between the Tamaulipas and the southern Maya block (Chiapas, NW Guatemala, and Belize) can be suggested (Fig. 13a). Conversely, the Acatlán complex from the Mixteco Terrane is also reported to be an Ordovician-Silurian bimodal magmatic suite derived from a rifting-drifting tectonic setting (e.g., Piaxtla Suite; Esperanza granitoids; Miller et al., 2007; Keppie et al., 2008, Martini et al., 2020). The paleogeographic positions for the Tamatán Basin during the Ordovician-Early Silurian, might be similar to those proposed for the Mixteco Terrane (e.g., Nance et al., 2007; Keppie et al., 2008; Fig. 13 and Fig. 14). However, and in accordance to Weber et al. (2012), felsitic composition and the Ordovician to Silurian zircon ages ( 485 and $419 \mathrm{Ma}$ ) from the Cañón de Caballeros Formation suggest a major derivation of igneous sources from the Maya block than from the Mixteco Terrane. Thus, the Tamatán Basin was probably located closer to the Maya block along the Gondwanan margin.

The most prominent zircon population of the Cañón de Caballeros Formation, ranging in ages between 1331 and 991 Ma (49\% 

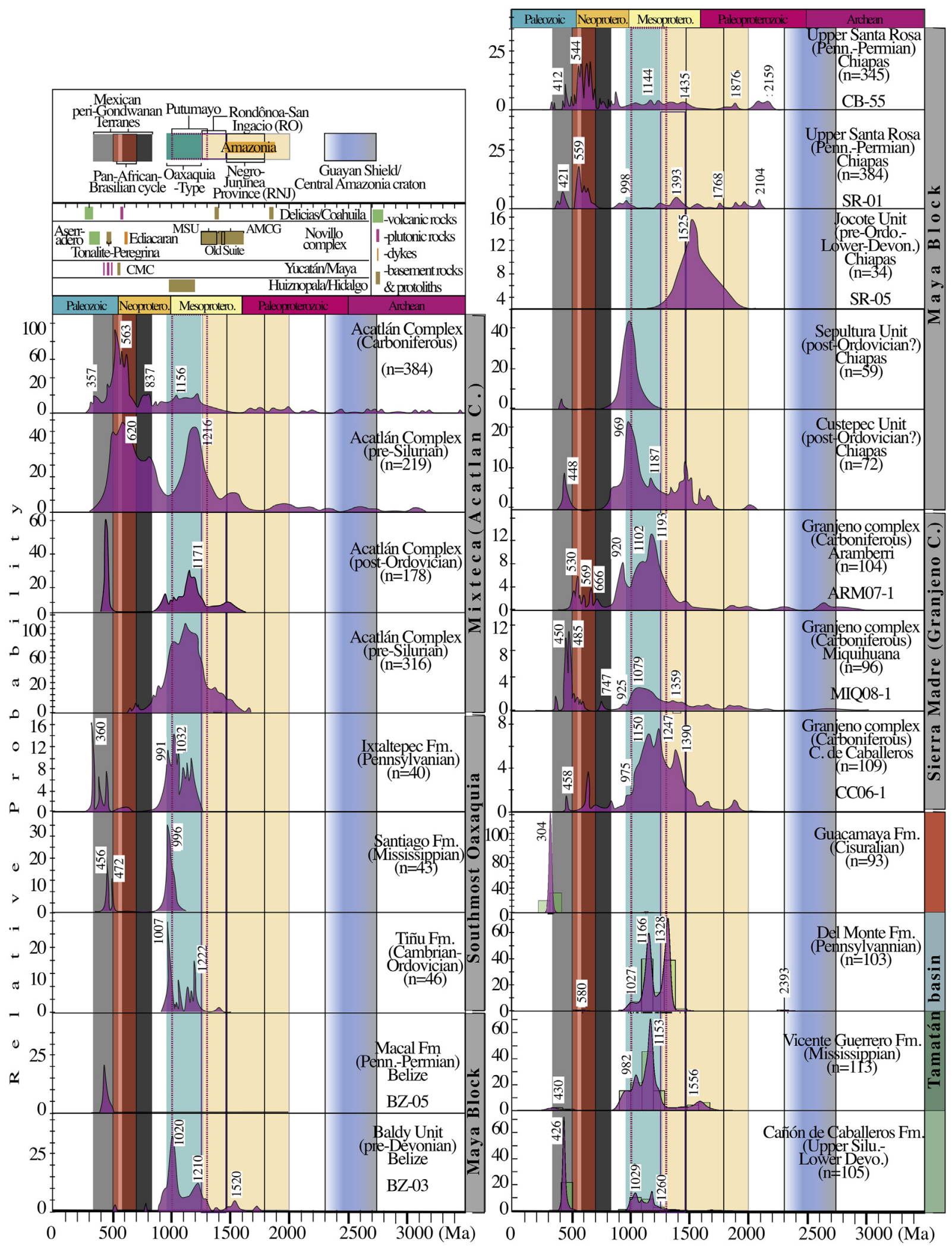

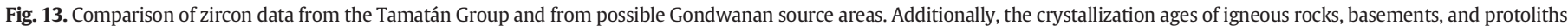
are plotted (references in text). The Maya Block includes data from sedimentary and metasedimentary rocks in Chiapas and Belize (modified from Weber et al., 2008).

from total), can be interpreted as typical for Oaxaquia-type basement (e.g., Cameron et al., 2004; Keppie et al., 2011; Fig. 13; Fig. 15a). Cores dated with $1.7 \mathrm{Ga}$ and $1.4 \mathrm{Ga}$ could be considered from different sources, as there is little to no record of rocks of these ages from eastern South America and West Africa (e.g., Cordani et al., 2005). 


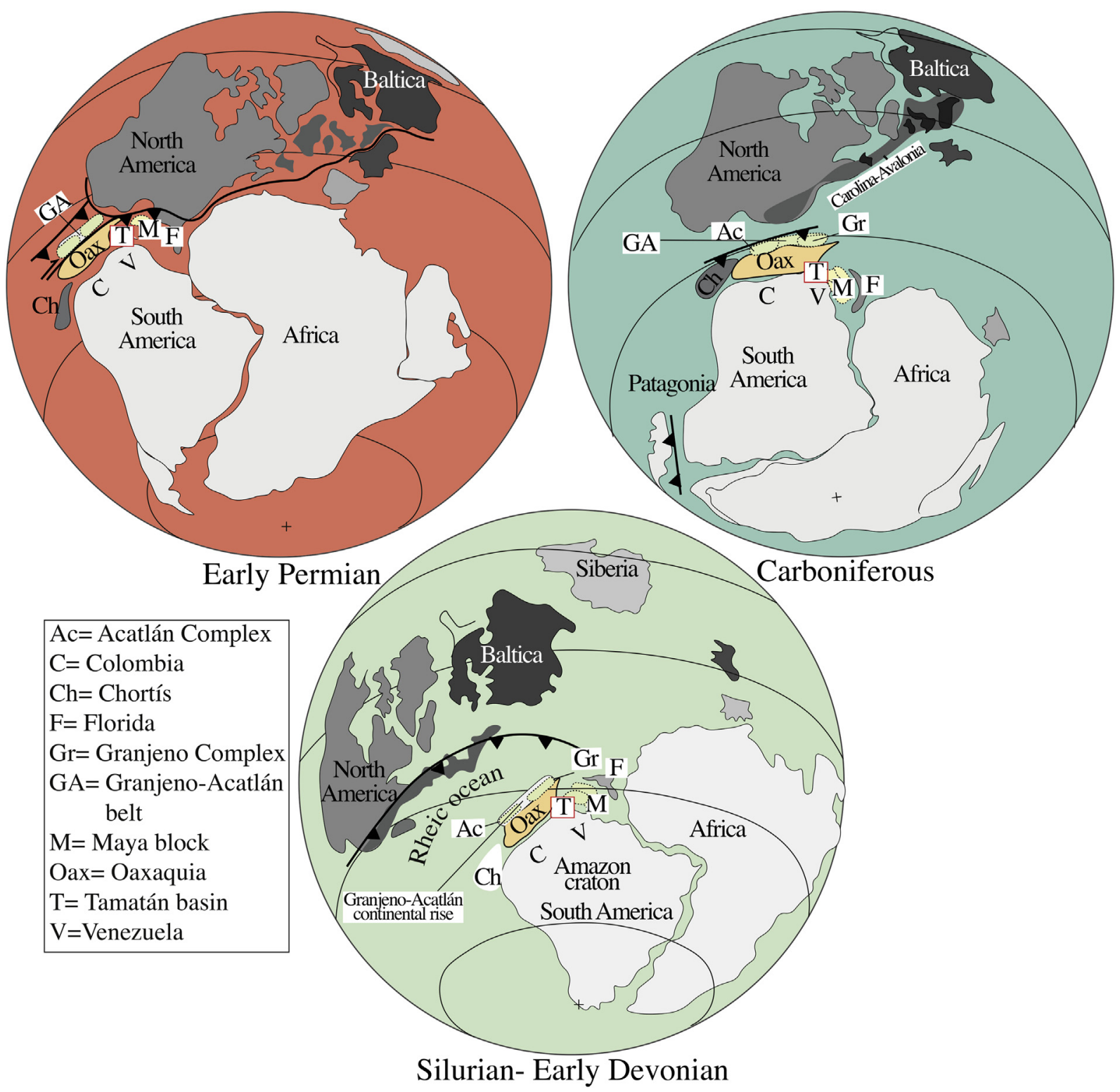

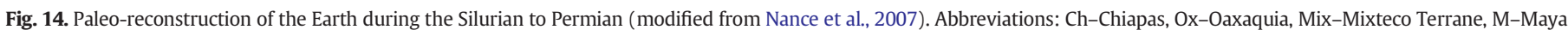
Block, Px-Piaxtla-Suite, F-Florida, GA- Granjeno Acatlán Complex, and T-Tamatán Basin.

\subsubsection{Vicente Guerrero Formation}

The Vicente Guerrero Formation shows similarities in petrographic and geochemical features with the Cañón de Caballeros Formation. For example, the main mineralogical framework is abundant in monocrystalline quartz grains with straight extinction, K-feldspar, micas, high Qmr/Qmo (0.38), and very low P/K (0.05) ratios. However, the Vicente Guerrero Formation also includes abundant polycrystalline quartz ( $\mathrm{Qm} / \mathrm{Qp}=0.34$; e.g., sample EMA1-08; Table 5, Casas-Peña et al., 2021) as well as sedimentary and igneous lithic fragments but scarce in plagioclase (Fig. 6a-b), which can indicate a felsitic (e.g., granitic rocks; sample EMA2-10, Table 7, Casas-Peña et al., 2021) to intermediate sources with contributions from low-grade metamorphic sources of psammitic and pelitic protoliths (e.g., sample EMA1-05,-08, Table 7, Casas-Peña et al., 2021). Coarse-grain samples of the Vicente Guerrero Formation show well-rounded lithic clasts (e.g., sample CP187-06; Table 7, Casas-Peña et al., 2021) of metamorphic, plutonic, and volcanic sedimentary sources (e.g., shell fragments), which suggests that the Vicente Guerrero Formation had a high transport energy. The matrix abundance of illite of these sandstones is still lower than that of the Cañón de Caballeros Formation. Sandstone of the Vicente Guerrero Formation is characterized as litho-feldspatho-quartzose and lithoquartzose (Fig. 6a) (after Garzanti, 2018).

The main mineralogical framework is also traced by the oxides as well high $\mathrm{SiO}_{2}$ (49-85 wt\%), $\mathrm{K}_{2} \mathrm{O}$ (0.36 to $4 \mathrm{wt} \%$ ), and $\mathrm{Al}_{2} \mathrm{O}_{3}$ (5-14 wt $\%$ ) as well low contents of $\mathrm{Na}_{2} \mathrm{O}$ ( 0 to $3 \mathrm{wt} \%$ ), which classifies these rocks in discrimination diagrams as quartz-feldspar sandstone (Fig. 7). The large compositional range depends on the member of the Vicente Guerrero Formation; essentially, the lower member tends to have high $\mathrm{SiO}_{2}$ and $\mathrm{K}_{2} \mathrm{O}$, low $\mathrm{Al}_{2} \mathrm{O}_{3}$, and very low $\mathrm{Na}_{2} \mathrm{O}, \mathrm{CaO}$, and $\mathrm{MgO}$ concentrations, which contrast to the upper member. This is because the upper member has a higher clay content due weathering. Moderate to large transport has been proposed as the dominant sedimentary process, which is reflected by the high CIA and PIA values (76\% and $61 \%$; Fig. 8a) as well as moderate $\mathrm{Th} / \mathrm{Sc}(0.75)$ and $\mathrm{Zr} / \mathrm{Sc}(48)$ ratios (Fig. 8b), which indicates significant transport, recycling, and/or selective sorting of the source (McLennan et al., 1993; Fig. 8b and Fig. 12). 


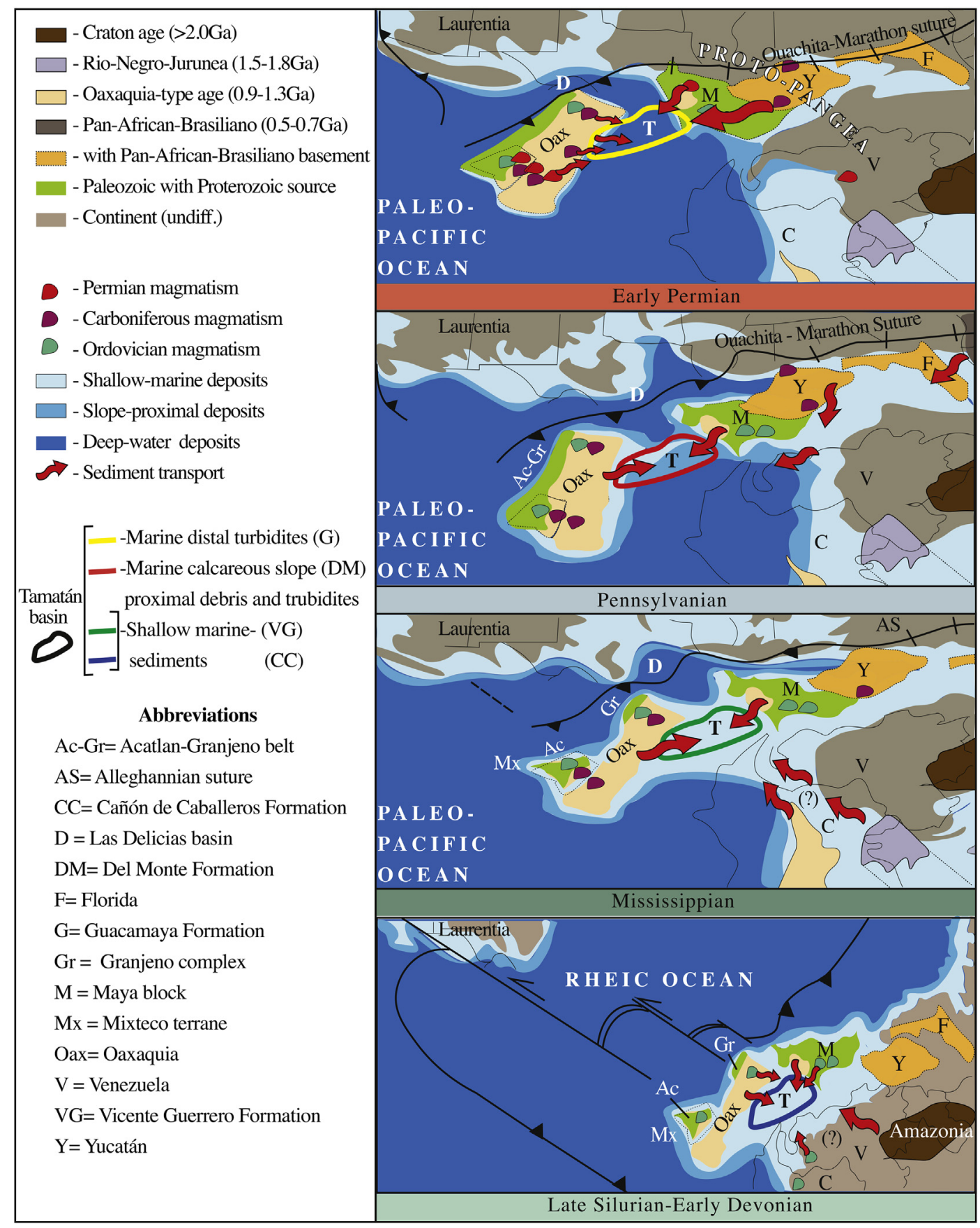

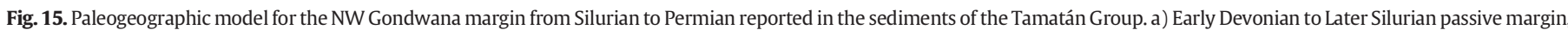
b-c-d) Carboniferous-Permian active margin.

Furthermore, the moderate to large transport can also be supported by the rounded zircon morphologies of the Vicente Guerrero Formation (Fig. 11b).

Likewise, felsitic to intermediate sources for the Vicente Guerrero Formation is plausible (Fig. 8 and Fig. 9) which is supported according to the moderate $\mathrm{Ti} / \mathrm{Nb}$ (385) and high $\mathrm{SiO}_{2} / \mathrm{K}_{2} \mathrm{O}(48)$ ratios as well the $\mathrm{SiO}_{2} / \mathrm{Al}_{2} \mathrm{O}_{3}$ (8.5) and $\mathrm{K}_{2} \mathrm{O} / \mathrm{Na}_{2} \mathrm{O}$ (18.8) ratios (Fig. 9b-c). According to previous discrimination diagrams (e.g., Jenchen, 2018a; Bhatia and Crook, 1986), the Vicente Guerrero Formation indicate a passive continental margin (Fig. 9c-d and Fig. 12). However, and according to traditional paleogeographic models for the Mississippian a passive setting is questionable (e.g., Keppie et al., 2008). Therefore, an active continental margin with a felsitic source is more plausible and is supported by the coincidence of REE patterns as well $\left(\mathrm{La} / \mathrm{Sm}^{*}\right)_{\mathrm{N}},\left(\mathrm{Eu} / \mathrm{Eu}^{*}\right)_{\mathrm{N}}$, and $\left(\mathrm{Gd} / \mathrm{Yb}^{*}\right)_{\mathrm{N}}$ ratios with values for the composites as UCC, PAAS, and NASC (Fig. 10a-b; Taylor and McLennan, 1985).

Two of three Paleozoic zircon grains yielded strongly discordant ages with the third grain yielding an apparent ${ }^{206} \mathrm{~Pb} /{ }^{238} \mathrm{U}$ age of $305 \pm 8 \mathrm{Ma}$, which may indicate the maximum depositional age; however, in the absence of further data analyses of this age (see Table 18 and Table 19, Casas-Peña et al., 2021), this suggestion is not tenable. Hence, it is possible that age variations such as 305 and $308 \mathrm{Ma}$ (Vicente Guerrero 
Formation), as well as 397 and 334 Ma (Cañón de Caballeros Formation), from this Paleozoic age group result from analytical uncertainty or secondary Pb-loss in certain zircon grains.

A group of nine concordant grains between 950 and 911 Ma yielded a weight mean age of $934 \pm 9 \mathrm{Ma}$ (not shown), which is significantly younger than the 990-980 Ma, is typical of granulite facies metamorphic Oaxaquia basement rocks (e.g., Solari et al., 2003). All other zircon grains yielded Precambrian ages ranging from 1680 to $910 \mathrm{Ma}$ (Fig. 11b). The majority of the grains have ages typical for Oaxaquiatype between 1310 and $970 \mathrm{Ma}$, with peaks at $1187 \pm 7$ Ma (47\%) and $1054 \pm 6 \mathrm{Ma}$ (24\%; Fig. 11b).

A group of twelve zircon grains yielded ${ }^{207} \mathrm{~Pb} /{ }^{206} \mathrm{~Pb}$ ages between 1.69 and $1.44 \mathrm{Ga}$, with a peak age of $1.56 \pm 0.01 \mathrm{Ga}$ (Fig. 11b). Such ages are not known from the underlying Novillo Complex (Oaxaquia), which implies different sources for Late Paleoproterozoic to Early Mesoproterozoic zircon grains. For example, in the Maya block (e.g., Weber and Köhler, 1999), Colombia (e.g., Putumayo; IbanezMejia et al., 2011) as well as in the western Amazonia such as Rio Negro-Jurunea province (RNJ) and Rondônoa-San Ignacio provinces (RO; Tassinari et al., 2000; Geraldes et al., 2001; Fig. 13), metasedimentary and igneous rocks have reported zircon ages of 1.6-1.5 Ga. Particularly, in the different units of the Maya Block, e.g., Jocote Unit and the Baldy Formation, similar Paleo- and Mesoproterozoic zircon assemblages are also observed in Fig. 13. Therefore, it is more plausible that the Mississippian Vicente Guerrero Formation maintains a position on the eastern side of the Oaxaquian microcontinent, nearby the Maya block (Fig. 14 and Fig. 15b). Such an interpretation implies that the Maya block and possibly also the Putumayo complex of Colombia were important sources for the Tamatán Basin. Conversely, in the Acatlán complex (Mixteca Terrane), Mesoproterozoic zircon population ages have been reported (e.g., Sánchez-Zavala et al., 2004; Talavera-Mendoza et al., 2005, 2007; Gillis et al., 2005; Morales-Gámez et al., 2008; Fig. 13). Nonetheless, most Acatlán zircon ages are related to local adjacent Oaxaquia sources, and the Carboniferous sedimentary strata from Acatlán and the Maya block include a high proportion of Pan-African-Brazilian zircon ages (Fig. 13). Conversely, such ages are practically unobserved in the Tamatán Group (Fig. 15b).

\subsubsection{Del Monte Formation}

The Pennsylvanian Del Monte Formation samples exhibit a remarkable quantity of perthitic microcline alkaline feldspars and volcanic quartz (e.g., Qmr/Qmo: 0.6) as well as a high P/F (0.4) ratio; igneous lithic-fragments (e.g., sample CP207-08; Table 8, Casas-Peña et al., 2021 ) could indicate an increased contribution from granites, andesites igneous sources, and a dominant signature of magmatic arc influence (Fig. 6). Low-grade metamorphic sources are also suggested owing to the presence of polycrystalline quartz with sutured crystals contacting more than three grains as well metasedimentary lithic fragments (e.g., sample CC54-05; Table 8, Casas-Peña et al., 2021). Local carbonate precipitation from the basin has also been proposed by the high sedimentary bioclastic grains, abundant microfossils, and calcareous cement (Table 8, Casas-Peña et al., 2021). In comparison to the abovementioned formations, the mineralogical influence of plagioclasedominated volcanic inputs is identifiable (Fig. 5 and Fig. 6a-b).

Del Monte Formation samples are considered to be litho-quartzofelspathic (Fig. 6a). The have moderate $\mathrm{SiO}_{2}$ (28-57 wt\%), $\mathrm{K}_{2} \mathrm{O}$ (1-3 wt\%), $\mathrm{Na}_{2} \mathrm{O}$ (1-2 wt\%), $\mathrm{Al}_{2} \mathrm{O}_{3}$ (3.9-11.1 wt\%), and high $\mathrm{CaO}$ (9-35 wt\%) content. Moderate weathering conditions in the source area could be inferred due to low CIA and PIA (56\% and 60\%, respectively) values (Fig. 8a and Fig. 12), which are commonly from cool or arid climate conditions (e.g., Fedo et al., 1995). Direct contributions from primary sources can be inferred from low $\mathrm{Th} / \mathrm{Sc}(0.73)$ and $\mathrm{Zr} / \mathrm{Sc}$ (17.8) ratios (Fig. 12b and Fig. 13), indicating a decrease in the influence of sedimentary processes such as transport, sorting, and reworking (recycling) of the material (e.g., McLennan et al., 1993). The moderate
$\mathrm{Ti} / \mathrm{Nb}$ (500) and low $\mathrm{SiO}_{2} / \mathrm{K}_{2} \mathrm{O}$ (24.2) ratios also indicate that the chemical features from the intermediate source area do not change (Fig. 8 and Fig. 9a-b).

Following Jenchen (2018a) and Bhatia and Crook (1986), the Del Monte Formation samples were plotted in the active margin to subordinate continental island arc fields (Fig. 9c-d), which is plausible due to previous paleogeographic models reported during the Carboniferous (e.g., Keppie et al., 2008). According to the REE patterns and the magnitude of the negatve Eu anomaly from the Del Monte Formation, which are similar to the UCC, PAAS, NASC as well igneous rocks derivate from an active continental setting (for example, Jackson et al., 1995; Ortega-Obregón et al., 2008; Alemán-Gallardo et al., 2019a; Fig. 38; Casas-Peña et al., 2021).

The detrital zircon ages of the Del Monte Formation range from 2394 to $417 \mathrm{Ma}$. Zircon dates between $586 \pm 15 \mathrm{Ma}$ and $575 \pm$ $15 \mathrm{Ma}$, and a minor $580 \mathrm{Ma}$ peak suggest sources from the PanAfrica-Brazilian orogenic cycle (Fig. 11 and Fig. 13). Such ages are less abundant in the Del Monte Formation compared to those reported from the Las Delicias Formation in Coahuila, the Santa Rosa Formation, or similar metasedimentary rocks from the Chiapas Massif Complex (CMC) of the Maya Block (e.g., Lopez et al., 2001; Weber et al., 2006, 2008; Martens et al., 2010). A direct Pan-AfricanBrazilian source for the Pennsylvanian Tamatán deposition area is, however, questionable (Fig. 13).

The inherited zircon ages of the Del Monte Formation (1328 Ma and 1166 Ma peaks; Ectasian and Stenian period, Mesoproterozoic) can be associated with Oaxaquian-type sources (e.g., Keppie and OrtegaGutiérrez, 2010; Keppie et al., 2011). One Paleoproterozoic zircon grain was detected, which might indicate a reworked cratonic source similarly to those observed in the Pennsylvanian Santa Rosa Formation (Weber et al., 2006, 2009; Fig. 11and Fig. 13).

\subsubsection{Guacamaya Formation}

The Guacamaya Formation is dominated by a notable content of $\mathrm{K}$ and Na-feldspar $(P / F=0.48)$ and igneous phenocrysts of quartz, feldspar, mica, and lathwork texture from volcanic lithic grains, suggesting a mix of sources from mafic and felsitic rocks (Fig. 6a-b). In particular, the samples were fed by rhyolitic, andesitic, and gabbroic volcanic rocks (e.g., sample EMA1-14, Table 9, Casas-Peña et al., 2021) and plutonic rocks of granitic and granodioritic compositions (e.g., CC34-07, Table 9, Casas-Peña et al., 2021). Most of the Guacamaya Formation can be characterized based on major oxides features according to varieties of pelitic to psammitic rocks, enriched-carbonates sandstone, and Na-feldspar rich sandstones (Fig. 7a-b and Fig. 12).

Low CIA and PIA (60\% and 61\%, respectively) indicate moderate weathering conditions. The low transport energy and non-recycled material is indicated by the low $\mathrm{Th} / \mathrm{Sc}(0.15)$ and $\mathrm{Zr} / \mathrm{Sc}$ (4.7) ratios (McLennan et al., 1993; Fig. 8b), which is also notable due to the unaltered crystal habit of the Pennsylvanian-Permian zircons (Fig. 11d). The dominance of intermediate to mafic volcanism can be distinguished (e. g., Fig. 8a-b) and supported by a relatively high Ti/Nb (1373.3) and $\mathrm{SiO}_{2} / \mathrm{K}_{2} \mathrm{O}$ (70.3) ratio (Fig. 9a-b; Jenchen, 2018a). Like the Del Monte Formation, the Guacamaya Formation is associated with a magmatic arc (Fig. 5c-d), which is also supported because REE patterns are similar to magmatic rocks associated with arc systems (e.g., Fig. 9d), the increase in LREE (2.1), and decrease in HREE (1.4) with a slight Euanomaly as well the $\left(\mathrm{La} / \mathrm{Sm}^{*}\right)_{\mathrm{N}},\left(\mathrm{Eu} / \mathrm{Eu}^{*}\right)_{\mathrm{N}}$, and $\left(\mathrm{Gd} / \mathrm{Yb}^{*}\right)_{\mathrm{N}}$ ratios also suggest an Upper Continental Crust provenance (Fig. 10; Bhatia, 1985; Taylor and McLennan, 1985). Therefore, given the petrography and geochemical signatures, a magmatic arc tectonic setting may correspond to the main source area of the clastic components shown in the Guacamaya Formation (Fig. 6c-d), which is also supported by REE patterns (Fig. 10) as well the relationship obtained by applying the ThCo-Zr/10 and La- Th- Sc ternary diagrams after Bhatia and Crook (1986) for sedimentary clastic rock (Fig. 9d and Fig. 12). Most of the Guacamaya Formation samples plot within the oceanic island arc field 
in these diagrams. In contrast, the current Permian paleogeographic models for the Mexican peri-Gondwanan terranes correspond to a constantly diachronous closure of the Rheic Ocean and the collision of Gondwana against Laurentia (e.g., Coombs et al., 2020).

The geochronological zircon population record from the Guacamaya Formation ranged from $1130 \pm 41$ Ma to $279 \pm 9$ Ma. Most zircon ages yield in Late Pennsylvanian to Early Permian ages with notable sequential ages that probably indicate continuity of crystallization ages for magmatic sources (Table 22, Casas-Peña et al., 2021). A well-defined peak age at $303 \mathrm{Ma}(2 \mathrm{\sigma}$; Fig. 11d) suggests that the contemporaneous igneous sources are relatively close to the study area. Plutonic rocks with similar ages were reported from the Gulf of Mexico coast drill cores of Tamaulipas (294-274 Ma, Coombs et al., 2020), from the Chiapas Massif Complex (orthogneiss protolith, $272 \pm 3 \mathrm{Ma}$, Weber et al., 2007) and from the Mixteco terrane (Totoltepec pluton, 306-287 Ma; Yañez et al., 1991; Keppie, 2004; Kirsch et al., 2012). Therefore, during the Late Carboniferous to early Permian, the Tamatán Basin received a probable contribution from these igneous systems (Fig. 14and Fig. 15d). In contrast, a maximum depositional age from the Cisuralian (Early Permian) for the Guacamaya Formation is suggested, due to the least ten younger concordant grains, which is consistent with its stratigraphic age (Stewart et al., 1999).

Slightly older zircon grains in the range from 331 to $301 \mathrm{Ma}$ (52 spots) most probably have their sources from igneous rocks related to Late Carboniferous arc magmatism along northwestern Gondwana as reported from the Chicxulub impact site ( $325 \mathrm{Ma}$; Zhao et al., 2020)), the Altos Cuchumatanes, Guatemala ( 317 Ma, Solari et al., 2010) or more locally from the Aserradero Rhyolite ( 334 Ma, Stewart et al., 1999). A minor group from two spots aged $1130 \pm$ $41 \mathrm{Ma}$ and $1130 \pm 40 \mathrm{Ma}$ can be inferred as typical from the Oaxaquia source (Fig. 13).

\subsection{Tectonic implications for the Tamatán Basin and the closure of the Rheic Ocean}

Considering the published models and our new age data for the Tamatán Basin, a more coherent development history is proposed (Fig. 15). According to the petrography and geochemical signatures in the Cañón de Caballeros Formation felsitic rocks are associated to a passive margin setting (Fig. 15a). This scenario has only been documented in southern Mexican terranes for the Ordovician to Early Silurian (e.g., Nance et al., 2006; Keppie et al., 2007, 2008), where it is inferred that rifting and drifting moved along the northwestern Gondwanan margin, leading to the opening to the Rheic Ocean by separating Avalonia from the northwestern margin Gondwanan margin and, consequently, to the closure of the Iapetus Ocean by the collision of Avalonia with Laurentia (Nance et al., 2012).

In the Mixteca terrane is influenced by bimodal rift-related magmatism intruded clastic passive margin sediments (Keppie et al., 2008) whose age of emplacement spans ca. 485-440 Ma (e.g., Piaxtla suite and Esperanza granitoids, Miller et al., 2007; Morales-Gámez et al., 2008: Fig. 2). However, evidence for a passive margin in the Tamatán Basin is indicated by the here presented new geochemical data (Fig. 9). Therefore, the final stage of a passive margin for the Cañón de Caballeros Formation can be inferred (Fig. 15a). Weber et al. (2012) postulated that the rift-drift scenario in the Early Paleozoic was coupled with uplift and erosion of the Mesoproterozoic basement (Oaxaquia, Colombia Andes, and other Oaxaquia-Type blocks) attached to northwestern Amazonia in a basin and range regime (Fig. 15a). This is consistent with the abundance of Mesoproterozoic zircon grains in the Cañón de Caballeros Formation as well from Maya block for this time, which may have originated from local sources as a result of eroding Oaxaquia basement (Fig. 13).

Abundant Ordovician-Silurian continental arc-related magmatism not only in the Colombian and Venezuelan Andes (e.g., van der Lelij et al., 2016; Tazzo-Rangel et al., 2019) but also in the Maya Block
(Motozintla, Rabinal, Altos Cuchumatanes, Mountain Pine Ridge; e.g. Estrada-Carmona et al., 2012) and in Tamaulipas (Peregrina Tonalite) suggest northwestern extension of the Famatinian magmatic arc (Weber et al., 2018; Alemán-Gallardo et al., 2019a) and ongoing subduction during the early Paleozoic in that regions. At least in the Maya Block, there is no evidence for Ordovician-Silurian rifting and opening of the Rheic Ocean, instead, rifting occurred during the Ediacaran opening of the Iapetus Ocean (González-Guzmán et al., 2016; Weber et al., 2020).

In Mexico, these magmatic intrusions could be exhumed during the Silurian age for the presence of Middle-Upper Ordovician age zircon in metasedimentary rocks such as the Granjeno Complex that includes a peak age of $450 \mathrm{Ma}$ (Barboza-Gudiño et al., 2011; Fig. 13). Although the geochemical discrimination for the tectonic setting (Fig. 9) conflicts with this alternative model, the igneous lithic fragment components (Fig. 6), felsitic geochemical composition (Fig. 12), and age-Ordovician provenance (Fig. 10) of the Cañón de Caballeros Formation indicates that the source probably comes also from for these magmatic bodies. The Bladen unit in the Maya Mountains of Belize contains sandstones and conglomerates with granitic rock pebbles and interbedded rhyolite tuff dated at $406 \mathrm{Ma}$ (Martens et al., 2010). It is associated with a shallow-marine basin, which can be analogous to the Tamatán Basin in the Silurian-Early Devonian (Martens et al., 2005, 2010; Fig. 15) and a correlation with the Cañón de Caballeros Formation can be inferred from the Oaxaquia-type detrital zircon ages.

Both marginal basins developed between the Paleozoic continental crust of Oaxaquia and the passive margin along the cratonic side of Gondwana. Such a geologic scenario accounts for Ordovician-Silurian igneous rocks from local northernmost Oaxaquia as the proximity of the Tamatán Basin with the Mayan block (Fig. 15a).

A change in the tectonic scenario from the passive to convergent margin is inferred but the exact time is questionable due to deposition lack during approximately 50 Ma between the Silurian-Early Devonian. This is also suggested by an overall absence of Middle Devonian to Early Carboniferous detrital zircons. Along the northwestern Gondwanan margin, an active continental arc was established during the initial stage of the diachronic closure of the Rheic Ocean and the collision of Laurentia and Gondwana (Nance et al., 2012; Fig. 15b-c). Clastic and calcareous successions of the Carboniferous from the Tamatán Basin were deposited in a back-arc region. The Vicente Guerrero and Del Monte formations also suggest a change from felsitic to intermediate source rocks probably associated with a change in tectonic setting as well the proximity of Laurentia and Gondwana. Therefore, the Carboniferous magmatic arc in peri-Gondwanan terranes contributed to the igneous detritus for the Tamatán Basin, which is suggested by the volcanic components as well the moderate values of $\mathrm{Th} / \mathrm{Sc}$ and $\mathrm{Ti} / \mathrm{Nb}$. Metamorphic components are likely derived from Novillo or Granjeno complexes according to the lithic fragments, geochemical composition, and NeoMesoproterozoic provenance age. Hence, the Tamatán Basin, together with other Mexican peri-Gondwanan terrenes (i.e., Coahuila terrane, Maya block; McKee et al., 1999; Weber et al., 2006) were located at the northwestern Gondwana margin during the Late Carboniferous by a zipper-type collision with Laurentia during the Ouachita-MarathonSonora Orogeny (ca. 320 to 280 Ma; Hatcher, 2002; Fig. 15b-c).

During this period, a volcanic continental arc developed in northwestern Gondwana as represented by the Aserradero Rhyolite erupting at ca. $334 \mathrm{Ma}$ (Stewart et al., 1999). This igneous body is likely located in a more internal continental area near the back-arc Tamatán Basin because the rhyolitic lavas are interbedded with the Carboniferous clastic successions as Vicente Guerrero and Del Monte formations. For the Late Carboniferous to Early Permian (ca. $300 \mathrm{Ma}$ ), emplacement of the Granjeno Complex has been suggested (Dowe et al., 2005). Similarly the Acatlán Complex records contemporaneous juxtaposition against the Oaxaca complex along the Caltepec fault (Elías-Herrera and Ortega-Gutiérrez, 2016). Hence, it is plausible to suggest a genetic 
relation between Caltepec fault and the contact between Granjeno Complex and Tamatán Basin sediments and its basement.

The development of deep flysch sediments in the Tamatán Basin is interpreted to have occurred during the Early Permian. The petrography and geochemical signatures indicate felsitic and mafic sources, which can be derived from the Permian arc. Coombs et al. (2020) pointed out that the Permian magmatism developed in three magmatic phases, each of which formed in different stages from the oceanic plate in the same tectonic setting, such as (1) Early Permian (294-274 Ma) granitoids associated with a continental arc formed on the margin of Gondwana during the closure of the Rheic Ocean, prior to the final amalgamation of Pangea; (2) Late Permian-Early Triassic (263-243 Ma) granitoids with supra-subduction affinity formed by crustal anatexis, related to coeval granitoids in southernmost Oaxaquia and Chiapas Massif; and (3) Early-Middle Jurassic (189-164 Ma) mafic porphyries related to synchronous supra-subduction magmatism for the Nazas arc (post-orogenic magmatism). The Guacamaya Formation shows evidences of a 280 Ma magmatism similar to the first phase, which is suggestive of the arc system from mantle-derived melts mixing with continental crust, whereas younger pulses were not observed. However, the geochemical signature is different from the typical arc system in which the high $\mathrm{Ti} / \mathrm{Nb}$ and very low $\mathrm{Th} / \mathrm{Sc}$ suggest mafic sources related to oceanic and continental island arcs (Fig. 9). Such findings may be questionable according to established models, but we suggest that this setting can be a possible relict from an island arc, which can also be observed in other localities, as reported by Rosales-Lagarde et al. (2005) in the Tuzancoa Formation.

During the final stage of the back arc, Tamatán Basin was closed and deformed by the collision of Laurentia against Gondwanan; however, the Tamatán Basin was only affected by deformation but not by metamorphism, as the field observation in the Guacamaya Formations beds indicate (see Fig. 6, Casas-Peña et al., 2021). Concurrently, the volcanism was continuously active until the Triassic prior to the Pangea breakup (e.g., Coombs et al., 2020), and a cordilleran magmatism in the Permian-Triassic occurred from the Sonora (Sierra Pinta; Arvizu et al., 2009) to central (Gulf Coast Plain; Coombs et al., 2020) and southern Mexico (Chiapas Massif, Maya block; Weber et al., 2007) and the northwestern Andes (e.g., Cochrane et al., 2014). Plutonic rocks with similar ages were reported from the Gulf of Mexico coast drill cores of Tamaulipas (294-274 Ma, Coombs et al., 2020), from the Chiapas Massif Complex (orthogneiss protolith, $272 \pm 3 \mathrm{Ma}$, Weber et al., 2007) and from the Mixteco terrane (Totoltepec pluton, 306-287 Ma; Yañez et al., 1991; Keppie, 2004; Kirsch et al., 2012).

\section{Conclusions}

The mineralogical, geochemical, and geochronological variations observed in the Tamatán Group reveal the progressive evolution of a passive margin to a active continental margin. The paleogeographic reconstruction of the region can be described as follows (see Fig. 15):

- Contrasting effects from source composition and sedimentary rocks can be distinguished. This confirms that the Tamatán Group exhibits considerable variation: (i) the older Cañón de Caballeros and Vicente Guerrero formations reveal high $\mathrm{Zr} / \mathrm{Sc}$ ratios and sedimentary recycling with stable mineral additions (e.g., zircon, apatite, tourmaline, quartz, etc.); (ii) the Del Monte and Guacamaya formations reveal moderate to low $\mathrm{Zr} / \mathrm{Sc}$ ratios with lower addition of stable minerals.

- The Cañón de Caballeros Formation was deposited in a marginal basin following the Ordovician-Silurian magmatic arc setting from the periGondwanan margin between the Upper Silurian and the Lower Devonian, showing a high affinity to Oaxaquian source areas and influence from Maya Block sources. A connection to the Rheic Ocean was confirmed by the presence of Gondwanan Silurian fauna (Fig. 15a).

- An increasing influence of zircons probably derived from with the Maya Block in the Vicente Guerrero Formation suggests a connection between the Tamatán deposition area and the Maya Block (e.g., 1.5-1.6 Ga; Jocote unit; Fig. 13). However, for both localities, an affinity for Oaxaquia is also essential (Fig. 13b). This affinity was reinforced during the deposition period of the Pennsylvanian Del Monte Formation. Moreover, a possible first erosion of the Novillo Complex can be postulated based on the $1328 \mathrm{Ma}$ and 1166 Ma peak ages (Fig. 15c).

- The geochemical and sedimentological features of the Guacamaya Formation are markedly different from those of the other Tamatán sedimentary units. These characteristics may indicate the influence of an oceanic island arc system.

\section{Supporting data in}

Casas-Peña et al. (in proc.) $\rightarrow$ Casas-Peña, J.M., Ramírez-Fernández, J.A., Velasco-Tapia, F., Alemán-Gallardo, E.A., Augustsson, C., Weber, B., Frei, D. \& Jenchen, U. (en prep.): Petrological, geochemical (major-, trace-, and rare earth element) and U-Pb zircon data of the Tamatán Basin, NE Mexico. - Data in Brief.

\section{Credit author Statement}

Juan Moisés Casas-Peña $\rightarrow$ Investigation; Methodology; Formal analysis; Writing - Original Draft

Juan Alonso Ramírez-Fernández $\rightarrow$ Conceptualization; Methodology; Project administration

Fernando Velasco-Tapia $\rightarrow$ Methodology; Formal analysis

Eduardo Alejandro Alemán-Gallardo $\rightarrow$ Investigation

Carita Augustsson $\rightarrow$ Conceptualization; Formal analysis

Bodo Weber $\rightarrow$ Methodology; Data Curation; Formal analysis

Dirk Frei $\rightarrow$ Data Curation

Uwe Jenchen $\rightarrow$ Conceptualization; Methodology; Writing - Review \& Editing; Project administration; Funding acquisition

\section{Declaration of Competing Interest}

The authors declare that they have no known competing financial interests or personal relationships that could have appeared to influence the work reported in this paper.

\section{Acknowledgments}

Financial support for this work was provided by a Ph.D. scholarship for the first author from the National Council of Science and Technology (CONACYT; CVU: 630722) The first author, who is Ph.D. student at the postgraduate program of the Facultad de Ciencias de la Tierra, Universidad Autónoma de Nuevo León (FCT/UANL), would like to thank Sergio Padilla-Ramírez, Susana Rosas-Montoya and Daniela Tazzo (Centro de Investigación Científica y de Educación Superior de Ensenada B.C., CICESE) for assistance during the preparation and analysis of the geochronological data. Special thanks to L.A. Elizondo-Pacheco; N.Z. Morales-Alemán; D.C. Rodríguez-Campero y M. Rodríguez-Escamilla (FCT/UANL) for their support during field work. The authors specially thank R. Damian Nance, Michelangelo Martini, and Roberto Molina Garza for the revision, their helpfully comments and support to finish this document. The geochemical and geochronological analyses were financed by the PAICyT (Programa de Apoyo a la Investigación Científica y Tecnológica) projects CT-129-09 and CN-940-19, granted by the Universidad Autónoma de Nuevo León.

\section{References}

Alemán-Gallardo, E., Ramírez Fernández, J.A., Rodríguez Díaz, A., Velasco-Tapia, F., Jenchen, U., Cruz-Gámez, E., Navarro-de León, I., Leon-Barragán, L., 2019a. Evidence for an Ordovician continental arc in the pre-Mesozoic basement of the HuizachalPeregrina Anticlinorium, Sierra Madre Oriental, Mexico: the Peregrina Tonalite. Mineral. Petrol. 113 (4), 433-562. https://doi.org/10.1007/s00710-019-00660-4. 
Alemán-Gallardo, E.A., Ramírez-Fernández, J.A., Weber, B., Velasco-Tapia, F., Juan Moisés Casas-Peña, J.M., 2019b. Novillo Metamorphic Complex, Huizachal-Peregrina Anticlinorium, Tamaulipas, Mexico: Characterization and development based on whole-rock geochemistry and Nd-isotopic ratios. J. S. Am. Earth Sci. 96 (102382), $1-17$.

Arvizu, H.E., Iriondo, A., Izaguirre, A., Chávez-Cabello, G., Kamenov, G.D., Solís-Pichardo, G., Foster, D.A. \& Lozano-Santa Cruz, R, 2009. Rocas graníticas pérmicas en la Sierra Pinta, NW de Sonora, México: Magmatismo de subducción asociado al inicio del margen continental activo del SW de Norteamérica. Revista Mexicana de Ciencias Geológicas 26 (3), 709-728.

Bahlburg, H., 1998. The geochemistry and provenance of Ordovician turbidites in the Argentine Puna. In: Pankhurst, R.J., Rapela, C.W. (Eds.), The proto-Andean margin of Gondwana. - Geological Society Special Publications. 142, pp. 127-142.

Barboza-Gudiño, J.R., Ramírez-Fernández, J.A., Torres-Sánchez, S.A., Valencia, V.A., 2011. Geocronología de circones detríticos de diferentes localidades del Esquisto Granjeno en el noreste de México. Bol. Soc. Geol. Mex. 63 (2), 201-216.

Bellizzia, A., Pimentel, N., 1994. Terreno Mérida: Un cinturón alóctono herciniano en la Cordillera de Los Andes de Venezuela. - in: Proceedings, V Simposio Bolivariano de Exploración Petrolera en las Cuencas Subandinas, Sociedad Venezolana de Geólogos: 271-290; Puerto La Cruz. Venezuela. https://doi.org/10.3997/2214-4609pdb.116.037esp.

Bhatia, M.R., Crook, K.A.W., 1986. Trace element characteristics of graywackes and tectonic setting discrimination of sedimentary basins. Contrib. Mineral. Petrol. 92, $181-193$.

Bhatia, M.R., 1985. Rare Earth Element geochemistry of Australian Paleozoic graywackes and mudrocks: provenance and tectonic control. Sediment. Geol. 45, 97.

Bonjour, J.L., Dabard, M.P., 1991. Ti/Nb ratios of clastic terrigenous sediments used as an indicator of provenance. Chem. Geol. 91 (3), 257-267.

Borradaile, G.J., 2003. Statistics of Earth Science Data: Their Distribution in Time, Space and Orientation. Springer, Berlin, Heidelberg, p. 351

Boucot, A.J., Blodggett, R.B., Stewart, J.H., 1997. European Province Late Silurian brachiopods from the Ciudad Victoria area, Tamaulipas, northeastern Mexico. In: Klapper, G., Murphy, M.A., Talent, J.A. (Eds.), Paleozoic sequence stratigraphy, biostratigraphy, and biogeography: Studies in honor of J. Granville ("Jess") Johnson. - GSA Special Paper. 321, pp. 273-293.

Boucot, A.J., Benedetto, J.L., Grahn, Y., Melo, J.H.G., Sanchez, T.M., Waisfeld, B.A., 1999. South American marine Silurian communities. In: Boucot, A.J., Lawson, J.D. (Eds.), Paleocommunities: A case study from the Silurian and Lower Devonian. Cambridge University Press, pp. 841-848.

Bouma, A.H., 1962. Sedimentology of some flysch deposits, a graphic approach to facies interpretation. Elsevier, Amsterdam, p. 168

Cameron, K.L., Lopez, R., Ortega-Gutiérrez, F., Solari, L.A., Keppie, J.D., Schulze, C., 2004. U$\mathrm{Pb}$ geochronology and $\mathrm{Pb}$ isotopic compositions of leached feldspars: Constraints on the origin and evolution of Grenville rocks from eastern and southern Mexico. In: Tollo, R.P., Corriveau, L., McLelland, J., Bartholomew, M.J. (Eds.), Proterozoic tectonic evolution of the Grenville orogen in North America. 197, pp. 755-769 GSA Memoir.

Campa, M.F., Coney, P.J., 1983. Tectono-stratigraphic terranes and mineral resource distributions in Mexico. Can. J. Earth Sci. 20 (6), 1040-1051.

Carrillo-Bravo, J., 1961. Geología del Anticlinorio Huizachal-Peregrina al NW de Ciudad Victoria. Tamps. - Boletín de la Asociación Mexicana de Geólogos Petroleros 13 (1/2), 1-98.

Casas-Peña, Juan Moisés; Ramírez-Fernández, Juan Alonso; Velasco-Tapia, Fernando; Alemán-Gallardo, Eduardo Alejandro; Augustsson, Carita; Weber, Bodo; Frei, Dirk; Jenchen, Uwe (2021), "Complete data set of petrological, geochemical (major, trace, and rare earth elements), and U-Pb zircon analysis from the Tamatán Group, NE Mexico", Mendeley Data, V1, doi: https://doi.org/10.17632/wbzzy6hcgj.1.

Centeno-García, E., 2005. Review of Upper Paleozoic and Lower Mesozoic stratigraphy and depositional environments of central and west Mexico: Constraints on terrane analysis and paleogeography. In: Anderson, T.H., Nourse, J.A., McKee, J.W., Steiner, M.B. (Eds.), The Mojave-Sonora megashear hypothesis: Development, assessment, and alternatives. 393. GSA Special Paper, pp. 233-258. https://doi.org/10.1130/ 2005.2393(08).

Centeno-García, E., Mendoza-Rosales, C.C., Silva-Romo, G., 2009. Sedimentología de la Formación Matzitzi (Paleozoico superior) y significado de sus componentes volcánicos, región de Los Reyes Metzontla-San Luis Atolotitlán. Estado de Puebla. Revista Mexicana de Ciencias Geológicas 26 (1), 18-36.

Chew, D.M., Schaltegger, U., Košler, J., Whitehouse, M.J., Gutjahr, M., Spikings, R.A., Aleksandar Mišković, A., 2007. U-Pb geochronologic evidence for the evolution of the Gondwanan margin of the north-central Andes. GSA Bull. 119 (5/6), 697-711. https://doi.org/10.1130/B26080.1].

Cisneros-de León, A., Weber, B., Ortega-Gutiérrez, F., González-Guzmán, R., Maldonado, R., Solari, L., Schaaf, P., Manjarrez-Juárez, R., 2017. Grenvillian massif-type anorthosite suite in Chiapas, Mexico: Magmatic to polymetamorphic evolution of anorthosites and their Ti-Fe ores. - Precambrian Research 295, 203-226. https://doi.org/ 10.1016/j.precamres.2017.04.028.

Clemons, R.E., Burkart, B., 1971. Stratigraphy of Northwestern Guatemala. Bol. Soc. Geol. Mex. 32, 143-158.

Cochrane, R., Spikings, R., Gerdes, A., Ulianov, A., Mora, A., Villagómez, D., Putlitz, B., Chiaradia, M., 2014. Permo-Triassic anatexis, continental rifting and the disassembly of western Pangaea. Lithos 190-191, 383-402. https://doi.org/10.1016/j. lithos.2013.12.020.

Condie, K.C., 1993. Chemical composition and evolution of the upper continental crust; contrasting results from surface samples and shales. Chem. Geol. 104 (1-4), 1-37.

Coombs, H.E., Kerr, A.C., Pindell, J., Buchs, D., Weber, B., Solari, L., 2020. Petrogenesis of the crystalline basement along the western Gulf of Mexico: Postcollisional magmatism during the formation of Pangea. In: Martens, U., Molina-Garza, R.S. (Eds.), Southern and Central Mexico: Basement Framework, Tectonic Evolution, and Provenance of Mesozoic-Cenozoic Basins. 546. GSA Special Paper, pp. 1-24. https://doi.org/ 10.1130/2020.2546(02)

Cordani, U.G., Cardona, A., Jimenez, D.M., Liu, D., Nutman, A.P., 2005. Geochronology of Proterozoic basement inliers in the Colombian Andes: Tectonic history of remnants of a fragmented Grenville belt. In: Vaughan, A.P.M., Leat, P.T., Pankhurst, R.J. (Eds.), Terrane Processes at the Margins of Gondwana. - The Geological Society of London. 246. Special Publications, pp. 329-346.

Cunningham, K.D., 1975. Petrology and petrography of Permian volcanogenic and carbonate rocks near Las Delicias, Coahuila, Mexico. M.S. Thesis. Forth Worth Texas Christian University, Forth Worth Texas, p. 72.

Damon, P.E., Shafiqullah, M., Clark, K., 1981. Age trends of igneous activity in relation to metallogenesis in the southern Cordillera. In: Dickinson, W., Payne, W.D. (Eds.), Relations of Tectonics to Ore Deposits in the Southern Cordillera. -Arizona Geological Society Digest. 14, pp. 137-153 Tucson, Arizona.

Dickinson, W.R., Lawton, T.F., 2001. Carboniferous to Cretaceous assembly and fragmentation of Mexico. GSA Bull. 113, 1142-1160.

Dickinson, W.R., Suczek, C.R., 1979. Plate tectonics and sandstone composition. AAPG Bull. 63 (12), 2164-2182.

Dickinson, W.R., 1985. Interpreting provenance relations form detrital modes of sandstones. In: Zuffa, G.G. (Ed.), Provenance of Arenites. - NATO ASI Series C. 148. D. Riedel, Dordrecht, pp. 333-361.

Dickinson, W.R., Beard, L.S., Brakenridge, G.R., Erjavec, J.L., Ferguson, R.C., Inman, K.F., Knepp, R.A., Lindberg, F.A., Ryberg, R.T., 1983. Provenance of North American Phanerozoic sandstones in relation to tectonic setting. GSA Bull. 94 (2), 222-235.

Dowe, D.S., Nance, R.D., Keppie, J.D., Cameron, K.L., Ortega-Rivera, A., Ortega-Gutiérrez, F., Lee, J.W.K., 2005. Deformational History of the Granjeno Schist, Ciudad Victoria, Mexico: Constraints on the Closure of the Rheic Ocean? Int. Geol. Rev. 47 (9), 920-937. https://doi.org/10.2747/0020-6814.47.9.920].

Elías-Herrera, M., Ortega-Gutiérrez, F., 2016. Caltepec fault zone: An Early Permian dextral transpressional boundary between the Proterozoic Oaxacan and Paleozoic Acatlán complexes, southern Mexico, and regional tectonic implications. Tectonics 21 (3), $4,1-4,18$.

Esquivel-Macías, C., Solís-Marín, F., Buitrón-Sánchez, B.E., 2004. New records of Upper Paleozoic crinoids columnar plates (Echinodermata, Crinoidea) from Upper Paleozoic of Mexico, some paleobiogeographic and paleoenvironmental implications. Coloquios de Paleontología 54, 15-23.

Estrada-Carmona, J., Weber, B., Martens, U., López-Martínez, M., 2012. Petrogenesis of Ordovician magmatic rocks in the southern Chiapas Massif Complex: relations with the early Palaeozoic magmatic belts of northwestern Gondwana. Int. Geol. Rev. 54 (16), 1918.

Estrada-Carmona, J., Solari, L.A., Ortega-Obregón, C., 2016. Petrochronology of the migmatization event of the Xolapa Complex, Mexico, microchemistry and equilibrium growth of zircon and garnet. Int. Geol. Rev. 58 (11), 1382-1397.

Fedo, C.M., Nesbitt, H.W., Young, G.M., 1995. Unraveling the effects of potassium metasomatism in sedimentary rocks and Paleosols, with implications for paleoweathering conditions and provenance. Geology 23 (10), 921-924.

Fitz-Díaz, E., Lawton, T.F., Juárez-Arriaga, E., Chávez-Cabello, G., 2018. The CretaceousPaleogene Mexican orogen: Structure, basin development, magmatism and tectonics. Earth Sci. Rev. 183, 56-84. https://doi.org/10.1016/j.earscirev.2017.03.002].

Flawn, P.T., Diaz, T., 1959. Problems of Paleozoic Tectonics in North-Central and Northeastern Mexico. AAPG Bull. 43 (1), 224-230.

Frei, D., Gerdes, A., 2009. Precise and accurate in situ U-Pb dating of zircon with high sample throughput by automated LA-SF-ICP-MS. Chem. Geol. 261 (3-4), 261-270. https://doi.org/10.1016/j.chemgeo.2008.07.025].

García, C.A., Ríos, C.A., Castellanos, O.M., 2005. Medium-pressure metamorphism in the Central Santander Massif, Eastern Cordillera. Colombian Andes. - Boletín de Geología 27 (2), 43-68.

Garzanti, E., 2016. From static to dynamic provenance analysis - Sedimentary petrology upgraded. Sediment. Geol. 336, 3-13. https://doi.org/10.1016/j.sedgeo.2015.07.010].

Garzanti, E., 2018. Petrographic classification of sand and sandstone. Earth Sci. Rev. 192, 545-563. https://doi.org/10.1016/j.earscirev.2018.12.014].

Geraldes, M.C., van Schmus, W.R., Condie, K.C., Bell, S., Teixeira, W., Babinski, M., 2001. Proterozoic geologic evolution of the SW part of the Amazonian Craton in Mato Grosso state. Brazil. - Precambrian Research 111 (1-4), 91-128. https://doi.org/ 10.1016/s0301-9268(01)00158-9].

Gerdes, A., Zeh, A., 2006. Combined U-Pb and Hf isotope LA-(MC-)ICP-MS analyses of detrital zircons: Comparison with SHRIMP and new constraints for the provenance and age of an Armorican metasediment in Central Germany. Earth Planet. Sci. Lett. 249 (1-2), 47-61. https://doi.org/10.1016/j.epsl.2006.06.039].

Gerdes, A., Zeh, A., 2009. Zircon formation versus zircon alteration - New insights from combined U-Pb and Lu-Hf in-situ LA-ICP-MS analyses, and consequences for the interpretation of Archean zircon from the Central Zone of the Limpopo Belt. Chem. Geol. 261 (3-4), 230-243. https://doi.org/10.1016/j.chemgeo.2008.03.005.

Gillis, R.J., Gehrels, G.E., Ruiz, J., Flores de Dios-Gonzaléz, L.A, 2005. Detrital zircon provenance of Cambrian-Ordovician and Carboniferous strata of the Oaxaca terrane, southern Mexico. Sediment. Geol. 182 (1-4), 87-100.

Girty, G.H., 1926. A new area of Carboniferous rocks in Mexico. Science 63 (1628), 286-287.

González de Juana, C., Iturralde de Arosemena, J.M., Picard-Cadillat, X., 1980. Geología de Venezuela y de sus cuencas petrolíferas. Caracas (Ediciones Foninves), p. 407.

González-Guzmán, R., Weber, B., Manjarrez-Juárez, R., Cisneros de León, A., Hecht, L., Herguera-García, J.C., 2016. Provenance, age constraints and metamorphism of Ediacaran metasedimentary rocks from the El Triunfo Complex (SE Chiapas, México): evidence for Rodinia breakup and Iapetus active margin. Int. Geol. Rev. 58 (16), 2065-2091. https://doi.org/10.1080/00206814.2016.1207208]. 
Gromet, L.P., Dymek, R.F., Haskin, L.A., Korotev, R.L., 1984. The "North American shale composite": Its compilation, major and trace element characteristics. Geochim. Cosmochim. Acta 48, 2469-2482.

Gursky, H.J., Michalzik, D., 1989. Lower Permian turbidites in the northern Sierra Madre Oriental, Mexico. - Zentralblatt fuer Geologie und Palaeontologie, Teil I: Allgemeine, Angewandte. Regionale und Historische Geologie 1989 (5-6), 821-838.

Gursky, H.J., 1996. Paleozoic stratigraphy of the Peregrina Canyon area, Sierra Madre Oriental, NE Mexico. - Zentralblatt für Geologie und Paläontologie, Teil I: Allgemeine, Angewandte. Regionale und Historische Geologie 1994 (7-8), 973-989.

Harnois, L., 1988. The CIW index: A new chemical index of weathering. Sediment. Geol. 55 (3-4), 319-322. https://doi.org/10.1016/0037-0738(88)90137-6].

Hernández-García, R., 1973. Paleogeografía del Paleozoico de Chiapas. México. - Boletín de la Asociación Mexicana de Geólogos Petroleros 25, 79-113.

Ibanez-Mejia, M., Ruiz, J., Valencia, V.A., Cardona, A., Gehrels, G.E., Mora, A.R., 2011. The Putumayo Orogen of Amazonia and its implications for Rodinia reconstructions: New U-Pb geochronological insights into the Proterozoic tectonic evolution of northwestern South America. Precambrian Res. 191 (1-2), 58-77. https://doi.org/10.1016/ j.precamres.2011.09.005].

Ingersoll, R.V., Suczek, C.A., 1979. Petrology and provenance of Neogene sand from Nicobar and Bengal fans, DSDP sites 211 and 218. J. Sediment. Res. 49 (4), 1217-1228.

Jackson, T.A., Duke, M.J.M., Scott, P.W., Smith, F., Wilkinson, F.C.F., 1995. Petrology and Inferred Tectonic Setting of the Mountain Pine Ridge Granitoids, Maya Mountains, Belize. Int. Geol. Rev. 37 (1), 26-38.

Jackson, S.E., Pearson, N.J., Griffin, W.L., Belousova, E.A., 2004. The application of laser ablation-inductively coupled plasma-mass spectrometry to in situ U-Pb zircon geochronology. Chem. Geol. 211 (1-2), 47-69.

Jenchen, U., Rosenfeld, U., 2007. Geochemical investigations as a tool to sedimentary analyses demonstrated in Argentinean continental Triassic sediments: Methods and aspects. Neues Jb. Geol. Paläontol. Abh. 246 (1), 37-61. https://doi.org/10.1127/ 0077-7749/2007/0246-0037].

Jenchen, U., 2001. Fazies und Geochemie in kontinentalen Trias-Becken im westlichen Argentinien und in Patagonien $\left(30^{\circ}-50^{\circ}\right)$. Münstersche Forschungen zur Geologie und Paläontologie 91, 441.

Jenchen, U., 2018a. Petrography and geochemistry of the Triassic El Tranquilo Group, Deseado Massif, Patagonia, Argentina: Implications for provenance and tectonic setting. J. S. Am. Earth Sci. 88, 530-550.

Jenchen, U., 2018b. Petrological and geochemical (major-, trace-, and rare earth element) data of the Triassic El Tranquilo Group, Deseado Massif, Patagonia, Argentina. Data in Brief 21, 1970-2014.

Keppie, J.D., Ortega-Gutiérrez, F., 2010. 1.3-0.9 Ga Oaxaquia (Mexico): Remnant of an arc/ backarc on the northern margin of Amazonia. J. S. Am. Earth Sci. 29, 21-27.

Keppie, J.D., 2004. Terranes of Mexico revisited; a 1.3 billion year odyssey. Int. Geol. Rev. 46 (9), 765-794. https://doi.org/10.2747/0020-6814.46.9.765].

Keppie, J.D., Nance, R.D., Fernández-Suárez, J., Storey, C.D., Jeffries, T.E., Murphy, J.B., 2006. Detrital Zircon Data from the Eastern Mixteca Terrane, Southern Mexico: Evidence for an Ordovician-Mississippian Continental Rise and a Permo-Triassic Clastic Wedge Adjacent to Oaxaquia. Int. Geol. Rev. 48 (2), 97-111. https://doi.org/10.2747/00206814.48.2.97].

Keppie, J.D., Dostal, J., Elías-Herrera, M., 2007. Ordovician-Devonian oceanic basalts in the Cosoltepec Formation, Acatlán Complex, southern México: Vestiges of the Rheic Ocean? In: Linnemann, U., Nance, R.D., Kraft, P., Zulauf, G. (Eds.), The evolution of the Rheic Ocean: From Avalonian-Cadomian active margin to Alleghenian-Variscan collision. 423. GSA Special Paper, pp. 477-487. https:// doi.org/10.1130/2007.2423(24)

Keppie, J.D., Dostal, J., Murphy, J.B., Nance, R.D., 2008. Synthesis and tectonic interpretation of the westernmost Paleozoic Variscan orogen in southern Mexico: From rifted Rheic margin to active Pacific margin. Tectonophysics 461 (1-4), 277-290. https:// doi.org/10.1016/j.tecto.2008.01.012].

Keppie, J.D., Murphy, J.B., Nance, D.R., Dostal, J., 2011. Mesoproterozoic Oaxaquia-type basement in peri-Gondwanan terranes of Mexico, the Appalachians, and Europe: $\mathrm{T}_{\mathrm{DM}}$ age constraints on extent and significance. Int. Geol. Rev. 2011, 1-12.

Kirsch, M., Keppie, J.D., Murphy, J.B., Solari, L.A., 2012. Permian-Carboniferous arc magmatism and basin evolution along the western margin of Pangea: Geochemical and geochronological evidence from the eastern Acatlán Complex, southern Mexico. GSA Bull. 124 (9/10), 1607-1628. https://doi.org/10.1130/B30649.1].

Kirsch, M., Keppie, J.D., Murphy, J.B., Lee, J.K.W., 2013. Arc plutonism in a transtensional regime: the late Palaeozoic Totoltepec pluton, Acatlán Complex, southern Mexico. Int. Geol. Rev. 55 (3), 263-286. https://doi.org/10.1080/00206814.2012.693247].

Krogh, T.E., Kamo, S.L., Bohor, B.F., 1993a. Fingerprinting the K/T impact site and determining the time of impact by U Pb dating of single shocked zircons fromdistal ejecta. Earth Planet. Sci. Lett. 119, 425-429.

Krogh, T.E., Kamo, S.L., Sharpton, V.L., Marin, L.E., Hildebrands, A.R., 1993b. U/Pb ages of single shocked zircons linking distal K/T ejecta to the Chicxulub crater. Nature 366, 731-734.

Lawton, T.F., Sierra-Rojas, M.I., Martens, U., 2020. Stratigraphic correlation chart of Carboniferous-Paleogene rocks of Mexico, adjacent southwestern United States, Central America, and Colombia. In: Martens, U., Molina-Garza, R.S. (Eds.), Southern and Central Mexico: Basement Framework, Tectonic Evolution, and Provenance of Mesozoic-Cenozoic Basins. 546. GSA Special Paper, p. 28. https://doi.org/10.1130/ 2020.2546(05)

Laya, J.C., Tucker, M.E., 2012. Facies analysis and depositional environments of Permian carbonates of the Venezuelan Andes: Palaeogeographic implications for Northern Gondwana. Palaeogeogr. Palaeoclimatol. Palaeoecol. 331-332, 1-26. https://doi.org/ 10.1016/j.palaeo.2012.02.011.
Lopez, R., Cameron, K.L., Jones, N.W., 2001. Evidence for Paleoproterozoic, Grenvillian, and Pan-African age Gondwanan crust beneath northeastern Mexico. Precambrian Res. $107,195-214$.

Ludwig, K.R., 2012. User's Manual for Isoplot 4.1: A Geochronological Toolkit for Microsoft Excel. 5. Berkeley Geochronology Center, Special Publication, Berkeley, CA, p. 75.

Marsaglia, K.M., 1991. Provenance of sand and sandstones from a rifted continental arc, Gulf of California, Mexico. In: Fisher, R.V., Smith, G.A. (Eds.), Sedimentation in Volcanic Settings: Society for Economic Paleontologists and Mineralogist. 45. Special Publication, pp. 237-248. https://doi.org/10.2110/pec.91.45.0237.

Martens, U., Ratschbacher, L., McWilliams, M., 2005. U/Pb geochronology of the Maya block, Guatemala: Eos (Transactions, American Geophysical Union), 86: Fall meeting supplement, abstract T51D-1387.

Martens, U., Weber, B., Valencia, V.A., 2010. U/Pb geochronology of Devonian and older Paleozoic beds in the southeastern Maya block, Central America: Its affinity with peri-Gondwanan terranes. GSA Bull. 122 (5/6), 815-829. https://doi.org/10.1130/ B26405.1].

Martínez-Sánchez, L.E., 2016. Estudio geológico, geoquímico y geocronológico del Granito Maxala, del magmatismo carbonífero de México (Hidalgo y Veracruz). - Tesis que para obtener el título de Ingeniero Geólogo, Escuela Superior de Ingeniería y Arquitectura. Instituto Politécnico Nacional, Ticomán, Ciudad de México, México, p. 165.

Martini, M., Solari, L., Peña-Guerrero, M., Zepeda-Martínez, M., Montomoli, C., 2020. Guidelines for assessing the provenance of Mesozoic and Cenozoic clastic successions sourced by pre-Jurassic basement complexes in southernmost North America. J. Sediment. Res. 90, 513-532. https://doi.org/10.2110/jsr.2020.30].

McKee, J.W., Jones, N.W., Anderson, T.H., 1999. Late Paleozoic and early Mesozoic history of the Las Delicias terrane, Coahuila, Mexico. In: Bartolini, C., Wilson, J.L., Lawton, T.F. (Eds.), Mesozoic Sedimentary and Tectonic History of North-Central Mexico. 340. GSA Special Paper, pp. 161-189. https://doi.org/10.1130/0-8137-2340-X.161.

McLennan, S.M., Hemming, S., McDaniel, D.K., Hanson, G.N., 1993. Geochemical approaches to sedimentation, provenance, and tectonics. In: Johnsson, J., Basu, A. (Eds.), Processes controlling the composition of clastic sediments. 284. GSA Special Paper, pp. 21-40.

Miller, B.V., Dostal, J., Keppie, J.D., Nance, R.D., Ortega-Rivera, A., Lee, J.K.W., 2007. Ordovician calc-alkaline granitoids in the Acatlán Complex, southern México: Geochemical and geochronologic data and implications for the tectonics of the Gondwanan margin of the Rheic Ocean. In: Linnemann, U., Nance, R.D., Kraft, P., Zulauf, G. (Eds.), The evolution of the Rheic Ocean: From Avalonian-Cadomian active margin to AlleghenianVariscan collision. 423. GSA Special Paper, pp. 465-475.

Morales-Gámez, M., Keppie, J.D., Norman, M., 2008. Ordovician-Silurian rift-passive margin on the Mexican margin of the Rheic Ocean overlain by Carboniferous-Permian periarc rocks: Evidence from the eastern Acatlán Complex, southern Mexico. Tectonophysics 461 (1-4), 291-330.

Nance, R.D., Miller, B.V., Keppie, J.D., Murphy, J.B., Dostal, J., 2006. Acatlán Complex, southern Mexico: Record spanning the assembly and breakup of Pangea. Geology 34 (10), 857-860.

Nance, R.D., Fernández-Suárez, J., Keppie, J.D., Storey, C., Jeffries, T.E., 2007. Provenance of the Granjeno Schist, Ciudad Victoria, México: Detrital zircón U-Pb age constraints and implications for the Paleozoic paleogeography of the Rheic Ocean. In: Linnemann, U., Nance, R.D., Kraft, P., Zulauf, G. (Eds.), The evolution of the Rheic Ocean: From Avalonian-Cadomian active margin to Alleghenian-Variscan collision. 423. GSA Special Paper, pp. 453-464.

Nance, R.D., Gutiérrez-Alonso, G., Keppie, J.D., Linnemann, U., Murphy, J.B., Quesada, C., Strachan, R.A., Woodcock, N.H., 2012. A brief history of the Rheic Ocean. Geosci. Front. 3 (2), 125-135.

Nasdala, L., Corfu, F., Valley, J.W., Spicuzza, M.J., Wu, F.Y., Li, Q.L., Yang, Y.H., Fisher, C., Münker, C., Kennedy, A.K., Reiner, P.W., Kronz, A., Wiedenbeck, M., Wirth, R., Chanmuang, C., Zeug, M., Váczi, T., Norberg, N., Häger, T., Kröner, A. \& Hofmeister, W. (2016): Zircon M127 - A reference material for U-Pb combined with hafnium, oxygen and, potentially, lithium isotope analysis. - Geostand. Geoanal. Res., 40 (4): $457-$ 475. - [doi: 10.1111/ggr.12123]

Navarro-Santillán, D., Sour-Tovar, F., Centeno-García, E., 2002. Lower Mississippian (Osagean) brachiopods from the Santiago Formation, Oaxaca, Mexico: stratigraphic and tectonic implications. J. S. Am. Earth Sci. 15 (3), 327-336. https://doi.org/ 10.1016/S0895-9811(02)00047-0].

Nesbitt, H.W., Young, G.M., 1982. Early Proterozoic climates and plate motions inferred from major element chemistry of lutites. Nature 299, 715-717.

Ortega-Gutiérrez, F., 1978. El Gneis Novillo y rocas metamórficas asociadas en los cañones del Novillo y de la Peregrina, área de Ciudad Victoria, Tamaulipas. Revista del Instituto de Geología, Universidad Nacional Autónoma de México 2 (1), 19-30.

Ortega-Gutiérrez, F., Ruíz, J., Centeno-García, E., 1995. Oaxaquia, a Proterozoic microcontinent accreted to North America during the late Paleozoic. Geology 23 (12), 1127-1130.

Ortega-Gutiérrez, F., Solari, L.A., Ortega-Obregón, C., Elías-Herrera, M., Martens, U., Morán-Ical, S., Chiquín, M., Keppie, J.D., Torres-de León, R., Schaaf, P., 2007. The Maya-Chortís boundary: A tectonostratigraphic Approach. Int. Geol. Rev. 49, 996-1024. https://doi.org/10.2747/0020-6814.49.11.996.

Ortega-Gutiérreza, F., Elías-Herrera, M., Morán-Zenteno, D.J., Solari, L., Weber, B., LunaGonzáleza, L., 2018. The pre-Mesozoic metamorphic basement of Mexico, 1.5 billion years of crustal evolution. Earth Sci. Rev. 183, 2-37. https://doi.org/10.1016/j. earscirev.2018.03.006.

Ortega-Obregón, C., Solari, L.A., Keppie, J.D., Ortega-Gutiérrez, F., Solé, J., Morán-Ical, S. 2008. Middle-Late Ordovician magmatism and Late Cretaceous collision in the southern Maya block, Rabinal-Salamá area, central Guatemala: Implications for North America-Caribbean plate tectonics. GSA Bull. 120 (5/6), 556-570. https://doi.org/ 10.1130/B26238.1] 
Ortega-Obregón, C., Solari, L., Gómez-Tuena, A., Elías-Herrera, M., Ortega-Gutiérrez, F. Macías-Romo, C., 2014. Permian-Carboniferous arc magmatism in southern Mexico: U-Pb dating, trace element and Hf isotopic evidence on zircons of earliest subduction beneath the western margin of Gondwana. Internationa Journal of Eart Sciences (Geologische Rundschau) 103 (5), 1287-1300.

Pemberton, G., MacEachern, J.A., 1992. Trace Fossil Facies Models: Environmental and Allostratigraphic Significance. In: Walker, R.G., James, N.P. (Eds.), Facies Models: Response to Sea Level Change. - Geological Association of Canada GeoText 1, Newfoundland: 47-72.

Pettijohn, F.J., 1963. Chemical composition of sandstones: excluding carbonate and volcanic sands: data of geochemistry. - U.S. Geological Survey 440 (S), 1-21.

Poole, F.G., Perry, W.J., Madrid, R.J., Amaya-Martínez, R., 2005. Tectonic synthesis of the Ouachita-Marathon-Sonora orogenic margin of southern Laurentia: Stratigraphic and structural implications for timing of deformational events and plate-tectonic model. In: Anderson, T.H., Nourse, J.A., McKee, J.W., Steiner, M.B. (Eds.), The Mojave-Sonora megashear hypothesis: Development, assessment, and alternatives GSA Special Paper, 393: 543-596. - [doi: 10.1130/2005.2393(21)]

Ramírez-Fernández, J.A., Jenchen, U., 2016. Cinturones orogénicos sepultados bajo la Sierra Madre Oriental: basamento precámbrico y paleozoico. Ciencia UANL 80, 56-62.

Ramírez-Ramírez, C., 1992. Pre-Mesozoic geology of Huizachal-Peregrina Anticlinorium, Ciudad Victoria, Tamaulipas, and adjacent parts of eastern Mexico. PhD Dissertation. The University of Texas at Austin, Austin, TX, p. 317.

Rosales-Lagarde, L., Centeno-García, E., Dostal, J., Sour-Tovar, F., Ochoa-Camarillo, H., Quiroz-Barroso, S., 2005. The Tuzancoa Formation: Evidence of an Early Permian Submarine Continental Arc in East-Central Mexico. Int. Geol. Rev. 47, 901-919.

Sánchez-Zavala, J.L., Centeno-García, E., Ortega-Gutiérrez, F., 1999. Review of Paleozoic stratigraphy of México and its role in the Gondwana-Laurentia connections. In: Ramos, V.A., Keppie, J.D. (Eds.), Laurentia-Gondwana Connections before Pangea GSA Special Paper, 336: 211-226.

Sánchez-Zavala, J.L., Ortega-Gutiérrez, F., Keppie, J.D., Jenner, G.A., Belousova, E., MaciásRomo, C., 2004. Ordovician and Mesoproterozoic Zircons from the Tecomate Formation and Esperanza Granitoids, Acatlán Complex, Southern Mexico: Local Provenance in the Acatlán and Oaxacan Complexes. Int. Geol. Rev. 46 (11), 1005-1021. https:// doi.org/10.2747/0020-6814.46.11.1005].

Sedlock, R.L., Ortega-Gutierrez, F., Speed, R.C., 1993. Tectonostratigraphic Terranes and Tectonic Evolution of Mexico. 278. GSA Special Paper, Boulder, CO, p. 153.

Sláma, J., Košler, J., Condon, D.J., Crowley, J.L., Gerdes, A., Hanchar, J.M., Horstwood, M.S.A., Morris, G.A., Nasdala, L., Norberg, N., Schaltegger, U., Schoene, B., Tubrett, M.N., Whitehouse, M.J., 2008. Plešovice zircon - A new natural reference material for U$\mathrm{Pb}$ and Hf isotopic microanalysis. Chem. Geol. 249 (1-2), 1-35. https://doi.org/ 10.1016/j.chemgeo.2007.11.005].

Solari, L.A., Dostal, J., Ortega-Gutiérrez, F., Keppie, J.D., 2001. The 275 Ma arc-related La Carbonera stock in the northern Oaxacan Complex of southern Mexico: U-Pb geochronology and geochemistry. Revista Mexicana de Ciencias Geológicas 18 (2), 149-161.

Solari, L.A., Keppie, J.D., Ortega-Gutiérrez, F., Cameron, K.L., Lopez, R., Hames, W.E., 2003. 990 and 1100 Ma Grenvillian tectonothermal events in the northern Oaxacan Complex, southern Mexico: roots of an orogen. Tectonophysics 365 (1-4), 257-282. https://doi.org/10.1016/s0040-1951(03)00025-8].

Solari, L.A., Ortega-Gutiérrez, F., Elías-Herrera, M., Gómez-Tuena, A., Schaaf, P., 2010. Refining the age of magmatism in the Altos Cuchumatanes, western Guatemala, by LA-ICPMS, and tectonic implications. Int. Geol. Rev. 52 (9), 977-998. https://doi. org/10.1080/00206810903216962].

Sour-Tovar, F., Martínez-Chacón, M.L., 2004. Braquiópodos chonetoideos del Carbonífero de México. [Chonetoidea (Brachiopoda) from the Carboniferous of Mexico.]. Revista Española de Paleontología 19 (2), 125-138.

Sour-Tovar, F., Álvarez, F., Martínez Chacón, M.L., 2005. Lower Mississippian (Osagean) spire-bearing Brachiopods from Cañón de la Peregrina, North of Ciudad Victoria, Tamaulipas, northeastern México. J. Paleontol. 79 (3), 469-485. https://doi.org/ 10.1666/0022-3360(2005)079<0469:LMOSBF>2.0.CO;2.

Spikings, R., Cochrane, R., Villagomez, D., Van der Lelij, R., Vallejo, C., Winkler, W., Beate, B., 2015. The geological history of northwestern South America: from Pangaea to the early collision of the Caribbean Large Igneous Province (290-75Ma). Gondwana Res. 27 (1), 95-139. https://doi.org/10.1016/j.gr.2014.06.004].

Steiner, M.B., Walker, J.D., 1996. Late Silurian plutons in Yucatan. J. Geophys. Res. Solid Earth 101 (B8), 17727-17735.

Stewart, J.H., Blodgett, R.B., Boucot, A.J., Carter, J.L., Lopez, R., 1999. Exotic Paleozoic strata of Gondwanan provenance near Ciudad Victoria, Tamaulipas, Mexico. In: Ramos, V.A., Keppie, J.D. (Eds.), Laurentia-Gondwana connections before Pangea GSA Special Paper, 336: 227-252.

Talavera-Mendoza, O., Ruiz, J., Gehrels, G.E., Meza-Figueroa, D.M., Vega-Granillo, R., Campa-Uranga, M.F., 2005. U-Pb geochronology of the Acatlán Complex and implications for the Paleozoic paleogeography and tectonic evolution of southern Mexico. Earth Planet. Sci. Lett. 235 (3-4), 682-699. https://doi.org/10.1016/j. epsl.2005.04.013].

Talavera-Mendoza, O., Ruiz, J., Gehrels, G.E., Valencia, V.A., Centeno-Garcia, E., 2007. Detrital zircon U/Pb geochronology of southern Guerrero and western Mixteca arc successions (southern Mexico): New insights for the tectonic evolution of southwestern North America during the late Mesozoic. GSA Bull. 119 (9-10), 1052-1065. https:// doi.org/10.1130/b26016.1].

Tassinari, C.C.G., Bettencourt, J.S., Geraldes, M.C., Macambira, M.J.B., Lafon, J.M., 2000. The Amazonian craton. In: Cordani, U.G., Milani, E.J., Thomaz, A. (Eds.), Tectonic Evolution of South America. - 31st International Geological Congress, Rio de Janeiro, Brazil, pp. 41-95.

Taylor, S.R., McLennan, S.M., 1985. The Continental Crust: its composition and evolution. Blackwell, Oxford, p. 190
Tazzo-Rangel, M.D., Weber, B., González-Guzmán, R., Valencia, V.A., Frei, D., Schaaf, P. Solari, L.A., 2018. Multiple metamorphic events in the Palaeozoic Mérida Andes basement, Venezuela: insights from U-Pb geochronology and Hf-Nd isotope systematics. Int. Geol. Rev. 61 (13), 1557-1593.

Torres-Martínez, M.A., Sour-Tovar, F., 2016. Braquiópodos discínidos (Lingulida, Discinoidea) de la Formación Ixtaltepec, Carbonífero del área de Santiago Ixtaltepec, Oaxaca. Bol. Soc. Geol. Mex. 68 (2), 313-321.

Torres-Sánchez, S.A., Augustsson, C., Barboza-Gudiño, R., Abratis, M., Ramírez-Fernández, J.A., 2015. Basamento paleozoico de la Sierra Madre Oriental: condiciones metamórficas de P-T en la presencia de fengita y clorita. Ciencia UANL 18 (75), 47-53.

Torres-Sánchez, S.A., Augustsson, C., Barboza-Gudiño, J.R., Jenchen, U., RamírezFernández, J.A., Abratis, M., Scherstén, A., 2016. Magmatic source and metamorphic grade of metavolcanic rocks from the Granjeno Schist: was northeastern Mexico a part of Pangaea? Geol. J. 51, 845-863.

Torres-Sánchez, S.A., Augustsson, C., Jenchen, U., Barboza-Gudiño, J.R., Alemán-Gallardo, E., Ramírez-Fernández, J.A., Torres-Sánchez, D., Abratis, M., 2017. Petrology and geochemistry of meta-ultramafic rocks in the Paleozoic Granjeno Schist, northeastern Mexico: Remnants of Pangaea ocean floor. Open Geosciences 9 (1), 361-384.

Trainor, R.J., Nance, R.D., Keppie, J.D., 2011. Tectonothermal history of the Mesoproterozoic Novillo Gneiss of eastern Mexico: support for a coherent Oaxaquia microcontinent. Revista Mexicana de Ciencias Geológicas 28 (3), 580-592.

Tucker, M.E., 2011. Sedimentary Rocks in the Field: A Practical Guide. 4th ed. Wiley-Blackwell, West Sussex, U.K, p. 276.

Urueña-Suárez, C.L., Zuluaga, C.A., 2011. Petrografía del Neis de Bucaramanga en cercanías a Cepitá, Berlín y Vetas - Santander [Petrography of the Bucaramanga Gneiss near to Cepita, Berlin and Vetas - Santander]. Geología Colombiana 36 (1), 37-56.

Vachard, D., Flores de Dios, A., Buitrón, B., 2004. Guadalupian and Lopingian (Middle and Late Permian) deposits from Mexico and Guatemala, a review with new data. Geobios 37 (1), 99-115. https://doi.org/10.1016/j.geobios.2003.02.002].

van der Lelij, R., Spikings, R., Ulianov, A., Chiaradia, M., Mora, A., 2016. Palaeozoic to Early Jurassic history of the northwestern corner of Gondwana, and implications for the evolution of the Iapetus, Rheic and Pacific Oceans. Gondwana Res. 31, 271-294. https://doi.org/10.1016/j.gr.2015.01.01].

Vermeesch, P., 2018. IsoplotR: A free and open toolbox for geochronology. Geosci. Front. 9 (5), 1479-1493.

Vinasco, C.J., Cordani, U.G., González, H., Weber, W., Pelaez, C., 2006. Geochronological, isotopic, and geochemical data from Permo-Triassic granitic gneisses and granitoids of the Colombian Central Andes. J. S. Am. Earth Sci. 21 (4), 355-371. https://doi. org/10.1016/j.jsames.2006.07.007].

Walker, R.G., Plint, A.G., 1992. Wave- and Storm-Dominated Shallow Marine Systems. In: Walker, R.G., James, N.P. (Eds.), Facies Models: Response to Sea Level Change Geological Association of Canada, GeoText 1, Newfoundland: 219-238.

Weber, B., Köhler, H., 1999. Sm-Nd, Rb-Sr and U-Pb geochronology of a Grenville Terrane in Southern Mexico: origin and geologic history of the Guichicovi Complex. Precambrian Res. 96 (3-4), 245-262. https://doi.org/10.1016/S0301-9268(99)00012-1].

Weber, B., Schulze, C.H., 2014. Early Mesoproterozoic (>1.4 Ga) ages from granulite basement inliers of SE Mexico and their implications on the Oaxaquia concept - Evidence from U-Pb and Lu-Hf isotopes on zirco. Revista Mexicana de Ciencias Geológicas 31 (3), 377-394.

Weber, B., Schaaf, P., Valencia, V.A., Iriondo, A., Ortega-Gutiérrez, F., 2006. Provenance ages of late Paleozoic sandstones (Santa Rosa Formation) from the Maya block, SE Mexico. Implications on the tectonic evolution of western Pangea. Revista Mexicana de Ciencias Geológicas 23 (3), 262-276.

Weber, B., Iriondo, A., Premo, W.R., Hecht, L., Schaaf, P., 2007. New insights into the history and origin of the southern Maya block, SE Me' xico: U-Pb-SHRIMP zircon geochronology from metamorphic rocks of the Chiapas massif. International Journal of Earth Sciences (Geologische Rundschau) 96, 253-269.

Weber, B., Valencia, V.A., Schaaf, P., Pompa-Mera, V., Ruíz, J., 2008. Significance of provenance ages from the Chiapas Massif Complex (Southeastern Mexico): Redefining the Paleozoic basement of the Maya Block and its evolution in a Peri-Gondwana realm. The Journal of Geology 116, 619-639.

Weber, B., Valencia, V.A., Schaaf, P., Ortega-Gutiérrez, F., 2009. Detrital zircon ages from the Lower Santa Rosa Formation, Chiapas: implications on regional Paleozoic stratigraphy. Revista Mexicana de Ciencias Geológicas 26 (1), 260-276.

Weber, B., Scherer, E.E., Schulze, C., Valencia, V.A., Montecinos, P., Mezger, K., Ruiz, J., 2010 $\mathrm{U}-\mathrm{Pb}$ and $\mathrm{Lu}-\mathrm{Hf}$ isotope systematics of lower crust from central-southern Mexico Geodynamic significance of Oaxaquia in a Rodinia Realm. Precambrian Res. 182 (1-2), 149-162. https://doi.org/10.1016/j.precamres.2010.07.007].

Weber, B., Scherer, E.E., Martens, U.K., Mezger, K., 2012. Where did the lower Paleozoic rocks of Yucatan come from? A U-Pb, Lu-Hf, and Sm-Nd isotope study. Chem. Geol. 312-313, 1-17.

Weber, B., González-Guzmán, R., Manjarrez-Juárez, R., Cisneros de León, A., Martens, U. Solari, L., Hecht, L., Valencia, V., 2018. Late Mesoproterozoic to Early Paleozoic history of metamorphic basement from the southeastern Chiapas Massif Complex, Mexico and implications for the evolution of NW Gondwana. Lithos 300-301, 177-179.

Weber, B., Schmitt, A.K., Cisneros-de León, A., González-Guzmán, R., 2019. Coeval Early Ediacaran breakup of Amazonia, Baltica, and Laurentia: Evidence from microbaddeleyite dating of dykes from the Novillo Canyon, Mexico. Geophys. Res. Lett. 46, 2003-2011.

Weber, B., Schmitt, A.K., Cisneros de León, A., González-Guzmán, R., Gerdes, A., 2020. Neoproterozoic extension and the Central Iapetus Magmatic Province in southern Mexico - New U-Pb ages, Hf-O isotopes and trace element data of zircon from the Chiapas Massif Complex. Gondwana Res. 88, xxx.

Yañez, P., Ruíz, J., Patchett, P.J., Ortega-Gutiérrez, F., Gehrels, G.E., 1991. Isotopic studies of the Acatlan complex, southern Mexico: Implications for Paleozoic North American 
tectonics. GSA Bull. 103 (6), 817-828. https://doi.org/10.1130/0016-7606(1991) $103<0817$ :isotac $>2.3$. co; 2 .

Zhao, J., Xiao, L., Gulick, S.P.S., Morgan, J.V., Kring, D., Urrutia-Fucugauchi, J., Schmieder, M., de Graaff, S.J., Wittmann, A., Ross, C.H., Claeys, P., Pickersgill, A., Kaskes, P., Goderis, S., Rasmussen, C., Vajda, V., Ferriere, L., Feignon, J.G., Chenot, E., Perez-Cruz, L., Sato, H., Yamaguchi, K., IODP-ICDP Expedition 364 scientists, 2020. Geochemistry, geochronology and petrogenesis of Maya Block granitoids and dykes from the Chicxulub Impact Crater, Gulf of México: Implications for the assembly of Pangea. Gondwana Res. $82,128-150$.
Zhou, Y., Murphy, M.A., Hamade, A., 2006. Structural development of the PeregrinaHuizachal anticlinorium, Mexico. J. Struct. Geol. 28, 494-507. https://doi.org/ 10.1016/j.jsg.2005.11.005].

Zuffa, G.G., 1985. Optical analyses of arenites: influence of methodology on compositional results. In: Zuffa, G.G. (Ed.), Provenance of Arenites. - NATO ASI Series C, 148: 165189. D. Riedel, Dordrecht. 